\title{
Investigating the human-environment relationship of early intensive salt production: a case study from the Upper Seille Valley, Lorraine, northeast France
}

Article

Accepted Version

Creative Commons: Attribution-Noncommercial-No Derivative Works 4.0

Riddiford, N. G., Branch, N. P., Jusseret, S., Olivier, L. and Green, C. P. (2016) Investigating the human-environment relationship of early intensive salt production: a case study from the Upper Seille Valley, Lorraine, northeast France. Journal of Archaeological Science: Reports, 10. pp. 390-402. ISSN 2352-409X doi:

https://doi.org/10.1016/j.jasrep.2016.10.018 Available at https://centaur.reading.ac.uk/68090/

It is advisable to refer to the publisher's version if you intend to cite from the work. See Guidance on citing.

To link to this article DOI: http://dx.doi.org/10.1016/j.jasrep.2016.10.018

Publisher: Elsevier

All outputs in CentAUR are protected by Intellectual Property Rights law, including copyright law. Copyright and IPR is retained by the creators or other copyright holders. Terms and conditions for use of this material are defined in the End User Agreement. 


\section{www.reading.ac.uk/centaur}

\section{CentAUR}

Central Archive at the University of Reading

Reading's research outputs online 
Full bibliographic details: Journal of Archaeological Science: Reports 10C (2016) pp. 390-402

DOI information: 10.1016/j.jasrep.2016.10.018

Open Access until 31 Dec 2016: https://authors.elsevier.com/a/1U1Q ,rVDBGCj5

\section{Investigating the human-environment relationship of early intensive salt production: A case study from the Upper Seille Valley, Lorraine, northeast France}

Naomi G. Riddiford ${ }^{\text {a,b }}$ (corresponding author), Nicholas P. Branch ${ }^{c}$, Simon Jusseret $^{\mathrm{d}, \mathrm{e}}$, Laurent Olivier ${ }^{\dagger}$ and Christopher P. Green ${ }^{\mathrm{g}}$

aSchool of Archaeology, Geography and Environmental Science, University of Reading, Whiteknights PO BOX 227, Reading, RG6 6AB, UK:

n.g.riddiford@reading.ac.uk

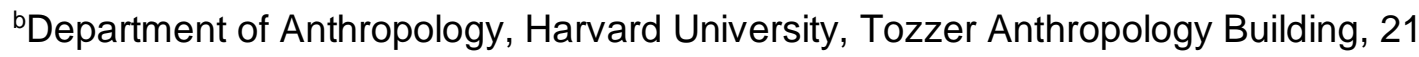
Divinity Avenue, Cambridge, MA 02138, USA: naomiriddiford@fas.harvard.edu; $+17816288396$

'School of Archaeology, Geography and Environmental Science, University of Reading, Whiteknights PO BOX 227, Reading, RG6 6AB, UK:

n.p.branch@reading.ac.uk

dDepartment of Anthropology, The University of Texas at Austin, 2201 Speedway Stop C3200, Austin TX 78712, USA

eUniversité catholique de Louvain, Aegean Interdisciplinary Studies (AegIS-CEMAINCAL), Place B. Pascal 1, boite L3.03.13, 1348 Louvain-la-Neuve, Belgium: simon.jusseret@uclouvain.be

'Musée d'Archéologie Nationale - Domaine National de Saint-Germain-en-Laye, Château-place Charles de Gaulle, 78100 Saint-Germain-en-Laye, France: laurent.olivier@culture.gouv.fr ${ }^{9}$ School of Archaeology, Geography and Environmental Science, University of Reading, Whiteknights PO BOX 227, Reading, RG6 6AB, UK: greenc@waitrose.com

\section{Abstract}

This paper presents the latest findings of multi-disciplinary research into the humanenvironment relationship of intensive Iron Age salt production in the Upper Seille Valley, Lorraine, northeast France. Investigations focus on the early Iron Age workshop "La Digue" ( 625—500 cal BCE; Hallstatt D1—2), where high-resolution 
borehole sampling has been coupled with conventional excavation and geophysical surveying to establish direct linkages between intensive occupation and the alluvial environment of this site. Detailed insights into human-river interactions have been identified, enhancing current understanding of the environmental context and impact of this important early industry. The workshop's palaeogeographic setting has been reconstructed and new evidence for briquetage disposal practices has been identified, confirming that a close relationship existed between salt-making and the local hydrological regime. A large volume of briquetage waste (broken clay-fired saltmaking equipment, ash and charcoal) was dumped into the river at La Digue, causing rapid and deliberate channel blockage, increasing the distance between the workshop and the river. This probably contributed to a localised increase in channel mobility and/or flooding whilst the workshop was active, producing challenging conditions for salt production. The workshop was abandoned following an intense flood event in $\sim 500$ cal BCE, coinciding with a major hydrological shift towards wetter floodplain conditions, likely arising from a combination of natural and anthropogenic factors. This study demonstrates the importance of understanding the environmental context of salt production and the roles of water management and briquetage disposal practices, which have been largely overlooked at other intensive salt making sites that employed the "briquetage technique".

\section{Keywords}

Alluvial environment; Briquetage; Palaeogeography; Palaeohydrology; Salt production; Upper Seille Valley

\section{Introduction}

Salt was an important commodity during later prehistory, and is considered to have brought great power and wealth to those controlling its production and trade (Alexander, 1982; Fawn et al., 1990; Flad et al., 2005; Shotter, 2005). It was, for example, one of the earliest known commodities to be taxed (Tora and Vogel, 1993) and it generated considerable revenue for the Roman Empire: Cities such as Rome flourished due to strategic positions on salt trading routes (Shotter, 2005). There was an enormous increase in the scale of production from the late Bronze Age-early Iron Age onwards, with the emergence of a large number of intensive salt making centres across northwest Europe (Fawn et al., 1990; Harding, 2013; Olivier and Kovacik, 2006) (Figure 1). This has raised important questions about its social and economic implications and the technology involved, which research over the past 
forty years has begun to address (e.g., Alexander, 1982; Alexianu et al., 2011;

Arrowsmith and Power, 2012; de Brissay and Evans, 1975; Fawn et al., 1990;

Fielding and Fielding, 2005; Flad et al., 2009; Harding, 2013; Kinory, 2012; Langouët et al., 1994; Nevell and Fielding, 2005).

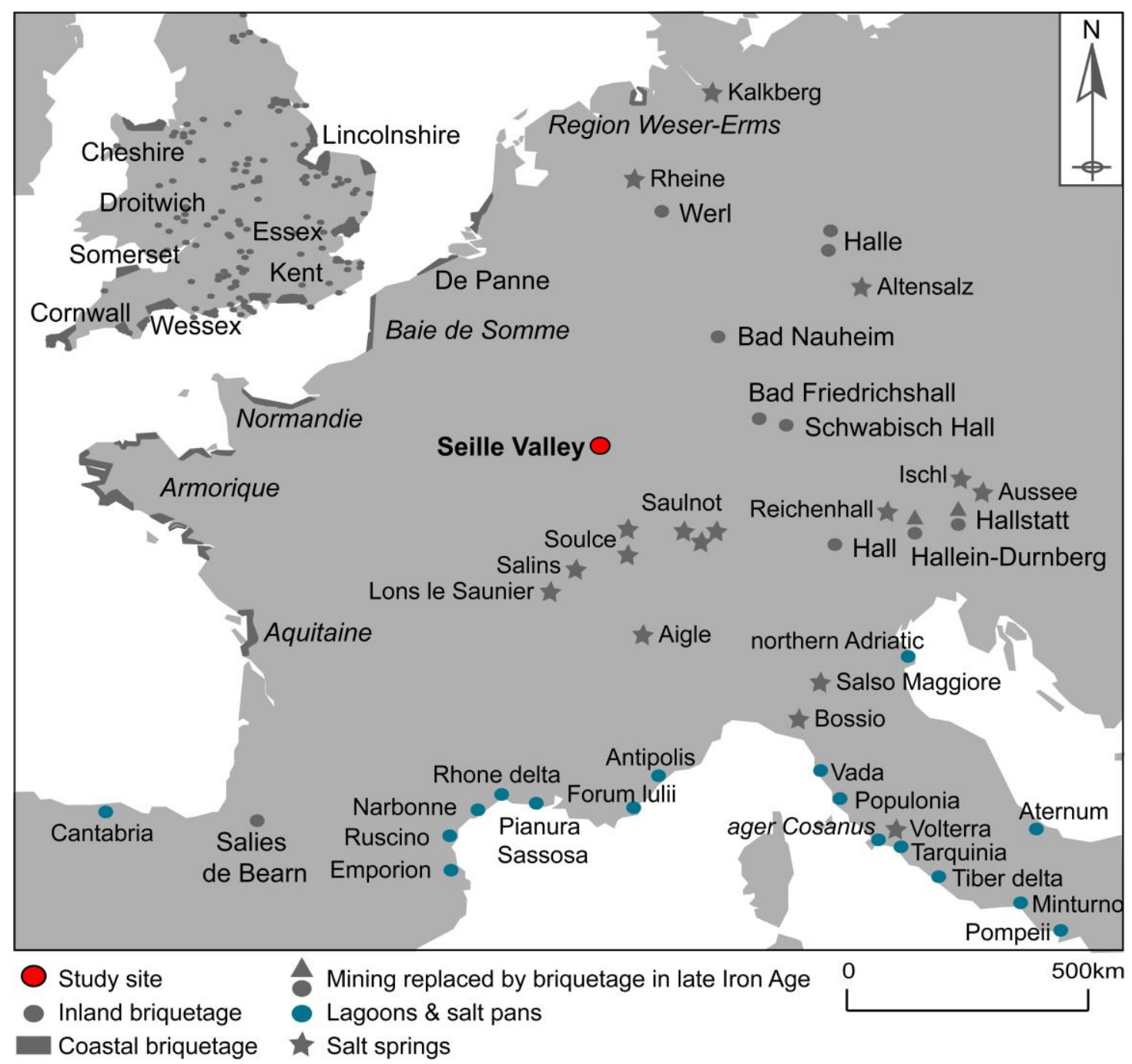

Figure 1: Map of Late Bronze Age, Iron Age and Roman salt-making sites in northwest Europe. Salt was mainly harvested using forced evaporation in furnaces (the "briquetage technique") in northern temperate localities, whilst solar evaporation in lagoons and salt pans was commonly practiced in the Mediterranean region. Redrawn from Harding (2013), Kinory (2012) and Olivier and Kovacik (2006).

This paper focuses on harvesting of salt using the "briquetage technique", involving forced evaporation of saline solutions (derived from brine springs, sea water or saltrich sediments) in furnaces: This was the primary method employed during later prehistory (Biddulph et al., 2012; Harding, 2013). Despite the intrinsic link between salt and the environment, which must have played a key role in the establishment, success and longevity of production at these sites, consideration of the environmental context and impact of salt-making is conspicuously absent in an ever- 
expanding literature, with few exceptions (e.g., Biddulph et al., 2012; Dufraisse and Gauthier, 2002; Grossi et al., 2015; Lane, 2005; Lane and Morris, 2001; Nevell, 2005; Woodiwiss, 1992; ZhiBin, 2008). At best, palaeoenvironmental investigations are typically limited to charcoal and faunal remains recovered during excavation, with virtually no systematic landscape survey coupled with detailed analyses and reconstruction of the environmental history of the immediate and wider area, such as that recommended by Howard et al. (2014). This inevitably limits understanding of site organisation, production activities, environmental impacts, and the implications of natural and/or anthropogenically-induced environmental change for the development and resilience of these intensive production centres.

The overarching aims of the Briquetage de la Seille project are to reconstruct and elucidate the relationship between intensive salt production activities and changes in the natural environment during later prehistory, and to formulate a methodological framework within which to investigate these issues. Research has encompassed long-term Holocene palaeoenvironmental and palaeohydrological change and human occupation of the Upper Seille Valley to establish a baseline against which any environmental changes at the time of, and/or following, establishment of the industry could be assessed and probable causal factors determined (Jusseret et al., 2015; Riddiford et al., 2012). These landscape-scale investigations (described in Riddiford et al., 2012) suggest the industry had a major impact on the area's sedimentological history and hydrological regime. However, the broad spatial and temporal resolution of this initial work limited the extent to which the precise human-environment relationship of salt production could be established. The present research aims to address this issue through the integration of intensive borehole surveying and excavation at a single site, the early Iron Age workshop of "La Digue" (Figures 2 and 3). This approach allows direct linkages to be established between the intense, chronologically confined, occupation of La Digue (covering approximately 125 years, from $\sim 625-500$ cal BC, i.e. Hallstatt D1 -2) and local alluvial environments. The results reveal important new insights into workshop organisation, human-river interactions and probable hydrological impacts of early industrial salt production.

\section{Upper Seille Valley: Archaeological and environmental background}

Archaeological and sedimentological evidence suggest that intensive salt production in the Upper Seille Valley began 600 cal BCE, following a shift from prolonged active river migration and widespread erosion, typical of the region (Notebaert and Verstraeten, 2010), to more stable floodplain conditions and rapid sparsely organic 
silt and clay accumulation (Olivier, 2010; Riddiford et al., 2012): Extensive structural remains of the industry have been identified (Olivier and Kovacik, 2006, 2007) and fluvially-redeposited (sand and gravel-sized) briquetage is consistently recorded for the first time towards the base of a sparsely organic sedimentary unit, signaling that salt production had begun. Alluviation accelerated from this period onwards and the palaeoenvironmental record becomes dominated by evidence for woodland clearance, agriculture and bare/disturbed ground (Riddiford et al., 2012).

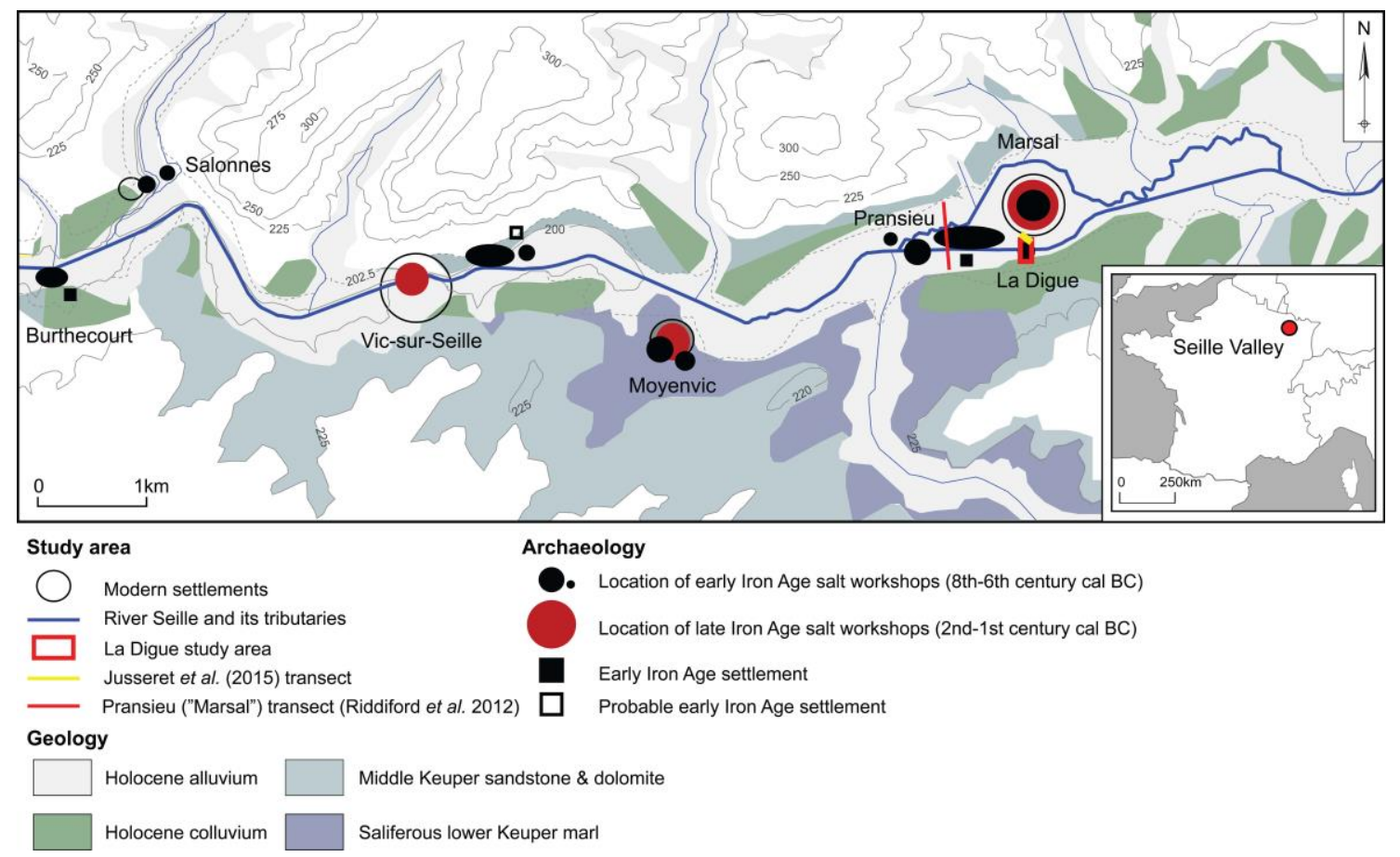

Figure 2: The Seille Valley study area showing the location of the La Digue study area and Marsal ("Pransieu") cross-valley transect discussed in Riddiford et al. (2012). The spatial relationship between the study area, salt archaeology and salt-bearing geology (influencing the distribution of brine springs) is shown. This schematic map is adapted from Goguel (1959), Marchal et al. (1972), Olivier and Kovacik (2006), Riddiford et al. (2012) and Jusseret et al. (2015).

Approximately ten workshops were established on the floodplain between the modern towns of Marsal and Salonnes during the early Iron Age $\left(8^{\text {th }}\right.$ to $6^{\text {th }}$ century cal BCE) (Figure 2). Pollen evidence suggests saltmarsh has been present in this area since at least $\sim 6050$ cal BCE ( 8000 cal BP) (Riddiford et al., 2012) and brine springs are still common. These are related to the local presence of saliferous lower Keuper formations at shallow depth ( 50-80 m) (Baubron et al., 2004), and probably also to groundwater recharge in elevated regions producing resurgences enriched in dissolved salts (Cheval et al., 2004). Historical accounts and recent observations suggest that important and rapid annual and seasonal changes have occurred in the salt concentration of these springs (cf. Baubron et al., 2004; Cheval 
et al., 2004). Watertable height and flood frequency probably also influenced the number and concentration of brine springs over the longer-term.

A large volume of waste (primarily briquetage) totaling around 3-4 million metres ${ }^{3}$ accumulated at salt workshops during the Iron Age, forming mounds up to $12 \mathrm{~m}$ thick and $500 \mathrm{~m}$ in diameter. At the previously studied Pransieu workshop (Figures 2 and 3) (referred to as "Marsal" in Riddiford et al., 2012), blocky (in-situ) and sand and gravel-sized (redeposited) briquetage began accumulating on the surface of a palaeosol radiocarbon dated to 1450-1270 cal BCE (3400-3220 cal BP) (Wk212899): OSL dating suggests this began in the mid-to-late Bronze Age (16401160 cal BCE; $3650-3170$ cal BP (OSL date ML9)), although corroborating archaeological evidence for pre-Iron Age salt production has yet to be identified (Riddiford et al., 2012). The presence of a palaeochannel to the south of the Pransieu workshop has been indirectly inferred from the sediment stratigraphy, whilst late Iron Age palaeochannel deposits (180 cal BCE-50 CE; 2130—1900 cal BP (Wk-21287)) have been identified to the north. It has been hypothesised that briquetage accumulation led to gradual channel blockage and migration, followed by channel abandonment and relocation. This is likely to have impacted on the local hydrological regime and there is pollen evidence for widespread marsh development from 500-250 cal BCE ( 2450-2200 cal BP) onwards (Riddiford et al., 2012).

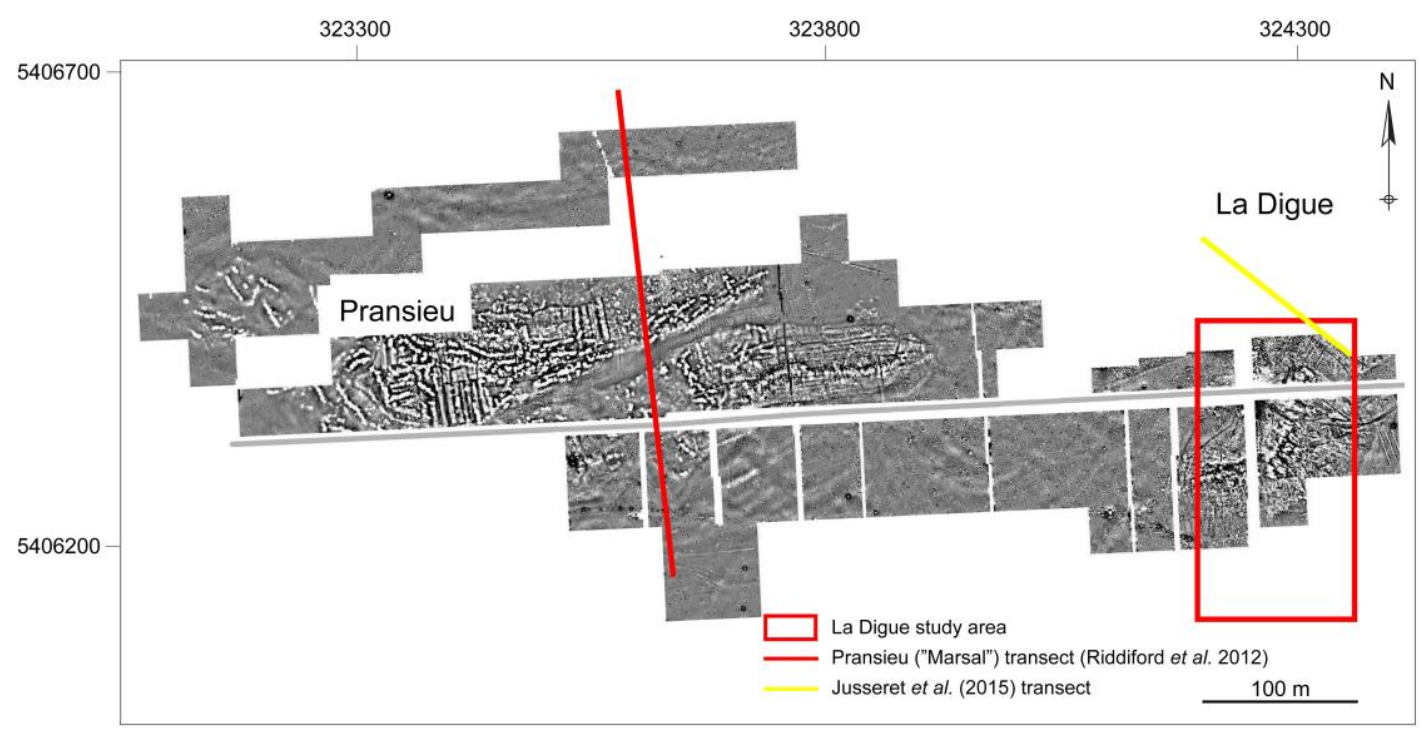

Figure 3: Geophysical survey of the Pransieu and La Digue early Iron Age Workshops, showing the position of the La Digue study area, and borehole transects undertaken at La Digue (Jusseret et al., 2015) and Pransieu (Riddiford et al., 2012). White/black: +/- $5 \mathrm{nT}$, UTM 32N (WGS 84) coordinate system, image courtesy of Posselt \& Zickgraf Prospektionen GbR, Marbourg. 
This occurred during a period of pronounced climatic deterioration, regionallyelevated groundwater and increased flood frequency (Brown, 1997; van Geel et al., 1996; Notebaert and Verstraeten, 2010), which is also likely to have exerted an influence on the hydrological system.

Early Iron Age workshops in the Upper Seille Valley apparently ceased operating by the first half of the $5^{\text {th }}$ century cal BCE, and there is a hiatus in the archaeological record until the second half of the $3^{\text {rd }}$ century cal BCE. What happens during this period is presently unknown: Significantly, archaeological evidence for renewed salt production in the $3^{\text {rd }}$ century cal BCE is characterised by new technologies (small rounded briquetage bars, narrow salt moulds), associated with growth and reorganisation of the industry (Olivier, 2010). Production peaked in the late Iron Age $\left(2^{\text {nd }}\right.$ to $1^{\text {st }}$ century cal BCE), when workshops became focused at Marsal, Moyenvic and Vic-sur-Seille (Olivier and Kovacik, 2006; Olivier, 2010) (Figure 2). The largest briquetage mounds are present at these sites and settlements were probably established on top of the mounds from the Roman period onwards. Although it is likely that the briquetage technique was abandoned at the end of the Iron Age, little is known of salt extraction in the Upper Seille Valley during the Roman period and Early Middle Ages: It is not until the twelfth century that saltworks are regularly mentioned in local historical records (Multhauf, 1978).

The present study focuses on La Digue, a $120 \mathrm{~m} \times 300 \mathrm{~m}$ section of the floodplain immediately south of the village of Marsal (32N 3243905406650 , elevation $202 \mathrm{~m}$ above sea level (m a.s.I.)) (Figure 2). This is essentially a type site for Iron Age salt production in the Upper Seille Valley, having been the subject of archaeological tests in the 1970s (Bertaux, 1972a, 1972b, 1972c, 1976) and detailed investigations by the Briquetage de la Seille project from 2001-2014 (geomagnetic prospections, archaeological tests, systematic excavations) (Olivier, 2000, 2010; Olivier and Kovacik, 2006, 2007; Olivier et al., 2010) (Figure 4a-h). An early Iron Age workshop dating to $\sim 625-500$ cal BCE (Hallstatt D1-2) has been identified at this locality (Olivier, 2014), evident in Figure 3 as a southwest to northeast trending zone of geomagnetic anomalies. Chronology was established using radiocarbon dating of furnace charcoal, and refined using relative dating of briquetage and domestic pottery found in association with archaeological features (Olivier, 2010). Early Iron Age pits, wood-lined storage basins, furnaces, post holes and large quantities of briquetage have been identified during excavation (Figure 4a-d) (Olivier, 2010; Olivier et al., 2010). High-resolution borehole surveying was integral to the 
excavation strategy, making it possible to investigate the precise relationship between salt production and the floodplain environment for the first time. The objectives of the survey were to:

1. Reconstruct the palaeogeographic setting of the La Digue workshop;

2. Establish a clearer understanding of briquetage disposal practices.

The latter has been achieved by determining the spatial relationship between the workshop and the river during the early Iron Age, and assessing whether there is any direct evidence for briquetage channel blockage. The findings are presented here.
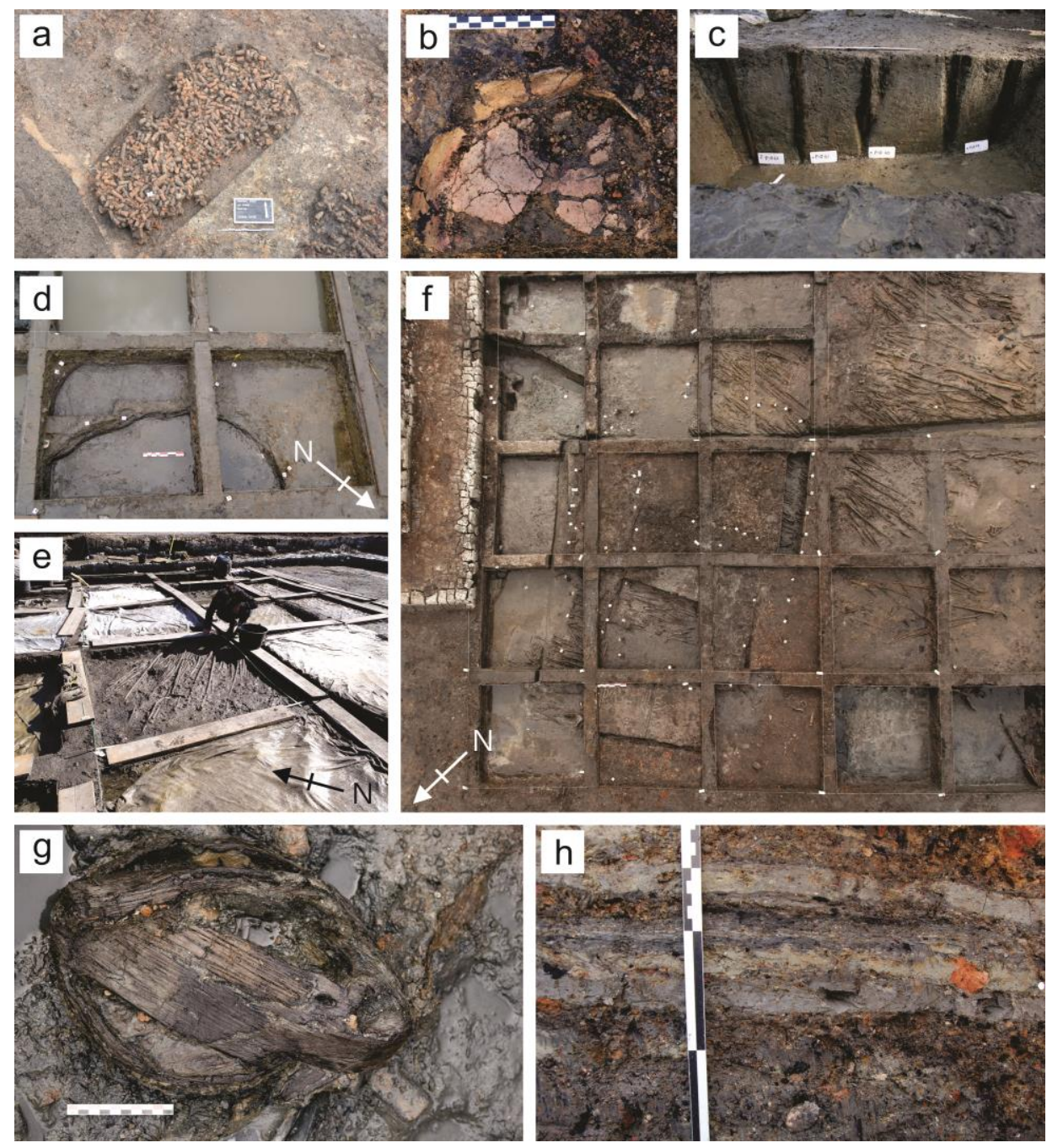

Figure 4: Marsal, La Digue: Early Iron Age (Hallstatt D1-2) remains of salt extraction activities. a: pit containing briquetage debris; b: clay salt mould in situ; c: wooden posts driven in grey silty clay (floodplain) deposits; d: wood-lined basin (settling tank?); e-f: wooden surface exposed at the base of briquetage deposits, resting on grey silty clay (floodplain) deposits; g: remains of wooden bucket, possibly used for brine extraction; h: typical archaeological stratigraphy at La Digue, showing alternation of briquetage deposits (black, orange) and floodplain sediments (grey). 


\section{Method}

Forty-seven boreholes were put down in a series of transects using an Eijkelkamp percussion gouge set powered by an Atlas Copco Cobra TT 2-stroke percussion engine. This was accompanied by targeted coring (ten boreholes) to resolve the position of specific features, such as palaeochannels and briquetage distribution. Spatial attributes were recorded using a Leica Differential Global Positioning System and lithostratigraphy was described in the field using standard procedures for recording unconsolidated sediment (Jones et al., 1999). Surface elevation of each core sample was determined using differential levelling, with reference to the site datum (32N 324271, 5406339; $201.91 \mathrm{~m}$ a.s.I.). Selected core samples were returned to the laboratory at the University of Reading for further description, analyses and radiocarbon dating. The onset of salt production is clearly evident from the widespread occurrence of fluvially redeposited sand and gravel-sized briquetage and charcoal, and blocky in-situ deposits. This stratigraphic marker, together with radiocarbon dating of important stratigraphic horizons, such as occupation deposits, archaeology and channel deposits, was used to reconstruct the early Iron Age floodplain topography at La Digue. Elevation data were converted to raster and inverse-distance-weighted analysis was performed to interpolate between data points using ArcScene GIS version 10.0. Eighteen AMS dates were submitted for radiocarbon dating to Beta Analytic INC, Florida, USA (Table 1). The results were calibrated using OxCal v4.2.3 (Bronk Ramsey, 2009; Bronk Ramsey and Lee, 2013) and the INTCAL13 calibration curve (Reimer et al., 2013). The maximum intercept method was used to calculate date ranges and these are quoted at two-sigma (95.4\%) confidence. Overall, this methodology has permitted a detailed indication of the spatial extent of salt production activities and the sedimentary and human history of this locality.

\section{Results and Interpretation: Lateglacial and Holocene sediment stratigraphy at La Digue}

As we are not focusing on pre-Holocene sediments in this paper, these are only mentioned briefly. A cross-section of the early Iron Age workshop and adjacent floodplain is illustrated in Figure 5, and core samples containing channel deposits are illustrated in Figure 6. The locations of all core samples collected in the study area are shown in Figure 7. 
Table 1: AMS radiocarbon dates obtained from selected borehole core samples at "La

Digue".

\begin{tabular}{|c|c|c|c|c|c|c|c|}
\hline Borehole & $\begin{array}{l}\text { Borehole } \\
\text { surface } \\
\text { elevation } \\
\text { (m a.s.I.) }\end{array}$ & $\begin{array}{l}\text { Sample } \\
\text { elevation } \\
\text { (m a.s.I.) }\end{array}$ & $\begin{array}{l}\text { Radiocarbon } \\
\text { date } \\
\text { (years bp) }\end{array}$ & $\begin{array}{l}\text { Calibrated } \\
\text { age at } 2 \delta \\
\text { range (years } \\
B C E / C E \text { ) }\end{array}$ & $\begin{array}{l}\text { Radiocarbon } \\
\text { laboratory } \\
\text { reference }\end{array}$ & $\begin{array}{l}{ }^{13} \mathrm{C} /{ }^{12} \mathrm{C} \\
\text { ratio (\%o) }\end{array}$ & $\begin{array}{l}\text { Material } \\
\text { dated }\end{array}$ \\
\hline BH52 & 202.04 & $\begin{array}{l}199.58- \\
199.56\end{array}$ & $2920 \pm 40$ & $\begin{array}{l}\text { 1260-1000 } \\
\text { BCE }\end{array}$ & Beta-266133 & -26.6 & $\begin{array}{l}\text { Organic } \\
\text { sediment }\end{array}$ \\
\hline BH52 & 202.04 & $\begin{array}{l}199.48- \\
199.46\end{array}$ & $3160 \pm 40$ & $\begin{array}{l}1510-1300 \\
\text { BCE }\end{array}$ & Beta-266134 & -28.0 & $\begin{array}{l}\text { Organic } \\
\text { sediment }\end{array}$ \\
\hline BH69-L & 201.83 & $\begin{array}{l}200.74- \\
200.72\end{array}$ & $850 \pm 30$ & $\begin{array}{l}1050-1260 \\
C E\end{array}$ & Beta-365359 & -29.0 & $\begin{array}{l}\text { Organic } \\
\text { sediment }\end{array}$ \\
\hline BH69-L & 201.83 & $\begin{array}{l}199.63- \\
199.61\end{array}$ & $2500 \pm 40$ & $\begin{array}{l}\text { 790-490 } \\
\text { BCE }\end{array}$ & Beta-285295 & -27.8 & $\begin{array}{l}\text { Organic } \\
\text { sediment }\end{array}$ \\
\hline BH69-L & 201.83 & $\begin{array}{l}199.46- \\
199.44\end{array}$ & $2380 \pm 40$ & $\begin{array}{l}740-380 \\
\text { BCE }\end{array}$ & Beta-285294 & -25.8 & $\begin{array}{l}\text { Organic } \\
\text { sediment }\end{array}$ \\
\hline BH69-L & 201.83 & $\begin{array}{l}199.18- \\
199.16\end{array}$ & $2420 \pm 40$ & $\begin{array}{l}750-400 \\
\text { BCE }\end{array}$ & Beta-285293 & -26.6 & $\begin{array}{l}\text { Organic } \\
\text { sediment }\end{array}$ \\
\hline BH69-L & 201.83 & $\begin{array}{l}198.71- \\
198.69\end{array}$ & $4770 \pm 40$ & $\begin{array}{l}3640-3380 \\
\text { BCE }\end{array}$ & Beta-285292 & $\begin{array}{l}\text { Not } \\
\text { available }\end{array}$ & $\begin{array}{l}\text { Organic } \\
\text { sediment }\end{array}$ \\
\hline BH69-L & 201.83 & $\begin{array}{l}198.28- \\
198.26\end{array}$ & $5910 \pm 40$ & $\begin{array}{l}4900-4710 \\
\text { BCE }\end{array}$ & Beta-285291 & -25.8 & $\begin{array}{l}\text { Organic } \\
\text { sediment }\end{array}$ \\
\hline BH69-L & 201.83 & $\begin{array}{l}198.05- \\
198.03\end{array}$ & $6720 \pm 40$ & $\begin{array}{l}5720-5560 \\
\text { BCE }\end{array}$ & Beta-285290 & -27.0 & $\begin{array}{l}\text { Organic } \\
\text { sediment }\end{array}$ \\
\hline BH69-L & 201.83 & $\begin{array}{l}197.77- \\
197.74\end{array}$ & $8660 \pm 50$ & $\begin{array}{l}7810-7580 \\
\text { BCE }\end{array}$ & Beta-285288 & -34.2 & $\begin{array}{l}\text { Organic } \\
\text { sediment }\end{array}$ \\
\hline BH69-L & 201.83 & $\begin{array}{l}197.64- \\
197.62\end{array}$ & $9690 \pm 50$ & $\begin{array}{l}\text { 9280-8850 } \\
\text { BCE }\end{array}$ & Beta-285287 & -26.9 & $\begin{array}{l}\text { Organic } \\
\text { sediment }\end{array}$ \\
\hline BH69-L & 201.83 & $\begin{array}{l}197.46- \\
197.43\end{array}$ & $9650 \pm 50$ & $\begin{array}{l}\text { 9250-8840 } \\
\text { BCE }\end{array}$ & Beta-285286 & -27.2 & $\begin{array}{l}\text { Organic } \\
\text { sediment }\end{array}$ \\
\hline BH69-L & 201.83 & $\begin{array}{l}197.19- \\
197.16\end{array}$ & $10,150 \pm 50$ & $\begin{array}{l}\text { 10,100-9550 } \\
\text { BCE }\end{array}$ & Beta-285285 & -31.3 & $\begin{array}{l}\text { Organic } \\
\text { sediment }\end{array}$ \\
\hline BH81-L & 201.57 & $\begin{array}{l}199.95- \\
199.94\end{array}$ & $2480 \pm 30$ & $\begin{array}{l}770-430 \\
\text { BCE }\end{array}$ & Beta-310885 & -26.2 & $\begin{array}{l}\text { Charred } \\
\text { material }\end{array}$ \\
\hline BH88-L & 201.99 & $\begin{array}{l}197.80- \\
197.78\end{array}$ & $3950 \pm 40$ & $\begin{array}{l}\text { 2570-2310 } \\
\text { BCE }\end{array}$ & Beta-310887 & -27.6 & $\begin{array}{l}\text { Organic } \\
\text { sediment }\end{array}$ \\
\hline BH88-L & 201.99 & $\begin{array}{l}197.39- \\
197.35\end{array}$ & $3320 \pm 30$ & $\begin{array}{l}1680-1520 \\
\text { BCE }\end{array}$ & Beta-310888 & -28.3 & Wood \\
\hline BH88-L & 201.99 & $\begin{array}{l}197.15- \\
197.13\end{array}$ & $9930 \pm 50$ & $\begin{array}{l}9660-9290 \\
\text { BCE }\end{array}$ & Beta-310889 & -30.6 & $\begin{array}{l}\text { Organic } \\
\text { sediment }\end{array}$ \\
\hline BH99-L & 202.66 & $\begin{array}{l}197.93- \\
197.89 \\
\end{array}$ & $3510 \pm 40$ & $\begin{array}{l}\text { 1940-1700 } \\
\text { BCE }\end{array}$ & Beta-310890 & -27.7 & $\begin{array}{l}\text { Organic } \\
\text { sediment }\end{array}$ \\
\hline
\end{tabular}

\subsection{Sand and gravel "terrace" (Pleistocene)}

This unit is characterised by light to dark grey and reddish brown silty sandy gravel and sandy clay. The top of this unit is encountered between $5.13 \mathrm{~m}$ and $2 \mathrm{~m}$ below present day ground surface (196.88 m a.s.l. (BH77) to $199.8 \mathrm{~m}$ a.s.I (BH78)), creating a raised sub-surface feature ("terrace") in the east of the study area (Figures 5 and 6). This terrace represents a former (pre-Holocene) stage in the shaping of the valley floor by the river. Inorganic and organic sub-units (containing wood and shell fragments, Mollusca and possible roots) have frequently been identified and 
mottling/Iron staining is common in core samples $\mathrm{BH} 78, \mathrm{BH} 80, \mathrm{BH} 81-\mathrm{L}$ and $\mathrm{BH} 82$, implying oxidation and pedogenesis.

\subsection{Palaeochannel (late Pleistocene-early Holocene)}

This unit is characterised by yellow sand-rich horizons $(\mathrm{BH} 104)$ and light to dark greyish brown or black, occasionally organic, sandy silt and silty clay (BH68; BH69-L; $\mathrm{BH} 77$; $\mathrm{BH} 88-\mathrm{L} ; \mathrm{BH} 100$; $\mathrm{BH} 104 ; \mathrm{BH} 105)$ (Figures 5 and 6 ). It is recorded between $196.88 \mathrm{~m}$ (BH77) and $197.97 \mathrm{~m}$ a.s.I. (BH105). Mollusca and laminated Phragmites stem fragments are common. This has been interpreted as a palaeochannel, radiocarbon dated to between 10,100-9550 cal BCE (Beta-285285) and 7810-7580 cal BCE (Beta-285288) in BH69-L.

\subsection{Alluvium (early to mid-Holocene)}

This unit is characterised by initially dark greyish brown peaty silty clay followed by light and dark grey clay-rich silt in core samples $\mathrm{BH} 68$ and $\mathrm{BH} 69-\mathrm{L}$. It is recorded between $197.51 \mathrm{~m}$ and $198.38 \mathrm{~m}$ a.s.I. in BH68 and between $197.75 \mathrm{~m}$ and $198.74 \mathrm{~m}$ a.s.I. in BH69-L (Figure 5). Small fragments of unidentified woody remains and Phragmites stems are common throughout. This sequence is indicative of channel infilling and abandonment, followed by overbank deposition. It has been radiocarbon dated to between 7810-7580 cal BCE (Beta-285288) and 3640-3380 cal BCE (Beta285292) in BH69-L.

\subsection{Palaeochannel (early to mid-Bronze Age)}

This unit is characterised by very dark grey sandy silt in core samples BH88-L and BH99-L, with frequent gravel in BH88-L (Figure 6). These cores were collected from the west and south of the study area, respectively (Figure 7). This unit is recorded between $4.72 \mathrm{~m}$ (197.27 $\mathrm{m}$ a.s.I.) and $4.21 \mathrm{~m}$ depth (197.78 $\mathrm{m}$ a.s.I.) in BH88-L and between $4.79 \mathrm{~m}$ (197.87 $\mathrm{m}$ a.s.I.) and $4.71 \mathrm{~m}$ depth (197.95 m a.s.I.) in BH99-L (Figure 6). Whole and broken shells, woody remains (up to $2 \mathrm{~cm} \times 1 \mathrm{~cm}$ ) and fine plant matter (Phragmites) are common throughout. Radiocarbon age reversals recorded in BH88-L are probably due to reworking of older sediment under fluvial conditions. A date of 1680-1520 cal BCE (Beta-310888) has been derived from wood (as opposed to organic sediment) at $4.62 \mathrm{~m}$ depth (197.37 m a.s.l.), probably representing the true age of this horizon. In BH99-L, organic sediment at $4.75 \mathrm{~m}$ depth (197.91 m a.s.I.) has been dated to 1940-1700 cal BCE (Beta-310890). These findings suggest a channel was present in the west and south of the study area during the early to mid-Bronze Age. 
ш
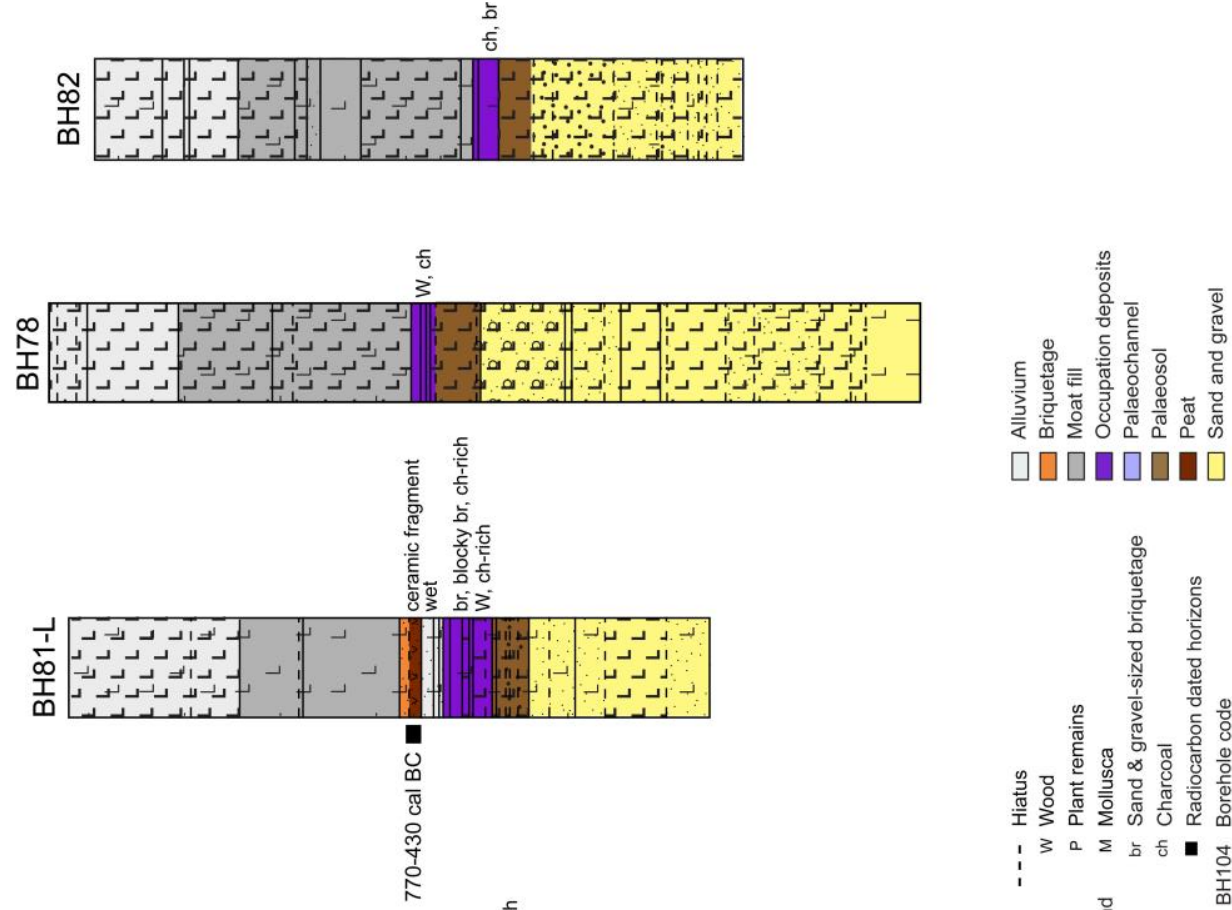

प०००००ण
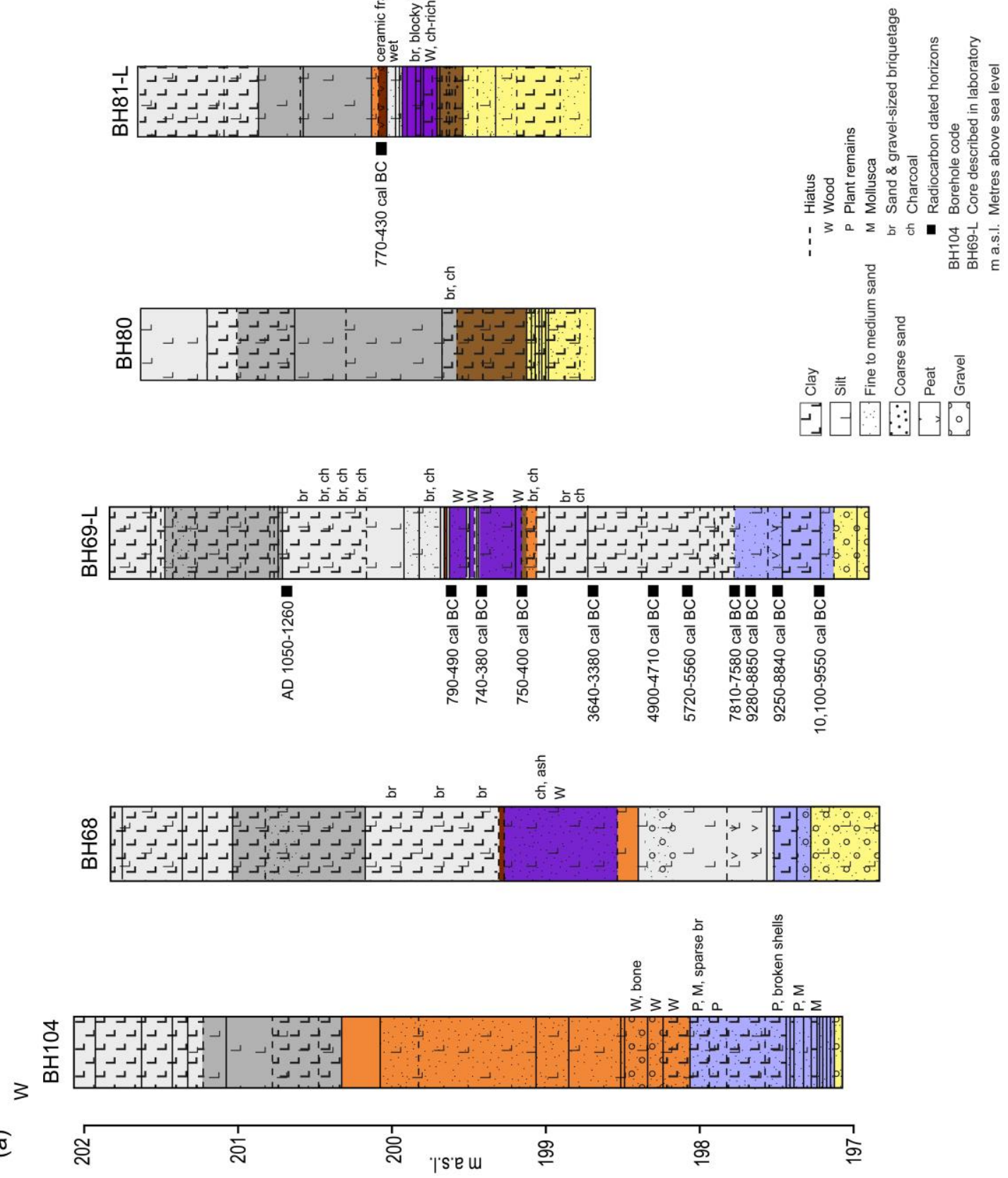

Figure 5(a): La Digue east—west sediment profile. 


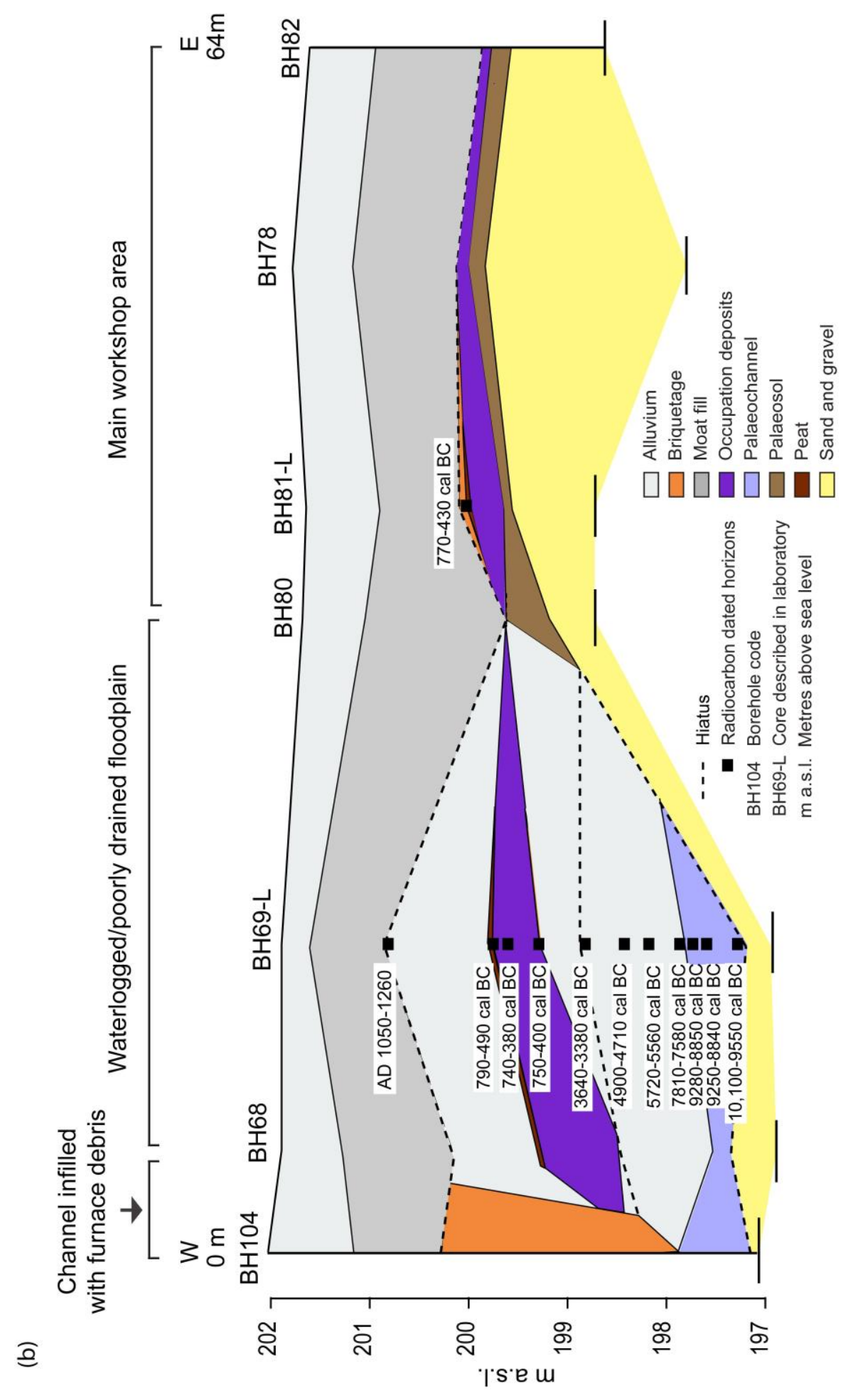

Figure 5(b): Schematic representation of La Digue east-west sediment profile, annotated to highlight features discussed in the text. The transect cuts through the main workshop area, established on a raised sand and gravel "terrace" in the east of the study area adjacent to waterlogged/poorly drained floodplain. A river channel infilled with briquetage is evident in the west of the profile (BH104: See also Figure 6). 


\subsection{Palaeosol (late Bronze Age)}

This unit, which overlies sand and gravel in core samples $\mathrm{BH} 78, \mathrm{BH} 80, \mathrm{BH} 81-\mathrm{L}$ and $\mathrm{BH} 82$, is characterised by mottled dark grey and light grey stiff organic silty clay (Figure 5). It is present between $199.08 \mathrm{~m}$ a.s.l. (BH80) and $199.98 \mathrm{~m}$ a.s.l. (BH78). This unit has also been identified in $\mathrm{BH} 52$ (Table 1; Figure 7), where it has been radiocarbon dated from 1510-1300 cal BCE (Beta-266134) to 1260-1000 cal BCE (Beta-266133). It is thought to represent a palaeosol that developed on raised ground during relatively stable floodplain conditions. Pedogenesis may have extended into the underlying sand and gravel, where common mottling and root channels have been identified (see Section 4.1).

\subsection{Occupation deposits (early Iron Age)}

These comprise several units:

a. A thin layer $(3-9 \mathrm{~cm}$ ) of black charcoal-rich silt and clay overlies the late Bronze Age palaeosol in core samples $\mathrm{BH} 78, \mathrm{BH} 81-\mathrm{L}$ and $\mathrm{BH} 82$ (Figure 5). It is recorded between $199.57 \mathrm{~m}$ (BH81-L) and $200.01 \mathrm{~m}$ a.s.l. (BH78) and has been identified immediately below archaeological features such as furnaces and horizontally-bedded wooden structures during archaeological excavation (e.g., Figure $4 \mathrm{e}-\mathrm{f}$ ). This unit is interpreted as an occupation deposit probably dating to establishment of the workshop. This occupation deposit is absent in BH80 (Figure 5), where dark brown silty clay containing occasional small charcoal and briquetage has instead been recorded (199.63-199.53 $\mathrm{m}$ a.s.l.), suggesting this area of the floodplain was outside the main production zone.

b. Dark grey and black silty clay have been recorded to the west of the palaeosol, between $198.38 \mathrm{~m}$ (BH68) and $199.56 \mathrm{~m}$ a.s.I. (BH69-L) (Figure 5). Fine-grained and blocky briquetage are recorded for the first time in these units, indicating that salt production had begun. Wood is also present (see Section 4.6c). These units are interpreted as poorly drained floodplain peripheral to the main activity zone and in proximity to the channel edge. Sparse, fine-grained briquetage and charcoal were initially deposited in BH69-L, probably under fluvial conditions, followed by blocky briquetage and wood, potentially signaling expansion of workshop activities onto the adjacent poorly drained floodplain.

c. Horizontally-aligned wood-rich horizons have been found in core samples throughout the study area (Figure 7), including those illustrated in Figure 5: BH78 
(200.01-200.09 m a.s.I.); BH81-L (199.56-199.59 m a.s.I.); BH68 (198.15-199.29 m a.s.I.) and BH69-L (199.18 - $199.56 \mathrm{~m}$ a.s.I.). Wood present in core samples from elevated ground in the east of the workshop (e.g., BH78, BH81-L and BH82) probably corresponds to wooden remains found in this area during excavation (Figure $4 \mathrm{e}-\mathrm{f}$ ). These remains have been interpreted as a wood covering (probably brushwood and small branches) laid down to create a stable working surface in the salt extraction zone where settling tanks were located (Figure 7) (Olivier, 2014). The presence of wood in core samples at lower elevation, in proximity to the Iron Age channel (e.g., BH68 and BH69-L), suggests extension of this feature onto wetter areas of the floodplain. Briquetage and charcoal are absent from the wood-rich horizons, implying different depositional conditions to those of the underlying and overlying alluvial units (described in Sections 4.6b and 4.6d, respectively). In BH69-L, wood alternates with fluvial (sand and gravel) and alluvial (clay) sub-units, also containing little or no briquetage and charcoal. This has similarly been recorded in BH66 and BH107, 6 m northeast and 12 m north of BH69-L, respectively (Figure 7). These sub-units have been radiocarbon dated to between $790 \mathrm{cal} B C E$ and $380 \mathrm{cal}$ $\mathrm{BCE}$ in BH69-L. Greater dating precision is not possible due to the radiocarbon plateau, however the archaeological stratigraphy and chronology suggest these horizons are contemporary with the workshop.

d. Wood-rich horizons are overlain by blocky briquetage and organic silty clay rich in briquetage, charcoal and ash between $199.6 \mathrm{~m}$ and $199.99 \mathrm{~m}$ a.s.l. in BH81-L (Figure 5). The sediment becomes increasingly sandy upwards and black peaty sandy silt containing a briquetage vessel sherd is recorded at $199.89-199.95 \mathrm{~m}$ a.s.I. This unit has been radiocarbon dated to 770-430 cal BCE (Beta-310885). Dark brown herbaceous peat and peaty silt have similarly been recorded above blocky briquetage in BH68 (Section 4.6b) and clay-rich silt in BH69-L (Section 4.6c), between $199.31-199.37 \mathrm{~m}$ a.s.I. and 199.67-199.675 m a.s.l., respectively.

\subsection{Briquetage channel fill (early Iron Age)}

This unit is present in cores $\mathrm{BH} 77, \mathrm{BH} 97, \mathrm{BH} 99-\mathrm{L}, \mathrm{BH} 100, \mathrm{BH} 104$ and $\mathrm{BH} 105$ (Figure 6) and is characterised by very dark greyish black sandy silt and gravel containing increasing amounts of fine-grained and blocky briquetage and charcoal, and compacted sub-units of reddish-orange blocky briquetage. Large isolated fragments of horizontally-bedded wood $(6 \mathrm{~cm} \times 1 \mathrm{~cm})$ and bone $(4 \mathrm{~cm} \times 3 \mathrm{~cm})$ have been recorded toward the base of the unit in $\mathrm{BH} 104$ (Figures 5 and 6). Briquetage channel fill has been recorded between $197.56 \mathrm{~m}$ a.s.I. (BH77) and $201.64 \mathrm{~m}$ a.s.I. 

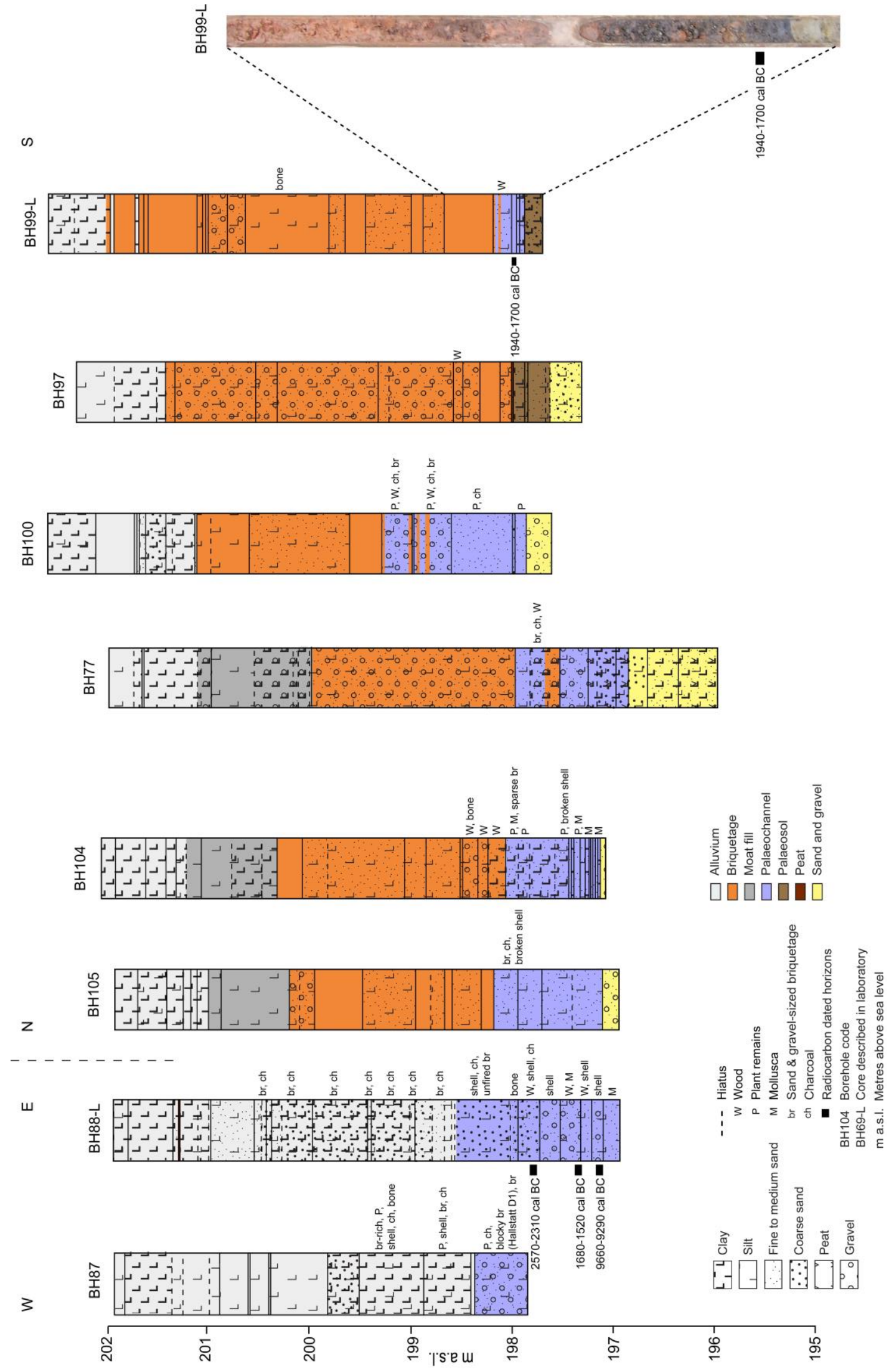

Figure 6: La Digue core samples containing evidence for early Iron Age channel deposits and in-channel briquetage accumulation. These cores have been used to determine the approximate location of the early Iron Age river thalweg, illustrated in Figure 7. 
(BH99-L), and this unit ranges in thickness from $2.37 \mathrm{~m}$ (BH104) to $3.69 \mathrm{~m}$ (BH99-L). The briquetage has been typologically dated to the early Iron Age (Hallstatt D1), from the same period as the La Digue workshop. These results suggest the presence of a north-south orientated river channel, which became infilled with briquetage whilst the workshop was active. Common fine-grained and sparse blocky (Hallstatt D1) briquetage (BH87), charcoal, bone and wood (BH88-L) have also been identified in palaeochannel deposits to the west of the workshop (Figure 6). It is therefore likely that a second east-west orientated branch of the river was present during this period (Figure 7), which was unaffected by channel blockage.

\subsection{Alluvium (post-Iron Age)}

This unit is characterised by dark brown silty clay containing occasional decomposed plant matter and redeposited fine-grained briquetage and charcoal. Isolated fragments of blocky briquetage are also present, probably due to sediment disturbance associated with post-Iron Age development and fortification of Marsal village. It is recorded between $199.37 \mathrm{~m}$ and $200.75 \mathrm{~m}$ a.s.I. in cores BH68 and $\mathrm{BH} 69-\mathrm{L}$ (Figure 5), and the top of this unit has been radiocarbon dated to 1050-1260 CE (Beta-365359) in BH69-L. It is absent in other core samples due to a hiatus (visible as a sharp, erosional contact) caused by construction of a moat in 1699 (see Section 4.9).

\subsection{Moat fill (post-17 ${ }^{\text {th }}$ Century)}

This unit is characterised by soft, mottled light and dark grey, silt and clay containing varying amounts of laminated plant remains (Phragmites stems), decomposed plant matter, whole and broken shells and sand-sized briquetage. It is recorded in all core samples in the northeast of the study area, north of (and including) BH77 (Figure 7). It is therefore present in all of the sediment logs in Figure 5, where it occurs between $199.63 \mathrm{~m}$ (BH80) and $201.34 \mathrm{~m}$ (BH69-L) a.s.l. This moat was constructed during fortification of Marsal village in 1699 CE.

\subsection{Alluvium (modern)}

This unit is characterised by stiff dark greyish brown clay containing modern roots and common sand-sized briquetage. Redeposited blocky briquetage is also present due to recent sediment disturbance. This pedogenically altered alluvium is recorded between $200.57 \mathrm{~m}$ (BH81-L) and $202.66 \mathrm{~m}$ a.s.I. (BH99; BH100) (Figures 5 and 6). 
Elevation ( $m$ a.s.I.)

$197.56-197.94$

$197.94-198.31$

$198.31-198.69$

$198.69-199.06$

$199.06-199.44$

$199.44-199.81$

$199.81-200.19$

$200.19-200.56$

$200.56-200.94$

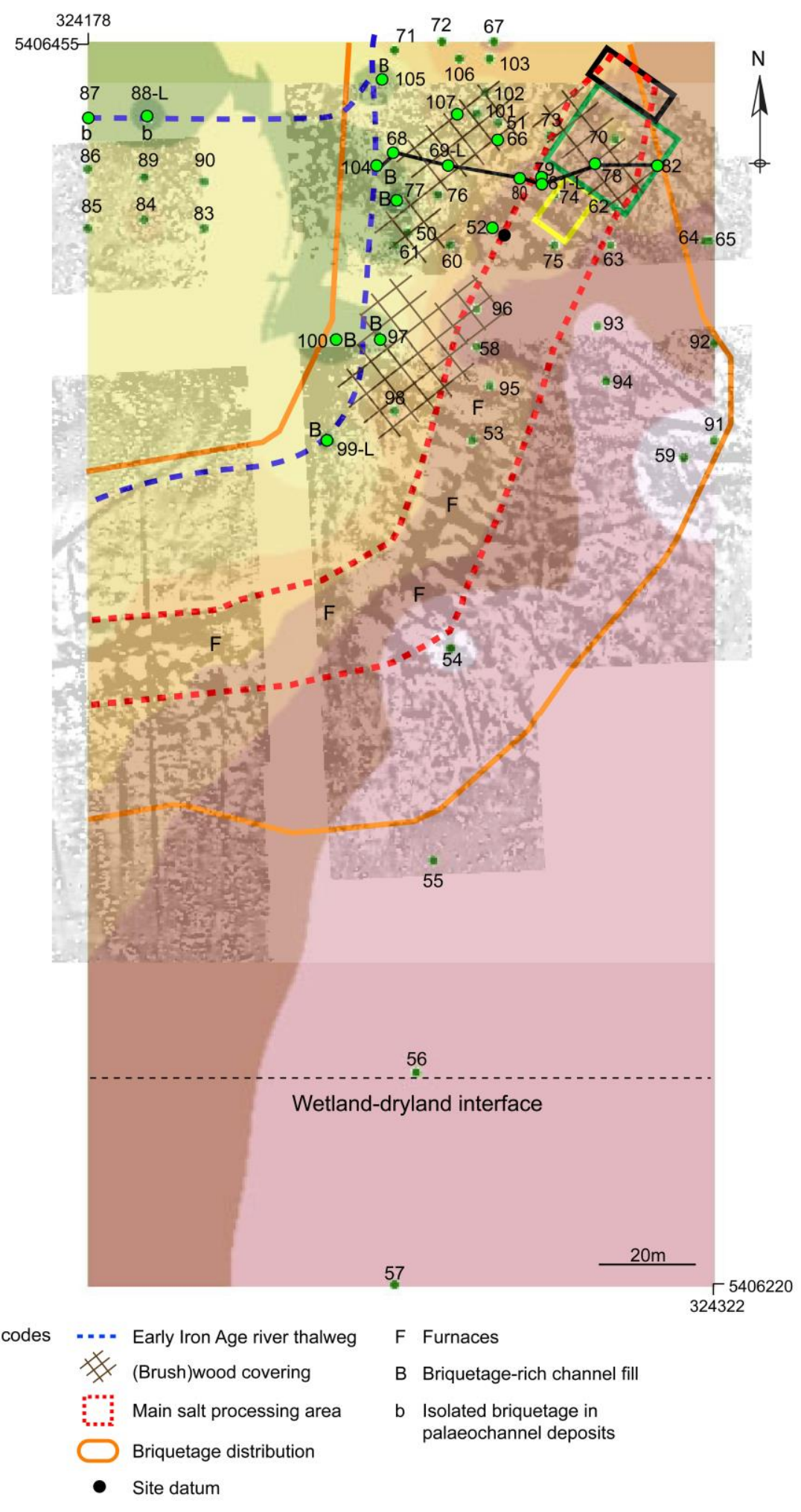

Figure 7: Topographic reconstruction of the base of Iron Age deposits and schematic map of the La Digue workshop area, overlain on geophysical survey results shown in Figure 3. White/black: +/- 5 nT, UTM 32N (WGS 84) coordinate system. Notable features identified as a result of excavation, borehole sampling, and the geophysical survey are illustrated. 


\section{Discussion}

\subsection{Environmental context of salt production in the Upper Seille Valley}

It has been possible, based on these results, to reconstruct the palaeogeographic setting of the La Digue workshop and to establish a much clearer understanding of briquetage disposal practices and the relationship between the river and the workshop than has previously been achieved. The findings are as follows.

\subsubsection{Palaeogeographic setting}

The reconstructed early Iron Age topography and palaeogeographic setting of the La Digue workshop are illustrated in Figure 7 . The results suggest a river has been present in the northwest of the study area since the Late Pleistocene, incising the Pleistocene sand and gravel and creating a northwest dipping land surface, with a raised sand and gravel "terrace" in the east. The lower part of the floodplain represents a pre-Holocene episode of erosional down-cutting from the level of the terrace, and subsequent Holocene aggradational infill of the depression created by this down-cutting. A river continued to be present in the study area into the Bronze Age and early Iron Age periods, with two branches identified in the borehole survey: North—south and east-west. The approximate location of the early Iron Age channels is illustrated in Figure 7. Findings from the borehole survey and excavation indicate that the La Digue workshop was established on raised ground adjacent to the north-south channel in $~ 625$ cal BCE (Figure 7) (Olivier, 2010). Activity took place on the surface of a late Bronze Age palaeosol (1510-1300 cal BCE (Beta266134) to 1260-1000 cal BCE (Beta-266133)) (199.1-200 m a.s.I.), which is likely to have formed under relatively dry stable conditions. This locality was probably selected for the workshop because it was above the maximum flood level (hence palaeosol development) and the substrate was naturally well-draining, providing dry conditions essential for salt production in an otherwise poorly drained environment. These findings are directly comparable to those from Pransieu, where salt production became established on a contemporary palaeosol (1450 - 1270 cal BCE; 34003220 cal BP (Wk-212899)) (198.2-200 m a.s.l.), overlying Pleistocene sand and gravel terraces (Riddiford et al., 2012). These locational characteristics are therefore probably typical of early Iron Age workshops in the Upper Seille Valley.

Waterlogged/poorly drained floodplain has been identified on lower ground peripheral to the main activity zone at La Digue (Figure 7) and the presence of fluviallyredeposited briquetage and charcoal in the sedimentary sequence suggests flooding took place whilst the workshop was active. This was followed by expansion of 
activities onto the poorly drained floodplain, evident from accumulation of blocky insitu briquetage and construction of a (brush)wood covering. Briquetage and wood were probably used to create a stable working surface on otherwise waterlogged ground. The (brush)wood covering appears to have extended down slope from the north of the workshop onto the poorly drained floodplain, where it then ran parallel to the north—south channel (Figure 7). It was therefore probably used to provide access between the workshop and the river.

\subsubsection{Briquetage disposal practices and consequences}

Briquetage distribution at La Digue has been inferred from the presence/absence of briquetage in the sedimentary record and from geomagnetic prospection (Figure 7). It provides a crude indication of the spatial extent of workshop activities. The most significant finding from this site is the presence of thick accumulations of anthropogenic debris (primarily briquetage) in and overlying early Iron Age palaeochannel deposits, offering a much clearer understanding of briquetage disposal practices during the initial phase of this industry than has hitherto be achieved. It provides clear evidence for channel infilling, initially hypothesised from indirect sedimentary evidence at Pransieu (Riddiford et al., 2012). Overall, these findings imply it may have been common practice to dispose of briquetage and associated salt production waste into the river at early Iron Age workshops. This would explain the widespread distribution of sand and gravel-sized briquetage in the sedimentary record.

At La Digue, these accumulations are particularly evident in the north—south channel, and the density and thickness of the debris, contemporary with the workshop, suggest rapid and deliberate channel blockage. This coupled with the presence of an artificial (brush)wood surface adjacent to the channel highlight an important and previously unrecognised relationship between the workshop and the river. Briquetage may have been used to stablise the river bank, providing access to the channel, possibly for navigation. However, subsequent channel blockage would have prevented long term use of the river for this purpose. Alternatively, salt workers may have attempted to divert flow to the east-west channel, which appears to have passed to the north of the workshop (Figure 7). This may have been done with the intention of expanding activities onto lower, poorly draining, parts of the floodplain and/or reducing flood risk by increasing the distance of the workshop to the river. Jusseret et al. (2015) have found supporting evidence for northward migration of the river during this period: Palaeochannel deposits have been identified across a 150 
$\mathrm{m}$ stretch of the floodplain, beginning in the northeast of the La Digue study area and extending towards Marsal village (the location of this transect is illustrated in Figures 2 and 3). Early Iron Age briquetage has been identified in these deposits at La Digue, whilst late Iron Age briquetage has been found near Marsal, corresponding to the known locations of early and late Iron Age salt workshops, respectively (Olivier and Kovacik, 2006). These results suggest that significant channel migration occurred during the Iron Age, and this was potentially influenced by briquetage disposal and associated river management. As hypothesised at Pransieu (Riddiford et al., 2012), channel blockage is likely to have considerably disrupted the fluvial regime, probably triggering increased flood frequency and waterlogging, making it extremely difficult to sustain salt production over the long term. Greater sediment input from catchmentwide soil erosion (arising from intensive salt production, agriculture and deforestation (Riddiford et al., 2012)) is also likely to have further lowered the channel capacity, thereby contributing to increasing flood frequency. The fluvial response was probably exacerbated by pronounced climatic deterioration, elevated groundwater and heightened flood intensity that affected the region in $~ 800-500$ cal BCE (Notebaert \& Verstraeten, 2010; Zolitschka et al., 2003), increasing sensitivity of the Upper Seille Valley hydrological system to disturbance.

New findings from La Digue provide localised evidence for increased channel mobility and/or flooding whilst the workshop was active, probably arising (at least partially) from in-channel briquetage disposal. Alternating horizons of natural alluvium and (brush)wood could imply periodic abandonment of activities along the channel edge, followed by reoccupation, in response to variable channel conditions. This could potentially be related to either seasonal (spring/summer) production to avoid winter flooding, or longer periods of abandonment due to increased flood frequency and intensity, which eventually led to permanent abandonment in 500 cal BCE. Workshop activity at La Digue appears to have ended following a major flood event, after which peat developed, implying impeded drainage. This has been archaeologically dated to $\sim 500$ cal BCE (Olivier, 2014) and potentially corresponds to the onset of widespread marsh development in the Upper Seille Valley, inferred from a rapid and sustained increase in Cyperaceae pollen that began in $\sim 500-250$ cal BCE (2450-2200 cal BP) (Riddiford et al., 2012). This reflects a major hydrological shift towards wetter floodplain conditions, probably resulting from a combination of natural and anthropogenic factors. Valley-wide workshop abandonment by the early $5^{\text {th }}$ century cal BCE could have occurred in response to development of a more dynamic floodplain environment, with increased river mobility, waterlogging and 
inundation, potentially accompanied by a reduction in the number and concentration of brine springs. Nevertheless, socio-political changes (suggested by the simultaneous collapse of early Iron Age "princely" centres throughout northwest Europe) cannot be discounted (cf. Olivier, 2000). Salt-making activities were subsequently relocated to Marsal, Moyenvic and Vic-sur-Seille (Figure 2), where substantial briquetage deposits accumulated, forming artificial "islands" on the floodplain. Production took place on these features, raising workshops above waterlogged ground. This probably facilitated expansion and intensification of the industry in an otherwise potentially unfavourable environment.

\subsection{Wider implications}

Review of the literature suggests there are notable similarities between geographical characteristics and transformation of the Upper Seille Valley from a natural to cultural landscape with those of other early inland and coastal salt-making sites dating from the Bronze Age to Roman periods (Figure 1) (e.g., Bell et al., 1999; Bradley, 1992; de Brisay and Evans, 1975; Fawn et al., 1990; Flad et al., 2009; Lane and Morris, 2001; Nevell and Fielding, 2005; Went, 2011; Woodiwiss, 1992). These sites are also likely to have been influenced by pronounced climatic deterioration and hydrological (including relative sea level) changes occurring throughout northwest and central Europe at this time (e.g., Biddulph et al., 2012; Bradley, 1992; Fawn et al., 1990; Healey, 1999; Lane and Morris, 2001; Went, 2011). Together, this highlights the importance of understanding the environmental context of these sites and raises important questions for future research.

Inter-site comparisons clearly indicate a close relationship between salt production and hydrology: Workshops were typically located in wetland environments in proximity to salt source and water courses (rivers, tidal channels) (Bradley, 1992; Connelly and Power, 2005; Dodds, 2005; Fawn et al., 1990; Flad et al., 2009; Garner, 2005; Healey, 1999; Kinory, 2012; Kleinmann, 1975; Lane, 2005; Nevell, 2005; Tessier, 1975; Thoen, 1975; Went, 2011; Woodiwiss, 1992). As in the Upper Seille Valley, these sites were inherently vulnerable to waterlogging and flooding, conflicting with the essential need for dry conditions to prevent dilution of brine solutions, dousing of furnace fires and re-hydration of salt crystals (Connelly and Power, 2005; Fawn et al., 1990; Gurney, 1999; Nevell, 2005; Fielding, 2005;

Woodiwiss, 1992). Nevertheless, it was not uncommon for production to continue for hundreds of years (e.g., Jülich, 2005; Lane, 2005; Martin, 1975; Nevell, 2005; Thoen, 1975; Woodiwiss, 1992). The approaches taken to mitigate the threat of flooding in 
the Upper Seille Valley were probably widely adopted: Findings from La Digue suggest that subtle differences in topography and relative vulnerability of areas to waterlogging and flooding influenced site organisation, possible seasonal production, and allocation of activity zones. These zones are characteristic features of early intensive salt-making sites (e.g., Arrowsmith and Power, 2012; Connelly and Power, 2005; Flad et al., 2009; Gurney, 1999; Jülich, 2005; Lane, 2005; Woodiwiss, 1992). Salt extraction and processing activities seem to have typically been restricted to naturally-elevated well-draining ground and/or areas protected by natural flood barriers, such as levees and coastal dunes (e.g., Fawn et al., 1990; Garner, 2005; Kleinmann, 1975; Kondo, 1975; Thoen, 1975; Went, 2011; Woodiwiss, 1992). Woodlined ditches were often used to transport brine from source to processing areas (e.g., Arrowsmith and Power, 2012; Dodds, 2005; Garner, 2005; Gurney, 1999; Lane, 2005; Woodiwiss, 1992) and it has been suggested at a small number of sites that ditches were used to drain marginal areas to create suitable conditions for salt production, implying water management (Garner, 2005; Woodiwiss, 1992). This practice may have been more widespread than is currently recognised.

It seems that briquetage was commonly used to create stable working surfaces on waterlogged ground, allowing expansion of workshop areas (e.g., Biddulph et al., 2012; Healey, 1999; Flad et al., 2009; Garner, 2005; Went, 2011; Woodiwiss, 1992). In the Upper Seille Valley this has been shown to include in-channel briquetage disposal and anthropogenically-induced channel migration, which (coupled with naturally deteriorating environmental conditions) had unintended, yet inevitable, hydrological consequences that potentially contributed to permanent site abandonment. Waste disposal on the edges of, and into, water courses (ditches, rivers and tidal creeks) has also been noted at a small number of other salt workshops, where it has been linked in some cases to site expansion and/or land reclamation. However, this has received little more than a passing comment: Sites include Chidham (West Sussex, UK) (Bradley, 1992); Helpringham Fen (Lincolnshire, UK) (Healey, 1999); the Wash (East Anglia, UK) (Went, 2011); Stanford Wharf (Essex, UK) (Biddulph et al., 2012); and Zhongba (Chongqing City, China) (Flad et al., 2009; ZhiBin, 2008). Given the proximity of salt-making sites to water courses and the large volume of waste produced by this activity, it is feasible that briquetage entered the fluvial environment more often than has currently been documented. The likely hydrological implications of this, highlighted by findings from the Upper Seille Valley, emphasises the importance of investigating this further. Using briquetage to artificially raise working surfaces may also have been a common adaptation to 
increasingly wet conditions: Workshops have frequently been identified on top of briquetage deposits, although these are smaller than the late Iron Age mounds identified in the Upper Seille Valley (Bestwick, 1975; Biddulph et al., 2012; Dodds, 2005; Fawn et al., 1990; Flad et al., 2009; Healey, 1999; Kondo, 1975; Lane, 2005; Went, 2011; Woodiwiss, 1992). This practice is potentially analogous to coastal and riverine "dwelling mounds" in Germany and the Netherlands, constructed from the early Iron Age onwards to provide protection to settlements during episodes of severe flooding (e.g., van Geel et al., 1998; Meier, 2004; Schepers et al., 2013). Further research is however required to test this hypothesis.

Many coastal and inland salt-making sites were abandoned and subsequently buried by sediment when increased flooding could no longer be successfully mitigated, socio-political structures sustaining salt production activities collapsed, and/or new salt production technologies arose and changed. Added to this is the possible (and important) impact of hydrological changes on brine availability at inland sites, which has yet to be investigated in this context. Increased flooding has primarily been attributed to regional alterations in the hydrological regime triggered by climate change, rising relative sea level and human activities such as agriculture and associated woodland clearance (e.g., Biddulph et al., 2012; Bradley, 1992; Fawn et al., 1990; Gurney, 1999; Healey, 1999; Lane, 2005). However, the findings presented here suggest that salt-making activities may also have significantly contributed to this, through modification of the local hydrological regime, and increased sediment supply as a result of environmental disturbance at workshops (e.g., soil erosion) and in the wider landscape (e.g., fuel utilisation leading to deforestation) (Dufraisse, 2002; Dufraisse and Gauthier, 2002; Lane and Morris, 2001; Pétrequin et al., 2001; Riddiford et al., 2012). The palaeoenvironmental context of these sites therefore deserves more attention, due to new insights this can offer into human-environment interactions and consequences of early intensive salt production.

\section{Conclusion}

High-resolution borehole sampling coupled with conventional excavation and geophysical surveying has built on and refined previous investigations described in Riddiford et al. (2012). It has enabled the palaeogeographic setting of early Iron Age salt production activities at La Digue to be established and detailed insights into human-river interactions to be identified, enhancing current understanding of this important early industry. It has permitted detailed reconstruction of the local landscape and identification of changes in the floodplain environment directly related 
to salt-making, which would not have been possible otherwise. Establishing a natural baseline of hydrological and environmental changes prior to the onset of salt production was pivotal to determining this. The findings presented here suggest there was deliberate use of the landscape to the benefit of salt production (with unintended consequences) and that a close relationship existed between salt-making and the local hydrological regime. Water management was probably integral to this activity in the Upper Seille Valley, raising important questions about the extent to which this was practiced at other salt-making sites and how it affected hydrology, particularly during periods of climatic change when there was heightened environmental sensitivity to human disturbance. These findings also draw attention to the importance of understanding briquetage disposal practices, which have been largely overlooked elsewhere. The enormous quantity of waste generated by the briquetage technique had the potential to significantly alter the environment and landscape of salt production sites. These impacts were probably more widespread than is currently recognised given the large number and scale of salt-making sites from the Iron Age onwards. As such, we would argue that the environmental context and implications of this activity are equally worth considering alongside currently prevailing technological, social and economic questions. Moreover, there is clearly a need to extend geoarchaeological investigations of human interactions with, and impacts on, river systems (including floodplain exploitation and management of water resources) to encompass early intensive salt production.

\section{Acknowledgements}

The authors are grateful for support received from the Département de la Moselle, Ministère de la Culture (Direction des Patrimoines), Parc naturel régional de Lorraine and the Marsal community. S.J. acknowledges financial support from the Belgian F.R.S.-FNRS through a postdoctoral research scholarship (2011-2015). We would also like to thank Kevin Williams, Robert Batchelor and Daniel Young (University of Reading) for fieldwork and laboratory assistance.

\section{References}

Alexander, J.A., 1982. The prehistoric salt trade in Europe. Nature 300, 577-578.

Alexianu, M., Weller, O., Brigand, R., Curcă, R-G., Cotiugă, V., Moga, I., 2011. Salt Springs in Today's Rural World: An Ethnoarchaeological Approach in Moldavia (Romania), in: Alexianu, M., Weller, O., Curcă, R-G. (eds.), Archaeology and Anthropology of Salt: A Diachronic Approach. Proceedings of the International 
Colloquium, 1-5 October 2008. BAR International Series 2198, Archaeopress, Oxford, 7-24.

Arrowsmith, P., Power, D., 2012. Roman Nantwich: A Salt-Making Settlement. BAR British Series 557, Archaeopress, Oxford.

Baubron, J.- C., Bourgeois, B., Feuga, B., Fourniguet, G., Le Nindre, Y.- M., NguyenThe, D., Quesnel, F. (with the collaboration of Carnus, E., Catimel, S., Cheval, L. Coutelle, A., Delpont, G., Lopez, B., Marchetto, M., Olivier, L., Perrin, J., Poly, D., Roettger, B., Thomaidis, C.), 2004. Étude de l'aléa lié à la dissolution du sel dans le bassin de Dieuze - Château-Salins et incidences sur les aquifères et sur les mouvements de la surface du sol. Rapport final, BRGM/RP-52535-FR.

Bell, A., Gurney, D., Healey, H., 1999. Lincolnshire salterns: Excavations at Helpringham, Holbeach St. Johns and Bicker Haven, East Anglian Archaeology Report no.89. Heritage Trust of Lincolnshire.

Bertaux, J.P. 1972a. Le Briquetage de la Seille. Sondages à Marsal (Moselle). Quelques observations archéologiques et géologiques. Bulletin de l'Académie et Société lorraines des Sciences XI(3), 219-228.

Bertaux, J.P. 1972b. Le Sel et la Lorraine. Bulletin de l'Ingénieur des Industries Chimiques 68, 9-23.

Bertaux, J.P. 1972c. Le Briquetage de la Seille. La reprise des fouilles archéologiques (cinq années d'activité 1967-1971). Fiches d'Information des Amis de l'Archéologie mosellane 3-4, 333-343.

Bertaux, J.P. 1976. L'archéologie du sel en Lorraine. "Le Briquetage de la Seille" (état actuel des recherches), in: Millotte, J.P., Thevenin, A. And Chertier, B.(eds.), Livret guide de l'excursion A7 Champagne, Lorraine, Alsace, FrancheComté. 9éme Congrès de l'Union Internationale des Sciences Préhistoriques et Protohistoriques. Éditions du CNRS, 67-79.

Bestwick, J.D., 1975. Romano-British inland salting at Middlewich (salinae), Cheshire, in: de Brisay, K.W., Evans, K.A. (eds.), Salt: The study of an ancient industry. Colchester Archaeology Group, Colchester, 66-70.

Biddulph, E., Foreman, S., Stafford, E., Stansbie, D., Nicholson, R., 2012. London Gateway: Iron Age and Roman salt making in the Thames Estuary: Excavation at Stanford Wharf Nature Reserve, Essex. Oxford Archaeology Monograph 18. Bradley, R., 1992. Roman Salt Production in Chichester Harbour: Rescue Excavations at Chidham, West Sussex. Britannia 23, 27-44. de Brisay, K.W., Evans, K.A. (eds.), 1975. Salt: The study of an ancient industry. Colchester Archaeology Group, Colchester. 
Bronk Ramsey, C., 2009. Dealing with outliers and offsets in radiocarbon dating. Radiocarbon 51(3), 1023-1045.

Bronk Ramsey, C., Lee, S., 2013. Recent and planned developments of the program Oxcal. Radiocarbon 55(2-3), 720-730.

Brown, A.G., 1997. Alluvial Archaeology: Floodplain archaeology and environmental change. Cambridge University Press, Cambridge.

Cheval, L., Marchetto, M., Poly, D., Feuga, B., 2004. Cartographie de la répartition du sel dans les eaux de surface du bassin de Dieuze - Château-Salins. Résultats des campagnes de mesure de 2001 et 2002, in : Baubron, J.- C., Bourgeois, B., Feuga, B., Fourniguet, G., Le Nindre, Y.- M., Nguyen-The, D., Quesnel, F. (with the collaboration of Carnus, E., Catimel, S., Cheval, L. Coutelle, A., Delpont, G., Lopez, B., Marchetto, M., Olivier, L., Perrin, J., Poly, D., Roettger, B., Thomaidis, C.), Étude de l'aléa lié à la dissolution du sel dans le bassin de Dieuze - Château-Salins et incidences sur les aquifères et sur les mouvements de la surface du sol. Rapport final, BRGM/RP-52535-FR.

Connelly, P., Power, D., 2005. Salt Making in Roman Nantwich: Recent Discoveries at Kingsley Fields, Welsh Row, in: Nevell, M., Fielding, A.P. (eds.), Brine in Britannia: Recent Archaeological Work on the Roman Salt Industry in Cheshire, Archaeology Northwest 7(17), 31-40.

Dodds, L.J., 2005. Salt making in Roman Middlewich: Part 2 discovery and rediscovery. Excavations along King Street 2001-2, in: Nevell, M., Fielding, A.P. (eds.), Brine in Britannia: Recent Archaeological Work on the Roman Salt Industry in Cheshire, Archaeology Northwest 7(17), 25-30.

Dufraisse, A. 2002. Salt Springs Exploitation Study in Franche-Comté (France): Contribution of Charcoal. Journal of Archaeological Science 29, 667-675.

Dufraisse, A., Gauthier, E. 2002. Exploitation des sources salées en Franche-Comté: impact sur l'espace forestier du Néolithique à la période médiévale., in: Olivier, W. (ed.), Archeologié du sel: techniques et sociétés dans la pre- et protohistoire europeenne. Actes du Colloque 12.2 du XIVe Corigrès de UISPP, 4 septembre 2001, Liège et de la Table ronde du Comité des salines de France, 18 mai 1998, Paris, $243-257$.

Fawn, A.J., Evans, K.A., McMaster, I., Davies, G.M.R., 1990. The Red Hills of Essex. Colchester Archaeological Group, Colchester.

Fielding, A.P., 2005. Practical Salt Making and the Identification of Early Inland Salt Making Sites in Cheshire, in: Nevell, M., Fielding, A.P. (eds.), Brine in Britannia: Recent Archaeological Work on the Roman Salt Industry in Cheshire, Archaeology Northwest 7(17), 55—64. 
Fielding A. M., Fielding. A.P. (eds.), 2005. Salt works and salinas: The archaeology, conservation and recovery of salt making sites and their processes. Lion Salt Works Trust Monograph Series, Research Report No. 2. Lion Salt Works Trust, Northwich. Flad, R.K., Zhu, J., Wang, C., Chen,P., von Falkenhausen, L,, Sun, Z., Li, S., 2005. Archaeological and chemical evidence for early salt production in China. Proceedings of the National Academy of Sciences 102(34), 12618-12622.

Flad, R.K., Xiaohong, W., von Falkenhausen, L., Shuicheng, L., Zhibin, S., Pochan, C., 2009. Radiocarbon Dates and Technological Change in Salt Production at the Site of Zhongba in the Three Gorges, China. Asian Perspectives 48(1), 148-180. Garner, D., 2005. Salt Making in Roman Middlewich: Part 1. Discoveries Before 2000, in: Nevell, M., Fielding, A.P. (eds.) Brine in Britannia: Recent Archaeological Work on the Roman Salt Industry in Cheshire, Archaeology North West 7(17), 1524.

Van Geel, B., Buurman, J., Waterbolk, H.T., 1996. Archaeological and palaeoecological indications of an abrupt climate change in The Netherlands, and evidence for climatological teleconnections around 2650 BP. Journal of Quaternary Science 11(6), 451-460.

Van Geel, B. Van der Plicht, J., Kilian, M.R., Klaver, E.R., Kouwenberg, J.H.M., Renssen, H., Reynaud-Farrera, I., Waterbolk, H.T., 1998. The sharp rise of $\Delta^{14} \mathrm{C}$ ca. 800 cal BC: Possible causes, related climatic teleconnections and the impact on human environments. Radiocarbon 40(1), 535-550.

Goguel, J. 1959. Service de la carte géologique de al France: Château-Salins, feuille $X X X V$-14. l'Institut Géographique National.

Grossi, M.C., Sivilli, S., Arnoldus-Huyzendveld, A., Facciolo, A., Rinaldi, M.L., Ruggeri, D., Morelli, C. 2015. A complex relationship between human and natural landscape: a multidisciplinary approach to the study of the roman saltworks in "Le Vignole-Interporto" (Maccarese, Fiumicino-Roma), in: Brigand, R. and Weller, O. (eds.), Archaeology of Salt. Approaching an invisible past. Sidestone Press, Leiden, 83-102.

Gurney, D. 1999. Chapter 2: A Romano-British Salt-making Site at Shell Bridge, Holbeach St Johns: Excavations by Ernest Greenfield, 1961, in: Bell, A., Gurney, D., Healey, H. (eds.), Lincolnshire salterns: Excavations at Helpringham Fen, Holbeach St Johns and Bicker Haven. EAA 89, Heritage Trust for Lincolnshire, 21-69. Harding, A., 2013. Salt in Prehistoric Europe. Sidestone Press, Leiden. Healey, H. 1999. Chapter 1: An Iron Age salt-making site at Helpringham Fen, Lincolnshire: Excavations by the Car Dyke Research Group, 1972-7, in: Bell, A., Gurney, D., Healey, H. (eds.) Lincolnshire salterns: Excavations at Helpringham Fen, 
Holbeach St Johns and Bicker Haven. EAA 89, Heritage Trust for Lincolnshire, 119.

Howard, A., Kluiving, S.J., Engel, M., Heyvaert, V.M.A., 2015. Geoarchaeological records in temperate European river valleys: Quantifying the resource, assessing its potential and managing its future. Quaternary International 367, 42-50. Jones, A.P., Tucker, M.E., Hart, J.K. (eds.), 1999. The Description and Analysis of Quaternary Stratigraphic Field Sections. Quaternary Research Association, Technical Guide 7. QRA, London.

Jülich, S., 2005. An Overview of Early Salt Making in Germany, in: Fielding, A.M., Fielding, A.P. (eds.) Salt Works and Salinas: the archaeology, conservation and recovery of salt making sites and their processes. Lion Sat Works Trust Monograph Series, Research Report No. 2, 27-32, Lion Salt Works Trust, Northwich. Jusseret S., Olivier L., Watteaux M., Riddiford N.G., Branch N.P., 2015. Le Briquetage de la Seille (Moselle) : géoarchéologie et archéogéographie d'un complexe d'exploitation intensive du sel à l'âge du Fer, in: Roure R., Olmer F. (eds.), Les Gaulois au fil de l'eau : actes du 37e Colloque international de l'Association Française pour l'Etude de l'Age du Fer, Montpellier, 8-11 mai 2013. Monographies d'Archéologie Méditerranéenne.

Kinory, J., 2012. Salt Production, Distribution and Use in the British Iron Age. BAR British Series 559. Archaeopress, Oxford.

Kleinmann, D., 1975. The salt springs of the Saale Valley, in: de Brisay, K.W., Evans, K.A. (eds.), Salt: The study of an ancient industry. Colchester Archaeology Group, Colchester, pp. 45-46.

Kondo, Y., 1975. The salt industry in ancient Japan, in: de Brisay, K.W., Evans, K.A. (eds.), Salt: The study of an ancient industry. Colchester Archaeology Group, Colchester, pp. $61-65$.

Lane, T., Morris, E.L. (eds.), 2001. A Millennium of Saltmaking: Prehistoric and Romano-British Salt Production in the Fenland, Lincolnshire Archaeology and Heritage Report Series No.4. Heritage Trust of Lincolnshire.

Lane, T., 2005. The Wider Context of the Cheshire Salt Industry: Iron Age and Roman Salt Production Around the Wash, in: Nevell, M., Fielding, A.P. (eds.), Brine in Britannia: Recent Archaeological Work on the Roman Salt Industry in Cheshire, Archaeology Northwest 7(17), 47-54.

Langouët, L., Gouletquer, P., Bizien-Jaglin, C., 1994. De la tangue au sel : briquetage et expérimentations, in : Daire, M.Y. (ed.), Le sel gaulois. Bouilleurs de sel et ateliers de briquetage armoricains à l'âge du Fer. Saint-Malo Centre régional d'Archéologie d'Alet, 111-122. 
Marchal, C.I., Maréchal, B. and Laugier, R. 1972. Carte géologique détaillée de la France: Parroy, feuille XXXV-1. L'Institut Géographique National, France.

Martin, J.J., 1975. Collected notes on the salt industry of the Cumbrian Solway coast, in: de Brisay, K.W., Evans, K.A. (eds.), Salt: The study of an ancient industry. Colchester Archaeology Group, Colchester, pp. 71-76.

Meier, D., 2004. Man and environment in the marsh area of Schleswig-Holstein from Roman until late Medieval times. Quaternary International 112(1), 55—69.

Multhauf, R.P., 1978. Neptune's Gift: A history of common salt. The John Hepkins University Press, Baltimore.

Nevell, M., Fielding, A.P. (eds.), 2005. Brine in Britannia: Recent Archaeological Work on the Roman Salt Industry in Cheshire, Archaeology North West, 7(17).

Nevell, M., 2005. Salt Making in Cheshire: The Iron Age Background, in: Nevell, M., Fielding, A.P. (eds.), Brine in Britannia: Recent Archaeological Work on the Roman Salt Industry in Cheshire, Archaeology North West, 7(17), 9-14.

Notebaert, B., Verstraeten, G., 2010. Sensitivity of West and Central European river systems to environmental changes during the Holocene: A review. Earth Science Reviews 103, 163-182.

Olivier, L., 2000. Le « Briquetage de la Seille » (Moselle) : nouvelles recherches sur une exploitation proto-industrielle du sel à l'âge du Fer. Antiquités nationales 32, $143-171$.

Olivier, L., 2010. Contribution à l'étude de l'évolution techno-typologique des modes de production du sel dans la vallée de la Seille (Moselle) à l'âge du Fer. Antiquités nationales 40, 119-137.

Olivier, L., 2014. Le site d'atelier de briquetage de Marsal « La Digue » (Moselle) : état des connaissances avant l'opération, in: Olivier, L. (ed.), Marsal « la Digue » (Moselle) Fouille programmée : Campagne 2014. Unpublished, 29-64.

Olivier, L., Kovacik, J., 2006. The 'Briquetage de la Seille' (Lorraine, France): protoindustrial salt production in the European Iron Age. Antiquity 80, 558-566.

Olivier L., Kovacik, J., 2007. The Contribution of Geophysical Reconnaissance towards Understanding the Proto-industrial Salt Making Workshops of the Briquetage de la Seille (Moselle, France), in: Posselt, M., Zickgraf, B., Dobiat, C. (eds.), Geophysic und Ausgrabung. Einsatz und Auswertung zerstörungsfrei Prospektion in Archäologie. Radhen, éditions Marie Leidorf (Internationale Archäologie:

Naturwissenschaft und Technologie) 6, 327-251.

Olivier, L. Branch, N.P., Bravard, J.-P., Coutelle, A., Charlier, P., Evans, J., Jay, M., Jouanin, G., Montgomery, J., Kremer, C., Lagadec, J.-P., Li, S., Remor, G., Riddiford, N.G., Tegel, W., Williams, K., Wirtz, B., 2010. Nouvelles recherches sur le 
site de sauniers du premier âge du Fer de Marsal « la Digue » (Moselle). Antiquités nationales, 41, 127-160.

Pétrequin, P., Weller, O., Gauthier, E., Dufraisse, A., Piningre, J-F. 2001. Salt springs expoitation without pottery during Prehistory. From New Guinea to the French Jura, in: Beyries, S., Pétrequin, P. (eds.), Ethno-archaeology and its transfers. Papers from a session held at the European Association of Archaeologists Fifth Annual Meeting in Bournemouth 1999. BAR International Series 983, 37-65.

Reimer, P.J., Bard, E., Bayliss, A., Beck, J.W., Blackwell, P.G., Bronk Ramsey, C., Buck, C.E., Cheng, H., Edwards, R.L., Freidrich, M., Grootes, P.M., Guilderson, T.P., Haflidason, H., Hajdas, I., Hatté, C., Heaton, T.J., Hoffmann, D.L., Hogg, A.G., Hughen, K.A., Kaiser, K.F., Kromer, B., Manning, S., Niu, M., Reimer, R.W., Richards, D.A., Scotts, E.M., Southon, J. R., Staff, R.A., Turney, C.S.M., Van der Plicht, J., 2013. Intcal13 and Marine13 Radiocarbon Age Calibration Curves 050,000 years cal BP. Radiocarbon 55(4), 1869-1887.

Riddiford, N.G., Branch, N.P., Green, C.P., Armitage, S.J., Olivier, L., 2012. Holocene palaeoenvironmental change and the impact of prehistoric salt production in the Seille Valley, eastern France. The Holocene 22(8), 831-845.

Schepers, M. Cappers, R.T.J., Bekker, R.M., 2013. A review of prehistoric and early historic mainland salt marsh vegetation in the northern-Netherlands based on the analysis of plant macrofossils. Journal of Coastal Conservation 17, 755-773. Shotter, D., 2005. Salt Proprietors in Cheshire. Realities and Possibilities, in: Nevell, M., Fielding, A.P. (eds.) Brine in Britannia: Recent Archaeological Work on the Roman Salt Industry in Cheshire, Archaeology North West, 7(17), 41-47.

Tessier, M., 1975. The protohistoric salt making sites of the Pays de Retz, France, in: de Brisay, K.W., Evans, K.A. (eds.), Salt: The study of an ancient industry. Colchester Archaeology Group, Colchester, pp. 52-56.

Thoen, H., 1975. Iron Age and Roman salt-making sites on the Belgium coast, in: de Brisay, K.W., Evans, K.A. (eds.), Salt: The study of an ancient industry. Colchester Archaeology Group, Colchester, pp. 56-60.

Tora, Y., Vogel, H.U., 1993. Salt Production Techniques in Ancient China: The Aobo Tu. Leiden, New York.

Went, C., 2011. Introductions to Heritage Assets: Pre-industrial Salterns. English Heritage. http://www.english-heritage.org.uk/publications/iha-preindustrialsalterns/preindustrialsalterns.pdf - Accessed 01/08/14 Woodiwiss, S., 1992. Introduction, in: Woodiwiss, S. (ed.), Iron Age and Roman Salt Production and the Medieval town of Droitwich. CBA Research Report No.81, Hereford and Worcester County Council, 1-7. 
ZhiBin, S. 2008. Research on the relationship between site function and environment at the site of Zhongba, Chongqing City, China. Chinese Science Bulletin 53, 58-73. Zolitschka, B., Behre, K-E., Schneider, J., 2003. Human and climatic impact on the environment as derived from colluvial, fluvial and lacustrine archives - examples from the Bronze Age to the Migration period, Germany. Quaternary Science Reviews 22, 81-100. 


\section{Supplementary material}

\section{Sediment core descriptions for "La Digue" (Upper Seille Valley, Lorraine, France)}

Borehole codes and grid references are given for each core sample. Elevation is presented in meters above sea level ( $m$ a.s.I.). All cores were described in the field, with the exception of BH69-L, BH81-L, BH88-L and BH99-L, which were described in the laboratory and sampled for radiocarbon dating. Radiocarbon dated horizons and results are highlighted in bold in the relevant tables.

Table 1: BH52 (32N 324271, 5406411)

\begin{tabular}{|l|l|}
\hline $\begin{array}{l}\text { Elevation } \\
\text { (m a.s.I.) }\end{array}$ & Description \\
\hline $202.04-$ & Dark brown; pedogenically altered alluvium; briquetage; frequent \\
192.04 & rooting \\
\hline $192.04-$ & Dark brown silty clay; frequent rooting \\
201.85 & \\
\hline $201.85-$ & Grey brown silty clay; briquetage \\
201.76 & \\
\hline $201.76-$ & Dark brown silty clay; large fragments of briquetage \\
201.63 & \\
\hline $201.63-$ & Dark grey silty clay; frequent charcoal, briquetage \\
201.26 & \\
\hline $201.26-$ & Layer of briquetage \\
201.22 & \\
\hline $201.22-$ & Light yellowish brown clay; charcoal present \\
201.19 & \\
\hline $201.19-$ & Dark grey silty clay; charcoal and briquetage inclusions \\
201.12 & \\
\hline $201.12-$ & Briquetage layer \\
200.88 & \\
\hline $200.88-$ & Light yellowish brown silty clay with small gravel; occasional charcoal \\
200.81 & \\
\hline $200.81-$ & Dark brown silty clay; charcoal, briquetage and bone \\
200.68 & \\
\hline $200.68-$ & Dark grey brown silty clayey gravel; small briquetage and charcoal \\
200.30 & \\
\hline $200.30-$ & Dark grey silty clay; small charcoal \\
200.27 & Dark grey brown silty clayey gravel; small briquetage and charcoal \\
\hline $200.27-$ & \\
200.18 & Dark grey silty clay; small charcoal \\
\hline $200.18-$ & \\
200.17 & Dark grey brown silty clayey gravel; small briquetage and charcoal \\
\hline $200.17-$ & \\
200.14 & Dark grey silty clay; small charcoal \\
\hline $200.14-$ & \\
200.13 & Dark grey brown silty clayey gravel; small briquetage and charcoal \\
\hline $200.13-$ & \\
\hline
\end{tabular}




\begin{tabular}{|c|c|}
\hline 199.59 & \\
\hline $\begin{array}{l}199.59- \\
199.46\end{array}$ & $\begin{array}{l}\text { Dark brown/black silty clay (pedogenically altered alluvium) } \\
1260-1000 \text { cal BCE (Beta-266133): } 199.58-199.56 \text { m a.s.l. } \\
1510-1300 \text { cal BCE (Beta-266134): } 199.48-199.46 \text { m a.s.l. }\end{array}$ \\
\hline $\begin{array}{l}199.46- \\
198.82\end{array}$ & $\begin{array}{l}\text { Dark blue grey silty clay with occasional gravel; infrequent organic } \\
\text { matter }\end{array}$ \\
\hline $\begin{array}{l}198.82- \\
198.44\end{array}$ & Mottled reddish brown and yellowish brown silty clay \\
\hline $\begin{array}{l}198.44- \\
198.22\end{array}$ & Mottled reddish brown and yellowish brown clayey sandy silt \\
\hline $\begin{array}{l}198.22- \\
198.18\end{array}$ & Blue grey silty clay \\
\hline $\begin{array}{l}198.18- \\
197.74\end{array}$ & Mottled reddish brown and yellowish brown clayey sandy silt \\
\hline $\begin{array}{l}197.74- \\
197.19\end{array}$ & Yellowish brown silty sandy gravel \\
\hline $\begin{array}{l}197.19- \\
196.67\end{array}$ & $\begin{array}{l}\text { Mottled very dark brown/black-dark grey silty clay with fine sand and } \\
\text { gravel; possibly organic-rich soil/sediment }\end{array}$ \\
\hline $\begin{array}{l}196.67- \\
196.48\end{array}$ & Black peat; highly decomposed and compacted \\
\hline $\begin{array}{l}196.48- \\
196.42\end{array}$ & Yellowish brown silty sandy clay; pellets of grey clay and Manganese \\
\hline $\begin{array}{l}196.42- \\
196.39\end{array}$ & Dark grey and orange clay with fine gravel \\
\hline $\begin{array}{l}196.39- \\
196.25\end{array}$ & Olive green sandy silt with fine gravel \\
\hline $\begin{array}{l}196.25- \\
196.04\end{array}$ & Light grey sandy silty gravel \\
\hline
\end{tabular}

Table 2: BH68 (32N 324249, 5406429)

\begin{tabular}{|l|l|}
\hline $\begin{array}{l}\text { Elevation } \\
\text { (m a.s.I.) }\end{array}$ & Description \\
\hline $201.84-$ & $\begin{array}{l}\text { Dark greyish brown; pedogenically altered alluvium; clayey silt; common } \\
201.78\end{array}$ \\
modern roots; sharp boundary to
\end{tabular}




\begin{tabular}{|l|l|}
\hline $\begin{array}{l}199.29- \\
198.52\end{array}$ & $\begin{array}{l}\text { Mottled grey to dark grey to very dark brown organic sandy silt } \\
\text { containing wood macrofossils and sedge grass remains; black charcoal } \\
\text { and ash layer between 199.02-198.98; gradual to }\end{array}$ \\
\hline $\begin{array}{l}198.52- \\
198.38\end{array}$ & Dark grey silty clay containing blocky briquetage; sharp to \\
\hline $\begin{array}{l}198.38- \\
197.84\end{array}$ & $\begin{array}{l}\text { Mottled light to dark grey organic clayey silt containing very fine plant } \\
\text { matter throughout; olive grey gravelly sand layer at 198.32-198.20; } \\
\text { small wood fragments at 198.33 and 198.15; gradual to }\end{array}$ \\
\hline $\begin{array}{l}197.84- \\
197.58\end{array}$ & $\begin{array}{l}\text { Light grey silty clay containing dark brown peat and fine plant matter; } \\
\text { possibly alluvium containing redeposited peat; sharp to }\end{array}$ \\
\hline $\begin{array}{l}197.58- \\
197.51\end{array}$ & $\begin{array}{l}\text { Dark brown peat becoming increasingly silty towards base (197.54- } \\
197.51) ; \text { contains very fine plant matter; sharp to }\end{array}$ \\
\hline $\begin{array}{l}197.51- \\
197.38\end{array}$ & $\begin{array}{l}\text { Olive grey clay containing fine plant matter and shell fragments; gradual } \\
\text { to }\end{array}$ \\
\hline $\begin{array}{l}\text { 197.38- } \\
197.30\end{array}$ & $\begin{array}{l}\text { Mottled olive grey to light grey fine sandy gravel in silty matrix; contains } \\
\text { shell fragments and fine plant matter; sharp to }\end{array}$ \\
\hline $\begin{array}{l}197.30- \\
196.84\end{array}$ & Light grey silty sandy gravel \\
\hline
\end{tabular}

Table 3: BH69-L (32N 324261, 5406426)

\begin{tabular}{|c|c|c|}
\hline $\begin{array}{l}\text { Elevation } \\
\text { (m a.s.I.) }\end{array}$ & Colour & Description \\
\hline $\begin{array}{l}201.83- \\
201.64\end{array}$ & $\begin{array}{l}7.5 Y R 3 / 1 \\
\text { Very dark } \\
\text { grey }\end{array}$ & $\begin{array}{l}\text { Pedogenically altered alluvium containing modern roots } \\
\text { and sand and fine gravel-sized briquetage (maximum } 0.2 \\
\mathrm{~cm} \text { ); sharp to }\end{array}$ \\
\hline $\begin{array}{l}201.64- \\
201.56\end{array}$ & $\begin{array}{l}5 \text { YR } 8 / 1 \\
\text { White }\end{array}$ & $\begin{array}{l}\text { Horizontally bedded blocky white lithology (limestone } \\
\text { masonry). Blocky briquetage at } 201.61-201.59 \text { and } \\
201.59-201.58 \text { (5YR 6/8 Reddish yellow); gradual to }\end{array}$ \\
\hline $\begin{array}{l}201.56- \\
201.54\end{array}$ & $\begin{array}{l}5 Y R 6 / 8 \\
\text { Reddish } \\
\text { yellow }\end{array}$ & $\begin{array}{l}\text { Blocky briquetage (continuation of above, but no } \\
\text { limestone); sharp to }\end{array}$ \\
\hline $\begin{array}{l}201.54- \\
201.49\end{array}$ & $\begin{array}{l}\text { 7.5YR 4/3 } \\
\text { Brown }\end{array}$ & $\begin{array}{l}\text { Sandy silty clay containing sand and gravel-sized } \\
\text { briquetage and occasional small limestone clasts (up to } 0.5 \\
\mathrm{~cm} \text { ); modern roots; gradual to }\end{array}$ \\
\hline $\begin{array}{l}201.48- \\
201.34\end{array}$ & $\begin{array}{l}5 Y R \text { Y/2 } \\
\text { Dark } \\
\text { reddish } \\
\text { grey }\end{array}$ & $\begin{array}{l}\text { Silty clay containing sparse modern roots and fine gravel- } \\
\text { sized briquetage and limestone }(\leq 1 \mathrm{~mm}) \text {; blocky briquetage } \\
(0.5-1.5 \mathrm{~cm}) \text { in a silty clay matrix at } 201.38-201.34 \text {; } \\
\text { gradual to }\end{array}$ \\
\hline $\begin{array}{l}201.34- \\
201.11\end{array}$ & $\begin{array}{l}7.5 Y R \text { Y/1 } \\
\text { Dark grey }\end{array}$ & $\begin{array}{l}\text { Silty clay containing blocky briquetage at } 201.32-201.26 \text {; } \\
\text { charcoal fragments at } 201.33-201.32 \text { and } 201.25 ; \text { blocky } \\
\text { limestone at } 201.34-201.33,201.32,201.31 \text { and } 201.19 ; \\
\text { small limestone fragments and sparse gravel-sized } \\
\text { briquetage }(<0.1 \mathrm{~cm}) \text { throughout; gradual to }\end{array}$ \\
\hline $\begin{array}{l}201.11- \\
201.00\end{array}$ & $\begin{array}{l}2.5 Y 4 / 3 \\
\text { Olive } \\
\text { brown }\end{array}$ & $\begin{array}{l}\text { Mottled clay containing crumbling briquetage fragments } \\
(\sim 0.3 \mathrm{~cm}) \text { and charcoal throughout; gradual to }\end{array}$ \\
\hline $\begin{array}{l}201.00- \\
200.80\end{array}$ & $\begin{array}{l}2.5 Y 2.5 / 1 \\
\text { Black }\end{array}$ & $\begin{array}{l}\text { Faintly mottled clay containing crumbling briquetage }(0.1-1 \\
\mathrm{cm}) \text { and small limestone fragments }(\sim 0.1 \mathrm{~cm}) \text {; occasional } \\
\text { charcoal throughout; horizontally bedded block of } \\
\text { briquetage }(2 \mathrm{~cm} \times 4 \mathrm{~cm}) \text { at } 200.83-200.81 \text {; gradual to }\end{array}$ \\
\hline $\begin{array}{l}200.80- \\
200.77\end{array}$ & $\begin{array}{l}2.5 Y 2.5 / 1 \\
\text { Black }\end{array}$ & $\begin{array}{l}\text { Silt containing horizontal plant beds (Phragmites stems) } \\
\text { between 200.80-200.79; sharp to }\end{array}$ \\
\hline
\end{tabular}




\begin{tabular}{|c|c|c|}
\hline $\begin{array}{l}200.77- \\
200.75\end{array}$ & $\begin{array}{l}2.5 Y 5 / 1 \\
\text { Grey }\end{array}$ & Mottled silt; sharp to \\
\hline $\begin{array}{l}200.75- \\
200.23\end{array}$ & $\begin{array}{l}\text { 7.5YR 4/2 } \\
\text { Brown }\end{array}$ & $\begin{array}{l}\text { Clayey silt rich in briquetage; occasional charcoal } \\
\text { fragments present throughout (e.g., at } 200.49-200.48) \text {; } \\
\text { sand and gravel-sized briquetage }(0.1-0.5 \mathrm{~cm}) \text { common; } \\
\text { blocky briquetage }(1 \mathrm{~cm} \times 2 \mathrm{~cm} \text { to } 3 \mathrm{~cm} \times 2 \mathrm{~cm} \text { ) at } 200.57- \\
200.55,200.47-200.42 \text { and } 200.35-200.24 ; \text { gradual to } \\
\mathbf{1 0 5 0 - 1 2 6 0 ~ C E ~ ( B e t a - 3 6 5 3 5 9 ) : ~} 200.74-200.72 \text { m a.s.l. }\end{array}$ \\
\hline $\begin{array}{l}200.23- \\
199.95\end{array}$ & $\begin{array}{l}\text { 7.5YR } 3 / 1 \\
\text { Very dark } \\
\text { grey }\end{array}$ & $\begin{array}{l}\text { Silt rich in blocky and gravel-sized briquetage; large } \\
\text { charcoal fragments at } 200.12-200.10 \text { and } 200.08-200.06 \text {; } \\
\text { charcoal-rich layer at } 199.98-199.95 \text {; sharp to }\end{array}$ \\
\hline $\begin{array}{l}199.95- \\
199.83\end{array}$ & $\begin{array}{l}2.5 Y 3 / 2 \\
\text { Very dark } \\
\text { greyish } \\
\text { brown }\end{array}$ & $\begin{array}{l}\text { Sandy silt with horizontal charcoal layers at } 199.93,199.92, \\
199.91-199.88 \text { and } 199.86-199.83 ; \text { sand layer at } 199.88- \\
199.87 \text {; blocky briquetage at } 199.95-199.93,199.90, \\
199.85 \text { and } 199.83\end{array}$ \\
\hline $\begin{array}{l}199.83- \\
199.68\end{array}$ & $\begin{array}{l}2.5 Y 2.5 / 1 \\
\text { Black }\end{array}$ & $\begin{array}{l}\text { Fine sandy silt; small clay lens (or disintegrated briquetage) } \\
\text { at } 199.81 \text { (2.5Y } 6 / 4 \text { Light yellowish brown); small charcoal } \\
\text { fragments ( } \sim \mathrm{mm}) \text { and sand and gravel-sized briquetage } \\
\text { throughout; large horizontal charcoal fragment ( } 2 \mathrm{~cm} \times 0.5 \\
\mathrm{~cm}) \text { at } 199.70 \text {; horizontally-bedded blocky briquetage at } \\
199.70-199.68 \text {; sharp to }\end{array}$ \\
\hline $\begin{array}{l}199.68- \\
199.675\end{array}$ & $\begin{array}{l}2.5 Y 6 / 4 \\
\text { Light } \\
\text { yellowish } \\
\text { brown }\end{array}$ & Clay; sharp to \\
\hline $\begin{array}{l}199.675- \\
199.67\end{array}$ & $\begin{array}{l}7.5 Y R \\
2.5 / 1 \\
\text { Black }\end{array}$ & Peaty silt; sharp to \\
\hline $\begin{array}{l}199.67- \\
199.66\end{array}$ & $\begin{array}{l}2.5 Y 6 / 4 \\
\text { Light } \\
\text { yellowish } \\
\text { brown }\end{array}$ & $\begin{array}{l}\text { Clay-rich silt; silty clay lens (disintegrated briquetage?) } 1 \\
\mathrm{~cm} \times 0.5 \mathrm{~cm} \text { at } 199.67-199.66 \text { (7.5YR } 6 / 8 \text { Reddish yellow); } \\
\text { sharp to }\end{array}$ \\
\hline $\begin{array}{l}199.66- \\
199.55\end{array}$ & $\begin{array}{l}7.5 Y R \\
2.5 / 1 \\
\text { Black }\end{array}$ & $\begin{array}{l}\text { Sandy silt becoming silty sand downwards; } 1.5 \mathrm{~cm} \times 0.5 \mathrm{~cm} \\
\text { black peat fragment in silty sand at } 199.62-199.60 \text {; sparse } \\
\text { coarse sand-fine gravel at } 199.57-199.55 \text {; woody fragment } \\
(1.5 \mathrm{~cm} \times 1 \mathrm{~cm}) \text { at } 199.56-199.55 \text { (archaeology); sharp to } \\
\mathbf{7 9 0 - 4 9 0} \text { cal BCE (Beta-285295): } \mathbf{1 9 9 . 6 3 - 1 9 9 . 6 1 ~ m ~ a . s . I . ~}\end{array}$ \\
\hline $\begin{array}{l}199.55- \\
199.54\end{array}$ & $\begin{array}{l}2.5 Y 5 / 1 \\
\text { Grey }\end{array}$ & Clay; sharp to \\
\hline $\begin{array}{l}199.54- \\
199.50\end{array}$ & $\begin{array}{l}2.5 Y 2.5 / 1 \\
\text { Black }\end{array}$ & $\begin{array}{l}\text { Silty clay becoming increasingly sandy downwards; } \\
\text { horizontal wood fragment }(3.5 \mathrm{~cm} \times 0.5 \mathrm{~cm}) \text { at } 199.53- \\
199.525 \text { (archaeology); horizontal clast }(2 \mathrm{~cm} \times 0.5 \mathrm{~cm}) \text { at } \\
199.525-199.52 \text {; sandy silt between } 199.52-199.50 \text {; } \\
\text { gradual to }\end{array}$ \\
\hline $\begin{array}{l}199.50- \\
199.48\end{array}$ & $\begin{array}{l}2.5 Y 2 / 1 \\
\text { Black }\end{array}$ & $\begin{array}{l}\text { Silty clay rich in horizontally bedded woody remains } 0.5 \mathrm{~cm} \\
\mathrm{x} 1 \mathrm{~cm} \text { (archaeology); sharp to }\end{array}$ \\
\hline $\begin{array}{l}199.48- \\
199.47\end{array}$ & $\begin{array}{l}2.5 Y 4 / 2 \\
\text { Dark } \\
\text { greyish } \\
\text { brown }\end{array}$ & $\begin{array}{l}\text { Sandy gravely silt rich in coarse sand and fine gravel; sharp } \\
\text { to }\end{array}$ \\
\hline $\begin{array}{l}199.47- \\
199.22\end{array}$ & $\begin{array}{l}2.5 Y 2 / 1 \\
\text { Black }\end{array}$ & $\begin{array}{l}\text { Fine sandy silt very rich in horizontally bedded wood } \\
\text { (archaeology); fragments up to } 1.5 \mathrm{~cm} \times 3 \mathrm{~cm} \text {; peaty } \\
\text { between 199.24-199.22; wood small and sparse between } \\
\text { 199.24-199.22; sharp to }\end{array}$ \\
\hline
\end{tabular}




\begin{tabular}{|c|c|c|}
\hline & & 740-380 cal BCE (Beta-285294): 199.46-199.44 m a.s.l. \\
\hline $\begin{array}{l}199.22- \\
199.18\end{array}$ & $\begin{array}{l}2.5 Y \text { Y } 4 / 1 \\
\text { Dark grey }\end{array}$ & $\begin{array}{l}\text { Silt containing sparse small wood fragments and coarse } \\
\text { gravel up to } 0.5 \mathrm{~cm} \text {; large horizontal wood fragment }(2 \mathrm{~cm} \mathrm{x} \\
0.5 \mathrm{~cm} \text { ) at } 199.185-199.18 \text { (archaeology); gradual to }\end{array}$ \\
\hline $\begin{array}{l}199.18- \\
199.15\end{array}$ & $\begin{array}{l}2.5 Y \text { Y } 4 / 1 \\
\text { Dark grey }\end{array}$ & $\begin{array}{l}\text { Disaggregated/crumbly fine sandy silt containing scattered } \\
\text { fine plant matter (Phragmites stems); gradual to } \\
750-400 \text { cal BCE (Beta-285293): 199.18-199.16 m a.s.l. }\end{array}$ \\
\hline $\begin{array}{l}199.15- \\
199.09\end{array}$ & $\begin{array}{l}2.5 Y \text { Y } 4 / 1 \\
\text { Dark grey }\end{array}$ & $\begin{array}{l}\text { Sandy silty clay containing blocky briquetage (up to } 1 \mathrm{~cm} \text { ) } \\
\text { and charcoal throughout; gradual to }\end{array}$ \\
\hline $\begin{array}{l}199.09- \\
199.00\end{array}$ & $\begin{array}{l}2.5 Y 5 / 3 \\
\text { Light olive } \\
\text { brown }\end{array}$ & $\begin{array}{l}\text { Silty clay containing scattered charcoal and fine gravel- } \\
\text { sized briquetage }(\sim 0.3 \mathrm{~cm}) \text {; briquetage is increasingly } \\
\text { sparse and smaller downwards; sharp to }\end{array}$ \\
\hline $\begin{array}{l}199.00- \\
198.74\end{array}$ & $\begin{array}{l}\text { 7.5YR } 4 / 1 \\
\text { Dark grey }\end{array}$ & $\begin{array}{l}\text { Clay containing sparse very fine gravel/coarse sand-sized } \\
\text { briquetage }(<0.2 \mathrm{~cm}) \text { and charcoal throughout; gravel-sized } \\
\text { briquetage }(1 \mathrm{~cm} \times 1.5 \mathrm{~cm}) \text { at } 198.945-198.935 \text {; clay } \\
\text { containing sparse small charcoal fragments }(0.1-0.2 \mathrm{~cm}) \text {; } \\
\text { gradual to }\end{array}$ \\
\hline $\begin{array}{l}198.74- \\
198.37\end{array}$ & $\begin{array}{l}7.5 Y R \text { Y/1 } \\
\text { Dark grey }\end{array}$ & 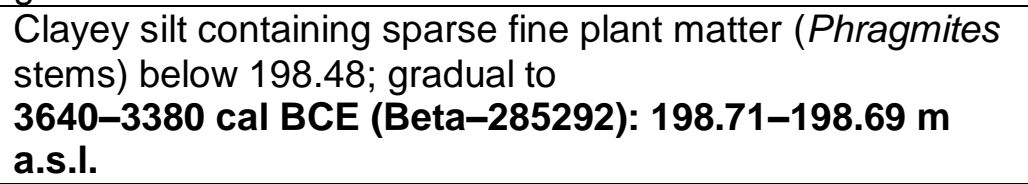 \\
\hline $\begin{array}{l}198.37- \\
197.99\end{array}$ & $\begin{array}{l}7.5 Y R \text { Y } 4 / 1 \\
\text { Dark grey }\end{array}$ & $\begin{array}{l}\text { Clayey silt containing fine plant matter throughout } \\
\text { (Phragmites stems); gradual to } \\
4900-4710 \text { cal BCE (Beta-285291): 198.28-198.26 m } \\
\text { a.s.I. } \\
5720-5560 \text { cal BCE (Beta-285290): 198.05-198.03 m } \\
\text { a.s.l. }\end{array}$ \\
\hline $\begin{array}{l}197.99- \\
197.89\end{array}$ & $\begin{array}{l}7.5 Y R 3 / 1 \\
\text { Very dark } \\
\text { grey }\end{array}$ & $\begin{array}{l}\text { Clayey silt containing occasional plant remains (Phragmites } \\
\text { stems); intact horizontally bedded Mollusc shell at } 197.905 \\
(0.3 \mathrm{~cm} \times 0.2 \mathrm{~cm}) \text {; gradual to }\end{array}$ \\
\hline $\begin{array}{l}197.89- \\
197.83\end{array}$ & $\begin{array}{l}7.5 \mathrm{YR} \\
2.5 / 1 \\
\text { Black }\end{array}$ & $\begin{array}{l}\text { Peaty silty clay containing common plant remains } \\
\text { (Phragmites stems) }\end{array}$ \\
\hline $\begin{array}{l}197.83- \\
197.75\end{array}$ & $\begin{array}{l}2.5 Y 3 / 1 \\
\text { Very dark } \\
\text { grey }\end{array}$ & $\begin{array}{l}\text { Peaty silty clay containing occasional fine woody remains; } \\
\text { gradual to } \\
7810-7580 \text { cal BCE (Beta-285288): 197.77-197.74 m } \\
\text { a.s.I. }\end{array}$ \\
\hline $\begin{array}{l}197.75- \\
197.53\end{array}$ & $\begin{array}{l}2.5 Y 4 / 2 \\
\text { Dark } \\
\text { greyish } \\
\text { brown }\end{array}$ & $\begin{array}{l}\text { Fine sandy silt becoming increasingly sandy downwards; } \\
\text { Mollusca common below } 197.62 \text {; horizontally bedded whole } \\
\text { shell }(1.5 \mathrm{~cm}) \text { at } 197.62 \text {; horizontal charcoal fragment }(1.5 \\
\mathrm{cm} \times 0.3 \mathrm{~cm}) \text { at } 197.54 \text {; fine roots present between } 197.60- \\
197.53 ; \text { gradual to } \\
\mathbf{9 2 8 0 - 8 8 5 0 ~ c a l ~ B C E ~ ( B e t a - 2 8 5 2 8 7 ) : ~ 1 9 7 . 6 4 - 1 9 7 . 6 2 ~ m ~} \\
\text { a.s.l. }\end{array}$ \\
\hline $\begin{array}{l}197.53- \\
197.43\end{array}$ & $\begin{array}{l}2.5 Y 3 / 1 \\
\text { Very dark } \\
\text { grey }\end{array}$ & $\begin{array}{l}\text { Peaty sandy silt rich in horizontally bedded whole and } \\
\text { broken Mollusca; shell bed at 197.47-197.46; horizontally } \\
\text { bedded plant remains below 197.50; relatively sharp to } \\
\text { 9250-8840 cal BCE (Beta-285286): 197.46-197.43 m } \\
\text { a.s.I. }\end{array}$ \\
\hline $\begin{array}{l}197.43- \\
197.17\end{array}$ & $\begin{array}{l}2.5 Y 4 / 2 \\
\text { Dark } \\
\text { greyish } \\
\text { brown }\end{array}$ & $\begin{array}{l}\text { Silty clay containing horizontally bedded plant remains } \\
\text { throughout (less frequent below 197.26); increasingly silty } \\
\text { downwards, becoming clay-rich silt below 197.26; common } \\
\text { whole and broken Mollusca between } 197.43-197.37 \text { (less } \\
\text { frequent below 197.37); whole Mollusca at } 197.32 \text { and }\end{array}$ \\
\hline
\end{tabular}




\begin{tabular}{|l|l|l|}
\hline & & $\begin{array}{l}\text { 197.30; sparse Mollusca between 197.26-197.22, more } \\
\text { frequent again from 197.22-197.17; sharp to } \\
\text { 10,100-9550 cal BCE (Beta-285285): 197.19-197.16 m } \\
\text { a.s.I. }\end{array}$ \\
\hline $\begin{array}{l}197.17- \\
197.09\end{array}$ & $\begin{array}{l}\text { 2.5Y 4/1 } \\
\text { Dark grey }\end{array}$ & $\begin{array}{l}\text { Silty fine sand rich in Mollusca; fine gravel below 197.14; } \\
\text { wood at 197.15 and possibly a root or branch (1 cm x 0.5 } \\
\text { cm) at 197.13-197.12 (cut through during coring); gradual } \\
\text { to }\end{array}$ \\
\hline $\begin{array}{l}\text { 197.09- } \\
196.87\end{array}$ & $\begin{array}{l}\text { 2.5Y 5/1 } \\
\text { Grey }\end{array}$ & $\begin{array}{l}\text { Sandy gravel increasing in grain size downwards; angular } \\
\text { and rounded horizontally bedded gravel; woody fragment at } \\
196.96-196.94 ; \text { sharp to }\end{array}$ \\
\hline $\begin{array}{l}196.87- \\
196.83\end{array}$ & $\begin{array}{l}\text { 2.5Y 2.5/1 } \\
\text { Black }\end{array}$ & Silty sandy gravel \\
\hline
\end{tabular}

Table 4: BH77 (32N 324250, 5406417)

\begin{tabular}{|c|c|}
\hline $\begin{array}{l}\text { Elevation } \\
\text { (m a.s.I.) }\end{array}$ & Description \\
\hline $\begin{array}{l}202.01- \\
201.77\end{array}$ & $\begin{array}{l}\text { Dark brown silt containing modern roots; pedogenically altered } \\
\text { alluvium; blocky and gravel-sized briquetage between 201.93-201.77; } \\
\text { gradual to }\end{array}$ \\
\hline $\begin{array}{l}201.77- \\
201.69\end{array}$ & $\begin{array}{l}\text { Dark brown stiff clay containing blocky and gravel-sized briquetage } \\
\text { and modern roots; sharp to }\end{array}$ \\
\hline $\begin{array}{l}201.69- \\
201.62\end{array}$ & $\begin{array}{l}\text { Reddish-orange blocky briquetage and gravel-sized briquetage; sharp } \\
\text { to }\end{array}$ \\
\hline $\begin{array}{l}201.62- \\
201.15\end{array}$ & $\begin{array}{l}\text { Dark brown stiff clay containing blocky and gravel-sized briquetage; } \\
\text { limestone clast at 201.50-201.48; small limestone clasts and } \\
\text { occasional charcoal throughout; charcoal layer at 201.15; gradual to }\end{array}$ \\
\hline $\begin{array}{l}201.15- \\
201.01\end{array}$ & $\begin{array}{l}\text { Dark greyish brown silty gravely clay containing limestone clasts and } \\
\text { occasional charcoal; rich in plant macrofossils throughout }\end{array}$ \\
\hline $\begin{array}{l}201.01- \\
200.58\end{array}$ & $\begin{array}{l}\text { Dark greyish brown silt rich in plant macrofossils and fine plant matter; } \\
\text { charcoal fragment at } 200.82-200.81 \text {; gradual to }\end{array}$ \\
\hline $\begin{array}{l}200.58- \\
200.20\end{array}$ & $\begin{array}{l}\text { Dark grey gravely clay containing sand-sized briquetage and charcoal; } \\
\text { common plant macrofossils throughout; shell fragments between } \\
200.45-200.36 \text {; Mollusca between } 200.30-200.28 ; \text { gradual to }\end{array}$ \\
\hline $\begin{array}{l}200.20- \\
200.15\end{array}$ & $\begin{array}{l}\text { Dark grey sandy silty gravely clay containing sand and gravel-sized } \\
\text { briquetage and common plant macrofossils throughout; gradual to }\end{array}$ \\
\hline $\begin{array}{l}200.15- \\
200.03\end{array}$ & $\begin{array}{l}\text { Dark grey silty gravely clay containing sand and gravel-sized } \\
\text { briquetage; gradual to }\end{array}$ \\
\hline $\begin{array}{l}200.03- \\
200.01\end{array}$ & Blocky briquetage and charcoal in a dark grey-black silty matrix \\
\hline $\begin{array}{l}200.01- \\
199.01\end{array}$ & $\begin{array}{l}\text { Wet slurry of blocky and gravel-sized briquetage and charcoal in dark } \\
\text { greyish brown sandy gravely silt; drier between 199.17-199.01 }\end{array}$ \\
\hline $\begin{array}{l}199.01- \\
198.01\end{array}$ & $\begin{array}{l}\text { Continuation of above; woody remains throughout, most common } \\
\text { between 198.34-198.36; blocky briquetage fragment between 198.36- } \\
\text { 198.28 }\end{array}$ \\
\hline $\begin{array}{l}198.01- \\
197.86\end{array}$ & $\begin{array}{l}\text { Dark brown to black organic sandy silt containing sand and gravel- } \\
\text { sized briquetage and common plant macrofossils throughout; charcoal } \\
\text { at 197.91; woody remains between 197.91-197.89; blocky briquetage } \\
\text { fragment at 197.89-197.86; gradual to }\end{array}$ \\
\hline $\begin{array}{l}197.86- \\
197.56\end{array}$ & $\begin{array}{l}\text { Dark grey to black organic sandy silty gravely clay containing very fine } \\
\text { plant matter and occasional sand-sized briquetage; blocky briquetage } \\
\text { between } 197.72-197.56 \text {; sharp to }\end{array}$ \\
\hline
\end{tabular}




\begin{tabular}{|l|l|}
\hline $\begin{array}{l}197.56- \\
197.28\end{array}$ & Grey sandy silty gravel; sharp to \\
\hline $\begin{array}{l}197.28- \\
197.20\end{array}$ & $\begin{array}{l}\text { Dark greyish brown organic silty clay containing dark brown organic } \\
\text { (peaty) beds at 197.25, 197.23, 197.22, 197.20, 197.21; shell bed } \\
\text { (fragments) at 197.21; gradual to }\end{array}$ \\
\hline $197.20-$ & $\begin{array}{l}\text { Dark brown organic silty clay (peaty) containing shell fragments } \\
\text { throughout and occasional fine gravel }\end{array}$ \\
\hline 197.01 & $\begin{array}{l}\text { Dark greyish brown organic silty clay (peaty) containing very fine plant } \\
\text { matter and occasional fine gravel; common Mollusca and shell } \\
\text { fragments throughout; sharp to }\end{array}$ \\
\hline $196.01-$ & $\begin{array}{l}\text { Wet light brownish grey sandy silty gravel; rounded clasts to 196.75 } \\
\text { becoming coarse angular gravel between 196.75-196.69; sharp to }\end{array}$ \\
\hline $196.88-$ & $\begin{array}{l}\text { Dark grey sandy clay; common fine plant matter and macrofossils } \\
\text { throughout; occasional fine gravel and black flecks; sharp to }\end{array}$ \\
\hline $196.69-69-39$ & $\begin{array}{l}\text { Dark greyish brown to black organic sediment (peaty sandy silty clay) } \\
\text { containing fine gravel; white fine sand lens at 196.32 }\end{array}$ \\
\hline $196.39-$ &
\end{tabular}

Table 5: BH78 (32N 324301, 5406413)

\begin{tabular}{|c|c|}
\hline $\begin{array}{l}\text { Elevation } \\
\text { (m a.s.I.) }\end{array}$ & Description \\
\hline $\begin{array}{l}201.77- \\
201.72\end{array}$ & $\begin{array}{l}\text { Grey clay containing common sand-sized briquetage fragments; } \\
\text { gradual to }\end{array}$ \\
\hline $\begin{array}{l}201.72- \\
201.63\end{array}$ & Blocky briquetage in grey clay matrix; gradual to \\
\hline $\begin{array}{l}201.63- \\
201.58\end{array}$ & $\begin{array}{l}\text { Grey clay containing common sand-sized briquetage fragments; sharp } \\
\text { to }\end{array}$ \\
\hline $\begin{array}{l}201.58- \\
201.16\end{array}$ & $\begin{array}{l}\text { Grey sandy clay rich in blocky briquetage, especially between } 201.44- \\
201.33 \text {; scattered limestone clasts down to } 201.29 \text {; occasional } \\
\text { charcoal fragments throughout; sharp to }\end{array}$ \\
\hline $\begin{array}{l}201.16- \\
201.04\end{array}$ & Continuation of above; common charcoal; sharp to \\
\hline $\begin{array}{l}201.04- \\
200.73\end{array}$ & Reddish brown and grey laminated silty clay; gradual to \\
\hline $\begin{array}{l}200.73- \\
200.63\end{array}$ & Mottled light grey wet clayey silt; gradual to \\
\hline $\begin{array}{l}200.63- \\
200.09\end{array}$ & Light grey clayey silt; sharp to \\
\hline $\begin{array}{l}200.09- \\
200.06\end{array}$ & Horizontal wood fragment (archaeology); sharp to \\
\hline $\begin{array}{l}200.06- \\
200.04\end{array}$ & $\begin{array}{l}\text { Light grey silt containing horizontally bedded decomposed woody } \\
\text { fragments (from piece above); charcoal-rich; sharp to }\end{array}$ \\
\hline $\begin{array}{l}200.04- \\
200.01\end{array}$ & Horizontal wood fragment (archaeology); sharp to \\
\hline $\begin{array}{l}200.01- \\
199.98\end{array}$ & Very dark grey to black charcoal-rich stiff clay; gradual to \\
\hline $\begin{array}{l}199.98- \\
199.78\end{array}$ & Mottled dark grey and light grey stiff clay; contact obscured \\
\hline $\begin{array}{l}199.78- \\
199.77\end{array}$ & Dark grey stiff clay containing occasional fine gravel \\
\hline $\begin{array}{l}199.77- \\
199.38\end{array}$ & $\begin{array}{l}\text { Reddish brown and grey mottled sandy gravely clay becoming } \\
\text { increasingly sandy downwards (especially below 199.50); sharp to }\end{array}$ \\
\hline 199.38- & Light grey and black mottled clay containing occasional wood \\
\hline
\end{tabular}




\begin{tabular}{|l|l|}
\hline 199.35 & fragments (1.5 cm $\times 1 \mathrm{~cm}$ in size); sharp to \\
\hline $199.35-$ & Reddish brown sandy clay; gradual to \\
199.21 & \\
\hline $199.21-$ & Reddish brown silty sand, fining downwards; sharp to \\
199.13 & \\
\hline $199.13-$ & Reddish brown clay containing common plant remains (Phragmites \\
198.95 & stems) between 199.13-199.01; sharp to \\
\hline $198.95-$ & Reddish brown silty sand; gradual to \\
198.92 & \\
\hline $198.92-$ & Reddish brown clay \\
198.77 & \\
\hline $198.77-$ & Continuation of above; gradual to \\
198.67 & \\
\hline $198.67-$ & Reddish brown sandy clay becoming silty clay downwards; gradual to \\
198.55 & \\
\hline $198.55-$ & Reddish brown sandy silty clay; gradual to \\
198.23 & \\
\hline $198.23-$ & Mottled light grey and reddish brown silty clay; gradual to \\
198.06 & \\
\hline $198.06-$ & Reddish brown silty clay; gradual to \\
197.98 & \\
\hline $197.98-$ & Reddish brown silt; gradual to \\
197.77 & \\
\hline
\end{tabular}

Table 6: BH80 (32N 324295, 5406431)

\begin{tabular}{|c|c|}
\hline $\begin{array}{l}\text { Elevation } \\
\text { (m a.s.I.) }\end{array}$ & Description \\
\hline $\begin{array}{l}201.63- \\
201.18\end{array}$ & $\begin{array}{l}\text { Dark brown silt containing common briquetage and charcoal, and } \\
\text { occasional limestone fragments (trench back-fill); sharp to }\end{array}$ \\
\hline $\begin{array}{l}201.18- \\
200.98\end{array}$ & $\begin{array}{l}\text { Light grey and reddish brown mottled clay rich in briquetage and } \\
\text { charcoal in the upper } 7 \mathrm{~cm} \text {; blocky briquetage at 201.16; gradual to }\end{array}$ \\
\hline $\begin{array}{l}200.98- \\
200.59\end{array}$ & $\begin{array}{l}\text { Reddish brown and light grey mottled silty clay rich in decomposed } \\
\text { plant matter; sharp to }\end{array}$ \\
\hline $\begin{array}{l}200.59- \\
200.27\end{array}$ & $\begin{array}{l}\text { Light grey-olive grey sticky silt rich in plant (Phragmites stem) remains } \\
\text { throughout; gradual to }\end{array}$ \\
\hline $\begin{array}{l}200.27- \\
199.69\end{array}$ & $\begin{array}{l}\text { Faintly mottled light grey sticky silt becoming dark grey downwards; } \\
\text { occasional plant (Phragmites) remains throughout }\end{array}$ \\
\hline $\begin{array}{l}199.69- \\
199.63\end{array}$ & $\begin{array}{l}\text { Continuation of above; contains } 1 \mathrm{~cm} \text { thick horizon of decomposed } \\
\text { plant matter }\end{array}$ \\
\hline $\begin{array}{l}199.63- \\
199.53\end{array}$ & $\begin{array}{l}\text { Dark brown silty clay containing common fine plant matter; occasional } \\
\text { charcoal and sand and fine gravel-sized briquetage }(\leq 0.3 \mathrm{~cm}) \text {; gradual } \\
\text { to }\end{array}$ \\
\hline $\begin{array}{l}199.53- \\
199.37\end{array}$ & $\begin{array}{l}\text { Mottled light grey silty clay containing black organic streaks, becoming } \\
\text { less frequent downwards; gradual to }\end{array}$ \\
\hline $\begin{array}{l}199.37- \\
199.08\end{array}$ & $\begin{array}{l}\text { Light grey silty clay containing occasional decomposed plant remains; } \\
\text { sharp to }\end{array}$ \\
\hline $\begin{array}{l}199.08- \\
199.06\end{array}$ & $\begin{array}{l}\text { Very light grey fine sandy silty clay containing fine sand and gravel; } \\
\text { sharp to }\end{array}$ \\
\hline $\begin{array}{l}199.06- \\
199.03\end{array}$ & $\begin{array}{l}\text { Dark brown to black organic fine sandy silty clay containing } \\
\text { decomposed plant remains }\end{array}$ \\
\hline $\begin{array}{l}199.03- \\
199.00\end{array}$ & Mottled olive grey stiff sandy silty clay containing fine gravel; sharp to \\
\hline
\end{tabular}




\begin{tabular}{|l|l|}
\hline $199.00-$ & Dark reddish brown organic fine sandy silty clay containing occasional \\
198.98 & very fine gravel $(<0.5 \mathrm{~cm}) ;$ sharp to \\
\hline $198.98-$ & Olive grey and reddish brown mottled silty clay; sharp to \\
198.96 & \\
\hline $198.96-$ & Continuation of $199.00-198.98 ;$ sharp to \\
198.955 & \\
\hline $198.955-$ & Mottled olive grey and reddish brown fine sandy silty clay containing \\
198.73 & black organic streaks; occasional plant remains; gradual to \\
\hline $198.73-$ & Reddish brown fine sandy silt containing occasional black bands and \\
198.63 & plant (Phragmites) remains \\
\hline
\end{tabular}

Table 7: BH81- L (32N 324293, 5406426)

Top $1 \mathrm{~m}$ of core (201.57-200.57 $\mathrm{m}$ a.s.l.) not retained for laboratory description

\begin{tabular}{|c|c|c|}
\hline $\begin{array}{l}\text { Elevation } \\
\text { (m a.s.I.) }\end{array}$ & Colour & Description \\
\hline $\begin{array}{l}200.57- \\
200.45\end{array}$ & $\begin{array}{l}5 Y 5 / 2 \\
\text { Olive } \\
\text { grey }\end{array}$ & $\begin{array}{l}\text { Soft silt containing } 5 Y \text { Y } 4 \text { dark grey vertical mottles (root } \\
\text { channels?), becoming dark grey silt; olive grey vertical mottles } \\
\text { below 200.49; occasional plant (Phragmites) remains } \\
\text { throughout; occasional fine sand between } 200.485-200.45 ; \\
\text { gradual to }\end{array}$ \\
\hline $\begin{array}{l}200.45- \\
200.43\end{array}$ & $\begin{array}{l}5 Y 7 / 1 \\
\text { Light } \\
\text { grey }\end{array}$ & $\begin{array}{l}\text { Soft silt containing 5Y 4/1 dark grey mottles; occasional fine } \\
\text { sand and plant (Phragmites) remains; moat fill; sharp to }\end{array}$ \\
\hline $\begin{array}{l}200.43- \\
199.99\end{array}$ & $\begin{array}{l}5 Y 4 / 1 \\
\text { Dark } \\
\text { grey }\end{array}$ & $\begin{array}{l}\text { Soft silt; faintly mottled; occasional plant (Phragmites) remains; } \\
\text { moat fill; sharp to }\end{array}$ \\
\hline $\begin{array}{l}199.99- \\
199.95\end{array}$ & $\begin{array}{l}5 Y \\
2.5 / 1 \\
\text { Black }\end{array}$ & $\begin{array}{l}\text { Gritty sandy silt containing blocky briquetage }(>2 \mathrm{~cm}) \text { and } \\
\text { occasional plant (Phragmites) remains; gradual to }\end{array}$ \\
\hline $\begin{array}{l}199.95- \\
199.89\end{array}$ & $\begin{array}{l}5 \mathrm{Y} \\
2.5 / 1 \\
\text { Black }\end{array}$ & $\begin{array}{l}\text { Peaty sandy silt rich in plant remains; bed of Phragmites stems } \\
\text { at } 199.94-199.93 \text {; briquetage pottery fragment }(1 \mathrm{~cm}) \text {; sharp to } \\
\mathbf{7 7 0 - 4 3 0} \text { cal BCE (Beta-310885): } \mathbf{1 9 9 . 9 5 - 1 9 9 . 9 4 ~ m ~ a . s . l . ~}\end{array}$ \\
\hline $\begin{array}{l}199.89- \\
199.83\end{array}$ & $\begin{array}{l}2.5 Y R \\
4 / 6 \mathrm{Red}\end{array}$ & $\begin{array}{l}\text { Blocky briquetage in wet sandy silt matrix (5Y } 2.5 / 1 \text { black); } \\
\text { sharp to }\end{array}$ \\
\hline $\begin{array}{l}199.83- \\
199.81\end{array}$ & $\begin{array}{l}5 Y 3 / 1 \\
\text { Very } \\
\text { dark } \\
\text { grey }\end{array}$ & Silty sand containing occasional blocky briquetage; sharp to \\
\hline $\begin{array}{l}199.81- \\
199.79\end{array}$ & $\begin{array}{l}5 Y 4 / 1 \\
\text { Dark } \\
\text { grey }\end{array}$ & $\begin{array}{l}\text { Soft wet sandy silt containing coarse sand and occasional } \\
\text { gravel-sized briquetage }(\leq 0.5 \mathrm{~cm}) \text {; sharp to }\end{array}$ \\
\hline $\begin{array}{l}199.79- \\
199.76\end{array}$ & $\begin{array}{l}2.5 \text { YR } \\
4 / 6 \text { Red }\end{array}$ & $\begin{array}{l}\text { Blocky briquetage fragment in } 5 Y 4 / 2 \text { olive grey wet silty } \\
\text { matrix; sharp to }\end{array}$ \\
\hline $\begin{array}{l}199.76- \\
199.71\end{array}$ & $\begin{array}{l}2.5 Y R \\
4 / 6 \text { Red }\end{array}$ & $\begin{array}{l}\text { Blocky briquetage fragment in coal-black soft silty matrix (very } \\
\text { charcoal-rich); woody fragment at } 199.72(0.5 \mathrm{~cm} \text { x } 0.5 \mathrm{~cm}) \text {; } \\
\text { sharp to }\end{array}$ \\
\hline $\begin{array}{l}199.71- \\
199.67\end{array}$ & $\begin{array}{l}\text { Coal- } \\
\text { black }\end{array}$ & $\begin{array}{l}\text { Soft clayey silt with faintly peaty texture (very charcoal rich?); } \\
\text { sharp to }\end{array}$ \\
\hline $\begin{array}{l}199.67- \\
199.65\end{array}$ & $\begin{array}{l}7.5 \mathrm{YR} \\
5 / 4 \\
\text { Brown }\end{array}$ & $\begin{array}{l}\text { Wet crumbly block of briquetage in coal-black (very charcoal } \\
\text { rich) silty matrix; sharp to }\end{array}$ \\
\hline 199.65- & Coal- & Continuation of 199.71-199.67; blocky briquetage fragment \\
\hline
\end{tabular}




\begin{tabular}{|c|c|c|}
\hline 199.60 & black & $\begin{array}{l}\text { present on surface of core at 199.63-199.61 (in-situ?); gradual } \\
\text { to }\end{array}$ \\
\hline $\begin{array}{l}199.60- \\
199.57\end{array}$ & $\begin{array}{l}5 \mathrm{Y} \\
2.5 / 1 \\
\text { Black }\end{array}$ & $\begin{array}{l}\text { Charcoal-rich silt; layer of wood (archaeology) at 199.59- } \\
199.585\end{array}$ \\
\hline $\begin{array}{l}199.57- \\
199.55\end{array}$ & $\begin{array}{l}5 Y \\
2.5 / 1 \\
\text { Black; } \\
2.5 Y \\
4 / 1 \\
\text { Dark } \\
\text { grey } \\
\end{array}$ & Organic silty clay; faintly horizontally banded; sharp to \\
\hline $\begin{array}{l}199.55- \\
199.50\end{array}$ & $\begin{array}{l}2.5 Y \\
4 / 1 \\
\text { Dark } \\
\text { grey }\end{array}$ & $\begin{array}{l}\text { Silty clay containing occasional black flecks (charcoal?); } \\
\text { briquetage fragment }(1 \mathrm{~cm}) \text { towards surface of core at } 199.54- \\
199.53 \text { (in-situ?); gradual to }\end{array}$ \\
\hline $\begin{array}{l}199.50- \\
199.48\end{array}$ & $\begin{array}{l}2.5 Y \\
4 / 1 \\
\text { Dark } \\
\text { grey }\end{array}$ & Coarse sandy clay; gradual to \\
\hline $\begin{array}{l}199.48- \\
199.45\end{array}$ & $\begin{array}{l}2.5 Y \\
4 / 1 \\
\text { Dark } \\
\text { grey; } \\
2.5 Y \\
2.5 / 1 \\
\text { Black }\end{array}$ & $\begin{array}{l}\text { Faintly horizontally banded silty clay containing occasional } \\
\text { coarse sand; gradual to }\end{array}$ \\
\hline $\begin{array}{l}199.45- \\
199.40\end{array}$ & $\begin{array}{l}2.5 Y \\
4 / 1 \\
\text { Dark } \\
\text { grey; } \\
2.5 Y \\
2.5 / 1 \\
\text { Black }\end{array}$ & Faintly horizontally banded coarse sandy clayey silt; sharp to \\
\hline $\begin{array}{l}199.40- \\
199.31\end{array}$ & $\begin{array}{l}2.5 Y \\
5 / 4 \\
\text { Light } \\
\text { olive } \\
\text { brown; } \\
2.5 Y \\
5 / 1 \\
\text { Grey }\end{array}$ & Mottled sandy silt; gradual to \\
\hline $\begin{array}{l}199.31- \\
199.18\end{array}$ & $\begin{array}{l}7.5 \mathrm{YR} \\
4 / 3 \\
\text { Brown }\end{array}$ & Sandy silt; sharp to \\
\hline $\begin{array}{l}199.18- \\
199.04\end{array}$ & $\begin{array}{l}2.5 Y \\
5 / 2 \\
\text { Greyish } \\
\text { brown }\end{array}$ & $\begin{array}{l}\text { Faintly mottled silty sand containing occasional hard woody } \\
\text { remains (twigs/stems) at } 199.13 \text { and } 199.10(0.5 \mathrm{~cm} \times 0.2 \mathrm{~cm}) \text {; } \\
\text { gradual to }\end{array}$ \\
\hline $\begin{array}{l}199.04- \\
198.77\end{array}$ & $\begin{array}{l}7.5 Y R \\
4 / 2 \\
\text { Brown; } \\
2.5 Y \\
5 / 1\end{array}$ & $\begin{array}{l}\text { Faintly mottled clay containing occasional black organic flecks; } \\
\text { occasional } 7.5 \text { YR } 5 / 4 \text { strong brown staining (Fe staining); } \\
\text { gradual to }\end{array}$ \\
\hline
\end{tabular}




\begin{tabular}{|l|l|l|}
\hline & Grey & \\
\hline $198.77-$ & $7.5 Y R$ & Sandy silty clay, becoming sandy silt downwards; common \\
198.57 & $4 / 3$ & black organic flecks throughout \\
& Brown & \\
\hline
\end{tabular}

Table 8: BH82 (32N 324294, 5406431)

\begin{tabular}{|c|c|}
\hline $\begin{array}{l}\text { Elevation } \\
\text { (m a.s.I.) }\end{array}$ & Description \\
\hline $\begin{array}{l}201.54- \\
201.23\end{array}$ & $\begin{array}{l}\text { Hard dry dark brown silty clay (pedogenically altered alluvium) containing } \\
\text { common sand and gravel-sized briquetage and occasional charcoal; } \\
\text { modern roots; sharp to }\end{array}$ \\
\hline $\begin{array}{l}201.23- \\
201.11\end{array}$ & $\begin{array}{l}\text { Faintly mottled reddish brown clay containing occasional decomposed } \\
\text { plant matter; sharp to }\end{array}$ \\
\hline $\begin{array}{l}201.11- \\
201.10\end{array}$ & Continuation of 201.54-201.23; sharp to \\
\hline $\begin{array}{l}201.10- \\
200.88\end{array}$ & Continuation of 201.23-201.11; sharp to \\
\hline $\begin{array}{l}200.88- \\
200.78\end{array}$ & $\begin{array}{l}\text { Dry silty clay rich in gravel-sized and blocky briquetage }(\leq 2.5 \mathrm{~cm} \text { ) } \\
\text { (briquetage not in-situ); sharp to }\end{array}$ \\
\hline $\begin{array}{l}200.78- \\
200.58\end{array}$ & $\begin{array}{l}\text { Mottled reddish brown and light grey stiff clay containing occasional black } \\
\text { organic bands; bands of decomposed plant matter at } 200.77 \text { and } 200.73- \\
200.68 \text {; sharp to }\end{array}$ \\
\hline $\begin{array}{l}200.58- \\
200.54\end{array}$ & Light grey silty clay containing common plant (Phragmites) remains \\
\hline $\begin{array}{l}200.54- \\
200.49\end{array}$ & $\begin{array}{l}\text { Mottled light olive grey and dark grey fine sandy silt containing oyster } \\
\text { shell fragments and common plant remains; sharp to }\end{array}$ \\
\hline $\begin{array}{l}200.49- \\
200.30\end{array}$ & $\begin{array}{l}\text { Mottled dark grey and light grey soft silt containing occasional fine } \\
\text { decomposed plant matter and small shell fragments; sharp to }\end{array}$ \\
\hline $\begin{array}{l}200.30- \\
199.84\end{array}$ & Dark grey clayey silt; sharp to \\
\hline $\begin{array}{l}199.84- \\
199.79\end{array}$ & $\begin{array}{l}\text { Horizontally bedded black organic sandy gravely silt }(0.3-2 \mathrm{~cm}) \\
\text { containing common fine decomposed plant matter; woody stem }(2.5 \mathrm{~cm} \\
\text { long) at } 199.80 \text {; sharp to }\end{array}$ \\
\hline $\begin{array}{l}199.79- \\
199.76\end{array}$ & $\begin{array}{l}\text { Light grey silty clay lens in black organic silt; occasional decomposed } \\
\text { plant remains; sharp to }\end{array}$ \\
\hline $\begin{array}{l}199.76- \\
199.67\end{array}$ & $\begin{array}{l}\text { Black silty clay rich in very fine charcoal; briquetage fragment }(2 \mathrm{~cm} \times 0.5 \\
\mathrm{cm}) \text { at } 199.74-199.72 \text {; transition from silty clay to clay at } 199.72 \text {; sharp to }\end{array}$ \\
\hline $\begin{array}{l}199.67- \\
199.50\end{array}$ & $\begin{array}{l}\text { Mottled black and dark grey clay containing black flecks (possibly } \\
\text { charcoal); gradual to }\end{array}$ \\
\hline $\begin{array}{l}199.50- \\
199.41\end{array}$ & $\begin{array}{l}\text { Mottled light olive grey, black and reddish brown clay containing coarse } \\
\text { sand/fine gravel and occasional decomposed plant remains; gradual to }\end{array}$ \\
\hline $\begin{array}{l}199.41- \\
199.14\end{array}$ & $\begin{array}{l}\text { Mottled light olive grey and reddish brown sandy silty clay containing } \\
\text { coarse sand/fine gravel and occasional black (organic) flecks; gradual to }\end{array}$ \\
\hline $\begin{array}{l}199.14- \\
198.94\end{array}$ & $\begin{array}{l}\text { Faintly mottled reddish brown and light olive grey sandy silty clay } \\
\text { containing occasional black (organic) flecks and common fine plant } \\
\text { matter; gradual to }\end{array}$ \\
\hline $\begin{array}{l}198.94- \\
198.91\end{array}$ & $\begin{array}{l}\text { Reddish brown clay-rich sand containing occasional plant remains; } \\
\text { gradual to }\end{array}$ \\
\hline $\begin{array}{l}198.91- \\
198.85\end{array}$ & $\begin{array}{l}\text { Reddish brown sandy clay containing sparse fine gravel and occasional } \\
\text { black (organic) flecks; gradual to }\end{array}$ \\
\hline $\begin{array}{l}198.85- \\
198.79\end{array}$ & Mottled olive grey and reddish brown sandy clay; gradual to \\
\hline
\end{tabular}




\begin{tabular}{|l|l|}
\hline $198.79-$ & Reddish brown silty sand containing vertical root; gradual to \\
198.74 & \\
\hline $198.74-$ & Reddish brown stiff sandy clay; gradual to \\
198.70 & \\
\hline $198.70-$ & Reddish brown silty sand containing occasional plant remains; gradual to \\
198.67 & \\
\hline $198.67-$ & Reddish brown stiff sandy clay containing black (organic) flecks \\
198.54 & \\
\hline
\end{tabular}

Table 9: BH87 (32N 324182, 5406432$)$

\begin{tabular}{|c|c|}
\hline $\begin{array}{l}\text { Elevation } \\
\text { (m a.s.I.) }\end{array}$ & Description \\
\hline $\begin{array}{l}201.97- \\
201.87\end{array}$ & $\begin{array}{l}\text { Dark brown silt containing modern roots and sand-sized briquetage } \\
\text { (pedogenically altered alluvium); sharp to }\end{array}$ \\
\hline $\begin{array}{l}201.87- \\
201.41\end{array}$ & $\begin{array}{l}\text { Mottled reddish brown clay containing common gravel-sized briquetage } \\
\text { (up to } 1 \mathrm{~cm} \text { ) and charcoal fragments; modern roots down to 201.62; } \\
\text { gradual to }\end{array}$ \\
\hline $\begin{array}{l}201.41- \\
201.31\end{array}$ & $\begin{array}{l}\text { Faintly mottled reddish brown silt containing common decomposed plant } \\
\text { remains; gradual to }\end{array}$ \\
\hline $\begin{array}{l}201.31- \\
201.04\end{array}$ & $\begin{array}{l}\text { Mottled reddish brown and grey silt containing occasional decomposed } \\
\text { plant remains; gradual to }\end{array}$ \\
\hline $\begin{array}{l}201.04- \\
200.97\end{array}$ & Grey silt containing common plant matter; core expanded \\
\hline $\begin{array}{l}200.97- \\
200.90\end{array}$ & $\begin{array}{l}\text { Grey silt containing common plant (Phragmites) remains; layer of fine } \\
\text { sand at } 200.90(\sim 0.3 \mathrm{~cm} \text { thick); sharp to }\end{array}$ \\
\hline $\begin{array}{l}200.90- \\
200.62\end{array}$ & $\begin{array}{l}\text { Dark grey faintly mottled organic silt containing common laminated plant } \\
\text { remains; sharp to }\end{array}$ \\
\hline $\begin{array}{l}200.62- \\
200.61\end{array}$ & Light grey silt; sharp to \\
\hline $\begin{array}{l}200.61- \\
200.42\end{array}$ & $\begin{array}{l}\text { Dark brownish grey organic silt rich in woody plant remains; occasional } \\
\text { mollusc shells; sharp to }\end{array}$ \\
\hline $\begin{array}{l}200.42- \\
200.41\end{array}$ & Dark grey silt; sharp to \\
\hline $\begin{array}{l}200.41- \\
199.90\end{array}$ & $\begin{array}{l}\text { Grey silt containing common plant remains and occasional mollusc shells; } \\
\text { large bone fragment }(4 \mathrm{~cm} \times 1 \mathrm{~cm}) \text { at } 200.32-200.31 \text {; woody fragment at } \\
204 \text {; sharp to }\end{array}$ \\
\hline $\begin{array}{l}199.90- \\
199.60\end{array}$ & $\begin{array}{l}\text { Mottled grey and black silty clay containing common clay pellets and } \\
\text { black charcoal-rich flecks/streaks; occasional fine gravel-sized briquetage } \\
(\leq 0.5 \mathrm{~cm}) \text {, fine gravel and plant remains; sharp to }\end{array}$ \\
\hline $\begin{array}{l}199.60- \\
198.97\end{array}$ & $\begin{array}{l}\text { Reddish brown to grey silty clay becoming greyer towards base; common } \\
\text { sand-sized briquetage and plant remains; occasional shell fragments and } \\
\text { gravel; occasional gravel-sized briquetage and charcoal throughout, most } \\
\text { frequent between } 199.60-199.47 \text { becoming sparser downwards; large } \\
\text { bone fragment ( } 3 \mathrm{~cm} \times 1.5 \mathrm{~cm}) \text { at } 199.02\end{array}$ \\
\hline $\begin{array}{l}198.97- \\
198.52\end{array}$ & $\begin{array}{l}\text { Dark grey silty clay containing sparse plant remains and shell fragments; } \\
\text { sparse sand-sized briquetage and charcoal down to 198.58; sharp to }\end{array}$ \\
\hline $\begin{array}{l}198.52- \\
198.48\end{array}$ & Light grey silt; sharp to \\
\hline $\begin{array}{l}198.48- \\
197.97\end{array}$ & $\begin{array}{l}\text { Dark grey sandy gravely silt containing common plant remains and fine } \\
\text { gravel; charcoal fragments at } 198.33 \text {; blocky briquetage }(3 \mathrm{~cm} \times 3 \mathrm{~cm}) \text { at } \\
\text { 198.06-198.03 (part of briquette) surrounded by smaller blocky and } \\
\text { gravel-sized briquetage - typologically dated to Hallstatt D1 }\end{array}$ \\
\hline
\end{tabular}


Table 10: BH88-L (32N 324178, 5406417)

\begin{tabular}{|c|c|c|}
\hline $\begin{array}{l}\text { Elevation } \\
\text { (m a.s.I.) }\end{array}$ & Colour & Description \\
\hline $\begin{array}{l}201.99- \\
201.84\end{array}$ & $\begin{array}{l}7.5 Y R \\
2.5 / 2 \\
\text { Very } \\
\text { dark } \\
\text { brown }\end{array}$ & $\begin{array}{l}\text { Silty clay (pedogenically altered alluvium) containing modern } \\
\text { roots and sparse sand and fine gravel-sized briquetage }(\leq 0.2 \\
\mathrm{cm}) \text {; sharp to }\end{array}$ \\
\hline $\begin{array}{l}201.84- \\
201.40\end{array}$ & $\begin{array}{l}7.5 Y R \\
4 / 3 \\
\text { Brown }\end{array}$ & $\begin{array}{l}\text { Stiff clay containing sand and gravel-sized briquetage }(\leq 0.8 \\
\mathrm{cm}) \text {; modern roots down to } 201.41 \text {; rich in blocky briquetage } \\
\text { between } 201.59-201.51 \text { and } 201.48-201.43 \text {; small charcoal } \\
\text { fragment at } 201.56(0.2 \mathrm{~cm}) \text {; sharp to }\end{array}$ \\
\hline $\begin{array}{l}201.40- \\
201.35\end{array}$ & $\begin{array}{l}7.5 \mathrm{YR} \\
4 / 3 \\
\text { Brown }\end{array}$ & $\begin{array}{l}\text { Faintly mottled clay containing occasional sand and } \\
\text { decomposed plant remains; sharp to }\end{array}$ \\
\hline $\begin{array}{l}201.35- \\
201.34\end{array}$ & $\begin{array}{l}\text { 7.5YR } \\
2.5 / 1 \\
\text { Black }\end{array}$ & Peat; sharp to \\
\hline $\begin{array}{l}201.34- \\
201.16\end{array}$ & $\begin{array}{l}7.5 \mathrm{YR} \\
4 / 3 \\
\text { Brown }\end{array}$ & $\begin{array}{l}\text { Faintly mottled silty clay with peaty inclusions (not in-situ) at } \\
201.31,201.30-201.27 \text { and } 201.25 \text {; sparse sand-sized } \\
\text { briquetage throughout; occasional fine plant matter below } \\
201.22 \text {; gradual to }\end{array}$ \\
\hline $\begin{array}{l}201.16- \\
201.01\end{array}$ & $\begin{array}{l}7.5 \mathrm{YR} \\
4 / 2 \\
\text { Brown }\end{array}$ & $\begin{array}{l}\text { Faintly mottled clayey silt containing common decomposed } \\
\text { and fine plant matter; very sparse fine charcoal at } 201.13 \text { and } \\
\text { 201.04; woody remains at 201.05; gradual to }\end{array}$ \\
\hline $\begin{array}{l}201.01- \\
200.98\end{array}$ & $\begin{array}{l}\text { 7.5YR } \\
\text { 4/1 Dark } \\
\text { grey }\end{array}$ & Silt rich in plant remains; occasional fine shell fragments \\
\hline $\begin{array}{l}200.98- \\
200.56\end{array}$ & $\begin{array}{l}\text { 7.5YR } \\
\text { 4/1 Dark } \\
\text { grey; } \\
\text { 7.5YR } \\
\text { 6/1 Grey }\end{array}$ & $\begin{array}{l}\text { Mottled organic silt; visible sand beds at 200.92-200.91, } \\
200.667-200.665,200.657-200.655,200.647-200.646 \text {, } \\
\text { 200.631-200.63, 200.606-200.604 and 200.591-200.589; } \\
\text { common plant remains (including Phragmites) throughout; } \\
\text { plant-rich beds at 200.94, 200.92-200.91, 200.586-200.584 } \\
\text { and } 200.576-200.571 \text {; sharp to }\end{array}$ \\
\hline $\begin{array}{l}200.56- \\
200.49\end{array}$ & $\begin{array}{l}\text { 7.5YR } \\
\text { 4/1 Dark } \\
\text { grey }\end{array}$ & $\begin{array}{l}\text { Organic fine sandy silt rich in fine plant matter and } \\
\text { Phragmites; woody fragment at } 200.55 \text {; gradual to }\end{array}$ \\
\hline $\begin{array}{l}200.49- \\
200.44\end{array}$ & $\begin{array}{l}\text { 7.5YR } \\
3 / 1 \text { Very } \\
\text { dark } \\
\text { grey }\end{array}$ & $\begin{array}{l}\text { Organic silty clay containing occasional fine plant remains; } \\
\text { sparse coarse sand; sparse sand-sized briquetage; sharp to }\end{array}$ \\
\hline $\begin{array}{l}200.44- \\
200.39\end{array}$ & $\begin{array}{l}\text { 7.5YR } \\
3 / 1 \text { Very } \\
\text { dark } \\
\text { grey }\end{array}$ & $\begin{array}{l}\text { Organic silty clay containing common sand and gravel-sized } \\
\text { briquetage; occasional fine plant matter and coarse sand; } \\
\text { sharp to }\end{array}$ \\
\hline $\begin{array}{l}200.39- \\
200.29\end{array}$ & $\begin{array}{l}\text { 7.5YR } \\
\text { 4/1 Dark } \\
\text { grey }\end{array}$ & $\begin{array}{l}\text { Organic silty clay containing occasional fine plant matter; } \\
\text { sparse fine sand; sparse sand-sized briquetage down to } \\
200.29 \text {, becoming common below this; gradual to }\end{array}$ \\
\hline
\end{tabular}




\begin{tabular}{|c|c|c|}
\hline $\begin{array}{l}200.29- \\
199.99\end{array}$ & $\begin{array}{l}\text { 7.5YR } \\
\text { 4/1 Dark } \\
\text { grey }\end{array}$ & $\begin{array}{l}\text { Silty clay containing common black flecks and plant matter; } \\
\text { occasional sand and fine gravel-sized briquetage }(\leq 0.3 \mathrm{~cm}) \text {; } \\
\text { very sparse coarse sand; becomes fine sandy silty clay below } \\
200.06\end{array}$ \\
\hline $\begin{array}{l}199.99- \\
199.45\end{array}$ & $\begin{array}{l}\text { 7.5YR } \\
\text { 4/1 Dark } \\
\text { grey }\end{array}$ & $\begin{array}{l}\text { Silty clay rich in fine plant matter; common sand-sized } \\
\text { briquetage; occasional fine gravel/coarse sand; sharp to }\end{array}$ \\
\hline $\begin{array}{l}199.45- \\
199.42\end{array}$ & $\begin{array}{l}\text { 7.5YR } \\
\text { 4/1 Dark } \\
\text { grey }\end{array}$ & $\begin{array}{l}\text { Wet sandy silty clay containing well preserved Phragmites } \\
\text { stem; sharp to }\end{array}$ \\
\hline $\begin{array}{l}199.42- \\
199.04\end{array}$ & $\begin{array}{l}\text { 7.5YR } \\
\text { 4/1 Dark } \\
\text { grey }\end{array}$ & $\begin{array}{l}\text { Silty clay rich in fine plant matter; occasional fine } \\
\text { gravel/coarse sand; gradual to }\end{array}$ \\
\hline $\begin{array}{l}199.04- \\
198.99\end{array}$ & $\begin{array}{l}\text { 7.5YR } \\
\text { 3/1 Very } \\
\text { dark } \\
\text { grey }\end{array}$ & $\begin{array}{l}\text { Silty clay containing common charcoal flecks }(\leq 0.1 \mathrm{~cm}) \text {, } \\
\text { sparse sand-sized briquetage and occasional fine plant } \\
\text { remains; charcoal fragment at } 199.03(0.5 \mathrm{~cm} \times 0.2 \mathrm{~cm})\end{array}$ \\
\hline $\begin{array}{l}198.99- \\
198.82\end{array}$ & $\begin{array}{l}\text { 7.5YR } \\
3 / 1 \text { Very } \\
\text { dark } \\
\text { grey }\end{array}$ & $\begin{array}{l}\text { Sandy silt containing occasional fine plant matter and sparse } \\
\text { coarse sand; very sparse sand-sized briquetage between } \\
\text { 198.95-198.92; charcoal fragments at } 198.95,198.93 \text { and } \\
\text { 198.90; gradual to }\end{array}$ \\
\hline $\begin{array}{l}198.82- \\
198.70\end{array}$ & $\begin{array}{l}\text { 5YR 3/1 } \\
\text { Very } \\
\text { dark } \\
\text { grey }\end{array}$ & $\begin{array}{l}\text { Sandy silt containing occasional plant (Phragmites) remains } \\
\text { and charcoal fragments }(\leq 5 \mathrm{~mm}) \text {; sand-sized briquetage } \\
\text { fragment at 198.78; gradual to }\end{array}$ \\
\hline $\begin{array}{l}198.70- \\
198.64\end{array}$ & $\begin{array}{l}5 Y R 3 / 1 \\
\text { Very } \\
\text { dark } \\
\text { grey }\end{array}$ & Silt; gradual to \\
\hline $\begin{array}{l}198.64- \\
198.60\end{array}$ & $\begin{array}{l}5 \text { YR } 3 / 1 \\
\text { Very } \\
\text { dark } \\
\text { grey }\end{array}$ & $\begin{array}{l}\text { Silty sand containing common very fine charcoal flecks }(\leq 1 \\
\mathrm{mm}) \text {; Gley } 5 / 1 \text { greenish grey horizontal silt lens at } 198.635- \\
198.63(0.5 \mathrm{~cm} \times 2 \mathrm{~cm}) \text {; gradual to }\end{array}$ \\
\hline $\begin{array}{l}198.60- \\
198.06\end{array}$ & $\begin{array}{l}\text { 5YR } 3 / 1 \\
\text { Very } \\
\text { dark } \\
\text { grey }\end{array}$ & $\begin{array}{l}\text { Silt containing common plant remains; occasional coarse } \\
\text { sand; sparse fine gravel and fine shell fragments; charcoal } \\
\text { fragment at } 198.34(0.5 \mathrm{~cm} \times 0.2 \mathrm{~cm}) \text {; sub-angular gravel } \\
\text { clast }(0.5 \mathrm{~cm}) \text { and clast of dried clay (unfired briquetage?) } \\
(0.5 \mathrm{~cm}) \text { at } 198.11 ; \text { gradual to }\end{array}$ \\
\hline $\begin{array}{l}198.06- \\
197.99\end{array}$ & $\begin{array}{l}7.5 Y R \\
2.5 / 1 \\
\text { Black }\end{array}$ & $\begin{array}{l}\text { Sandy silt containing common coarse sand and fine plant } \\
\text { matter; diagonally orientated angular shard of bone at } \\
198.05-198.03(3 \mathrm{~cm} \times 1 \mathrm{~cm}) \text {; charcoal fragment at } 198(0.5 \\
\mathrm{cm} \times 0.2 \mathrm{~cm}) \text {; sand-rich between } 198.03-198.01 \text {, becoming } \\
\text { sandy silty gravel at this depth }\end{array}$ \\
\hline $\begin{array}{l}197.99- \\
197.78\end{array}$ & $\begin{array}{l}2.5 Y 3 / 1 \\
\text { Very } \\
\text { dark } \\
\text { grey }\end{array}$ & $\begin{array}{l}\text { Sandy silt containing common plant matter, including wood at } \\
197.89-197.88 \text { (up to } 2 \mathrm{~cm} \times 1 \mathrm{~cm} \text { ); occasional coarse } \\
\text { sand/fine gravel; very sparse fine shell fragments; charcoal } \\
\text { fragment at } 197.83(0.5 \mathrm{~cm} \times 0.2 \mathrm{~cm} \text { ); sharp to } \\
\mathbf{2 5 7 0 - 2 3 1 0 ~ c a l ~ B C E ~ ( B e t a - 3 1 0 8 8 7 ) : ~} \mathbf{1 9 7 . 8 0 - 1 9 7 . 7 8 ~ m ~ a . s . l . ~}\end{array}$ \\
\hline $\begin{array}{l}197.78- \\
197.58\end{array}$ & $\begin{array}{l}2.5 Y 4 / 1 \\
\text { Dark } \\
\text { grey }\end{array}$ & $\begin{array}{l}\text { Sandy gravel (angular and sub-angular) containing } \\
\text { occasional fine shell fragments; sharp to }\end{array}$ \\
\hline $\begin{array}{l}197.58- \\
197.39\end{array}$ & $\begin{array}{l}2.5 Y 4 / 1 \\
\text { Dark } \\
\text { grey }\end{array}$ & $\begin{array}{l}\text { Silty gravely sand containing common woody remains (up to } \\
1 \mathrm{~cm} \times 0.5 \mathrm{~cm} \text { ) and common Mollusca; sharp to }\end{array}$ \\
\hline
\end{tabular}




\begin{tabular}{|l|l|l|}
\hline $\begin{array}{l}197.39- \\
197.27\end{array}$ & $\begin{array}{l}2.5 \mathrm{Y} 3 / 1 \\
\text { Very } \\
\text { dark } \\
\text { grey }\end{array}$ & $\begin{array}{l}\text { Sandy silt containing common woody remains (up to 4 cm x } 2 \\
\text { cm) and occasional fine shell fragments; sharp to } \\
\mathbf{1 6 8 0 - 1 5 2 0} \text { cal BCE (Beta-310888): 197.39-197.35 m a.s.I. }\end{array}$ \\
\hline $\begin{array}{l}\text { 197.27- } \\
197.15\end{array}$ & $\begin{array}{l}\text { D.5Y 4/1 } \\
\text { Dark } \\
\text { grey }\end{array}$ & $\begin{array}{l}\text { Silty gravely sand containing occasional fine shell fragments; } \\
\text { sharp to } \\
\mathbf{9 6 6 0 - 9 2 9 0} \text { cal BCE (Beta-310889): 197.15-197.13 m a.s.l. }\end{array}$ \\
\hline $\begin{array}{l}\text { 197.15- } \\
196.99\end{array}$ & $\begin{array}{l}\text { 2.5Y 4/3 } \\
\text { Olive } \\
\text { brown }\end{array}$ & $\begin{array}{l}\text { Silty sand containing common plant remains and Mollusca } \\
\text { (whole and broken shells) }\end{array}$ \\
\hline
\end{tabular}

Table 11: BH97 (32N 324245, 5406386)

\begin{tabular}{|c|c|}
\hline $\begin{array}{l}\text { Elevation } \\
\text { (m a.s.I.) }\end{array}$ & Description \\
\hline $\begin{array}{l}202.39- \\
202.00\end{array}$ & $\begin{array}{l}\text { Dark brown dry crumbly silt containing modern roots (pedogenically } \\
\text { altered alluvium); blocky briquetage fragment between 202.22-202.15; } \\
\text { contact obscured }\end{array}$ \\
\hline $\begin{array}{l}202.00- \\
201.59\end{array}$ & $\begin{array}{l}\text { Stiff reddish brown clay containing common briquetage and charcoal; } \\
\text { blocky briquetage at } 202.00-201.97 \text { and } 201.90-201.88 \text {; gradual to }\end{array}$ \\
\hline $\begin{array}{l}201.59- \\
201.50\end{array}$ & $\begin{array}{l}\text { Grey clay containing common sand-sized briquetage; occasional shell } \\
\text { fragments; sharp to }\end{array}$ \\
\hline $\begin{array}{l}201.50- \\
201.39\end{array}$ & Reddish brown sandy silt rich in sand and gravel-sized briquetage \\
\hline $\begin{array}{l}201.39- \\
200.83\end{array}$ & $\begin{array}{l}\text { Brownish grey sandy gravely silt rich in briquetage and charcoal; } \\
\text { blocky briquetage at } 201.39-201.29 \text { and } 201.15-201.10 \text {; blocky } \\
\text { briquetage at } 201.10-201.04 \text { and } 200.91-200.83 \text {; contact obscured }\end{array}$ \\
\hline $\begin{array}{l}200.83- \\
200.60\end{array}$ & $\begin{array}{l}\text { Reddish brown silty gravely sand containing common charcoal and } \\
\text { sand-sized briquetage; sharp to }\end{array}$ \\
\hline $\begin{array}{l}200.60- \\
200.39\end{array}$ & $\begin{array}{l}\text { Dark greyish brown wet sandy gravely silt rich in charcoal; occasional } \\
\text { sand-sized briquetage }\end{array}$ \\
\hline $\begin{array}{l}200.39- \\
199.39\end{array}$ & $\begin{array}{l}\text { Wet slurry of briquetage and charcoal in dark greyish brown sandy } \\
\text { gravely silt; blocky briquetage throughout together with sand and } \\
\text { gravel-sized briquetage; charcoal-rich layers at 199.99-199.89 and } \\
\text { 199.74-199.64 }\end{array}$ \\
\hline $\begin{array}{l}199.39- \\
199.29\end{array}$ & Blocky briquetage in wet brown sandy silty matrix; gradual to \\
\hline $\begin{array}{l}199.29- \\
198.65\end{array}$ & $\begin{array}{l}\text { Wet brown sandy gravely silt rich in blocky briquetage and charcoal; } \\
\text { sharp to }\end{array}$ \\
\hline $\begin{array}{l}198.65- \\
198.55\end{array}$ & $\begin{array}{l}\text { Dark greyish black sandy gravely silt rich in gravel-sized briquetage } \\
\text { and woody remains; sharp to }\end{array}$ \\
\hline $\begin{array}{l}198.55- \\
198.39\end{array}$ & $\begin{array}{l}\text { Wet dark brown sandy gravely silt rich in blocky briquetage and } \\
\text { charcoal }\end{array}$ \\
\hline $\begin{array}{l}198.39- \\
198.18\end{array}$ & Reddish orange blocky briquetage; sharp to \\
\hline $\begin{array}{l}198.18- \\
198.06\end{array}$ & $\begin{array}{l}\text { Dark greyish brown wet sandy gravely silt containing common sand } \\
\text { and gravel-sized briquetage; blocky briquetage between 198.15- } \\
198.11 \text {, becoming gravel-sized below this; sharp to }\end{array}$ \\
\hline $\begin{array}{l}198.06- \\
198.05\end{array}$ & $\begin{array}{l}\text { Dark greyish brown organic sandy silt rich in decomposed plant } \\
\text { remains (peaty); sharp to }\end{array}$ \\
\hline $\begin{array}{l}198.05- \\
197.92\end{array}$ & $\begin{array}{l}\text { Organic light brownish grey fine sandy silty clay containing occasional } \\
\text { decomposed plant remains; Fe nodules and olive-grey silty inclusions } \\
\text { below 198.04; sharp to }\end{array}$ \\
\hline
\end{tabular}




\begin{tabular}{|l|l|}
\hline $\begin{array}{l}197.92- \\
197.75\end{array}$ & $\begin{array}{l}\text { Light brownish grey sandy silt containing common fine plant remains; } \\
\text { gradual to }\end{array}$ \\
\hline $\begin{array}{l}197.75- \\
197.70\end{array}$ & Reddish brown sandy silt containing common Fe nodules; gradual to \\
\hline $\begin{array}{l}197.70- \\
197.39\end{array}$ & $\begin{array}{l}\text { Reddish orange gravely silty sand containing common fine gravel and } \\
\text { occasional decomposed plant remains }\end{array}$ \\
\hline
\end{tabular}

Table 12a: BH99 (field description) (32N 324234, 5406361)

Top 4 metres of core (202.66-198.66 m a.s.I.) described in the field. Bottom $1 \mathrm{~m}$ of core (198.66-197.66 $\mathrm{m}$ a.s.I.) retained for laboratory description and radiocarbon dating (Table 12b).

\begin{tabular}{|c|c|}
\hline $\begin{array}{l}\text { Elevation } \\
\text { (m a.s.I.) }\end{array}$ & Description \\
\hline $\begin{array}{l}202.66- \\
202.39\end{array}$ & $\begin{array}{l}\text { Brown crumbly silty clay containing modern roots (pedogenically } \\
\text { altered alluvium); common sand and gravel-sized briquetage below } \\
202.55 \text {; gradual to }\end{array}$ \\
\hline $\begin{array}{l}202.39- \\
202.02\end{array}$ & $\begin{array}{l}\text { Brownish grey stiff clay containing modern roots (pedogenically } \\
\text { altered alluvium); common sand and gravel-sized briquetage; blocky } \\
\text { briquetage fragment at 202.06-202.02; sharp to }\end{array}$ \\
\hline $\begin{array}{l}202.02- \\
201.99\end{array}$ & $\begin{array}{l}\text { Dark greyish brown silt containing common charcoal and sand and } \\
\text { gravel-sized briquetage; sharp to }\end{array}$ \\
\hline $\begin{array}{l}201.99- \\
201.77\end{array}$ & $\begin{array}{l}\text { Reddish orange compact blocky briquetage and occasional charcoal; } \\
\text { sharp to }\end{array}$ \\
\hline $\begin{array}{l}201.77- \\
201.73\end{array}$ & Light brownish yellow clay containing sand-sized briquetage; sharp to \\
\hline $\begin{array}{l}201.73- \\
201.69\end{array}$ & Continuation of 201.99-201.77; sharp to \\
\hline $\begin{array}{l}201.69- \\
201.64\end{array}$ & $\begin{array}{l}\text { Brown crumbly silt rich in sand and gravel-sized briquetage and } \\
\text { charcoal; sharp to }\end{array}$ \\
\hline $\begin{array}{l}201.64- \\
201.15\end{array}$ & $\begin{array}{l}\text { Reddish orange compact blocky briquetage (crumbling) and large } \\
\text { charcoal fragments (branches) } 3 \mathrm{~cm} \times 0.2 \mathrm{~cm} \text { in size; sharp to }\end{array}$ \\
\hline $\begin{array}{l}201.15- \\
201.09\end{array}$ & $\begin{array}{l}\text { Yellowish brown silt containing common charcoal and sand-sized } \\
\text { briquetage; sharp to }\end{array}$ \\
\hline $\begin{array}{l}201.09- \\
201.06\end{array}$ & Continuation of $201.64-201.15$; sharp to \\
\hline $\begin{array}{l}201.06- \\
201.04\end{array}$ & Grey silt containing common charcoal; sharp to \\
\hline $\begin{array}{l}201.04- \\
200.84\end{array}$ & $\begin{array}{l}\text { Dark brownish black and light brown mottled sandy gravely silt rich in } \\
\text { charcoal and common sand and gravel-sized briquetage; sharp to }\end{array}$ \\
\hline $\begin{array}{l}200.84- \\
200.66\end{array}$ & Blocky briquetage in brownish grey sandy gravely silt matrix \\
\hline $\begin{array}{l}200.66- \\
199.82\end{array}$ & $\begin{array}{l}\text { Wet blocky briquetage in brown silty matrix; bone fragment at } 200.62 \text {; } \\
\text { occasional charcoal; briquetage less frequent below } 200.30 \text {; sharp to }\end{array}$ \\
\hline $\begin{array}{l}199.82- \\
199.66\end{array}$ & $\begin{array}{l}\text { Very dark greyish black organic sandy silt rich in sand and gravel- } \\
\text { sized briquetage; increasingly organic towards base }\end{array}$ \\
\hline $\begin{array}{l}199.66- \\
199.45\end{array}$ & Compact briquetage; sharp to \\
\hline $\begin{array}{l}199.45- \\
198.95\end{array}$ & $\begin{array}{l}\text { Very dark greyish black organic sandy silt rich in charcoal; common } \\
\text { sand and gravel-sized briquetage; sharp to }\end{array}$ \\
\hline $\begin{array}{l}198.95- \\
198.85\end{array}$ & Blocky briquetage; sharp to \\
\hline
\end{tabular}


Table 12b: BH99-L (laboratory description) (32N 324234, 5406361)

\begin{tabular}{|l|l|l|}
\hline $\begin{array}{l}\text { Elevation } \\
\text { (m a.s.I.) }\end{array}$ & Colour & Description \\
\hline $\begin{array}{l}198.66- \\
198.15\end{array}$ & $\begin{array}{l}\text { 5YR4/4 } \\
\text { Reddish } \\
\text { brown }\end{array}$ & $\begin{array}{l}\text { Clast-supported briquetage in a gritty earthy clayey sand } \\
\text { matrix; massive (structureless), compact; well-marked } \\
\text { transition to }\end{array}$ \\
\hline $\begin{array}{l}198.15- \\
197.95\end{array}$ & $\begin{array}{l}\text { Very } \\
\text { dark } \\
\text { grey to } \\
\text { black }\end{array}$ & $\begin{array}{l}\text { Matrix-supported briquetage in a gritty sandy matrix; massive } \\
\text { (structureless), less compact than overlying unit; abundant } \\
\text { charcoal; well-marked/sharp contact with }\end{array}$ \\
\hline $\begin{array}{l}\text { 197.95- } \\
197.87\end{array}$ & $\begin{array}{l}\text { Dark } \\
\text { grey }\end{array}$ & $\begin{array}{l}\text { Granule-rich medium to coarse sand; massive } \\
\text { (structureless); scattered detrital plant remains; very } \\
\text { scattered fragments of mollusc shell; very sharp contact } \\
\text { 1940-1700 cal BCE (Beta-310890): 197.93-197.89 m a.s.I. }\end{array}$ \\
\hline $\begin{array}{l}197.87- \\
197.66\end{array}$ & $\begin{array}{l}2.5 Y 4 / 3 \\
\text { Olive } \\
\text { brown }\end{array}$ & $\begin{array}{l}\text { Sandy clay packed with small (granule to fine gravel) clasts } \\
\text { comprising a wide variety of rock types, including well-rolled, } \\
\text { sub-angular and angular clasts of clay and mudstone, and } \\
\text { angular to well-rolled clasts of a harder rock types; massive } \\
\text { (structureless), compact }\end{array}$ \\
\hline
\end{tabular}

Table 13: BH100 (32N 324235, 5406385)

\begin{tabular}{|c|c|}
\hline $\begin{array}{l}\text { Elevation } \\
\text { (m a.s.I.) }\end{array}$ & Description \\
\hline $\begin{array}{l}202.66- \\
202.17\end{array}$ & $\begin{array}{l}\text { Dark brown silty clay containing modern roots and common gravel-sized } \\
\text { briquetage (pedogenically altered alluvium); sharp to }\end{array}$ \\
\hline $\begin{array}{l}202.17- \\
201.80\end{array}$ & Sandstone and limestone rubble (hard core); sharp to \\
\hline $\begin{array}{l}201.80- \\
201.77\end{array}$ & Blocky briquetage; sharp to \\
\hline $\begin{array}{l}201.77- \\
201.75\end{array}$ & Yellow fine sand; sharp to \\
\hline $\begin{array}{l}201.75- \\
201.66\end{array}$ & $\begin{array}{l}\text { Mottled yellowish brown sandy clay rich in sand and gravel-sized } \\
\text { briquetage; blocky briquetage at base }\end{array}$ \\
\hline $\begin{array}{l}201.66- \\
201.48\end{array}$ & $\begin{array}{l}\text { Reddish brown and grey mottled silty gravely clay containing occasional } \\
\text { blocky briquetage and charcoal; occasional fine gravel; freshwater } \\
\text { mollusc shell at } 201.53 \text {; sharp to }\end{array}$ \\
\hline $\begin{array}{l}201.48- \\
201.42\end{array}$ & Reddish brown silty clay; contact obscured \\
\hline $\begin{array}{l}201.42- \\
201.19\end{array}$ & $\begin{array}{l}\text { Reddish brown-grey silty clay containing occasional sand and gravel- } \\
\text { sized briquetage and charcoal; sharp to }\end{array}$ \\
\hline $\begin{array}{l}201.19- \\
201.18\end{array}$ & Reddish brown-grey sand; sharp to \\
\hline $\begin{array}{l}201.18- \\
201.03\end{array}$ & $\begin{array}{l}\text { Reddish brown-light grey mottled silt rich in blocky and gravel-sized } \\
\text { briquetage; occasional charcoal; gradual to }\end{array}$ \\
\hline $\begin{array}{l}201.03- \\
200.66\end{array}$ & $\begin{array}{l}\text { Reddish brown sandy gravely silt rich in charcoal and sand and gravel- } \\
\text { sized briquetage; blocky briquetage }(2 \mathrm{~cm}) \text { at base; common fine plant }\end{array}$ \\
\hline
\end{tabular}




\begin{tabular}{|l|l|}
\hline & remains \\
$199.66-$ & Wet slurry of blocky briquetage and charcoal in sandy silty matrix \\
\hline $199.66-$ & Dense unit of compact reddish orange briquetage; sharp to \\
199.34 & \\
\hline $\begin{array}{l}199.34- \\
199.04\end{array}$ & $\begin{array}{l}\text { Dark grey organic sandy gravely silt containing sparse plant matter and } \\
\text { woody remains; blocky briquetage at 199.07-199.04; blocky briquetage } \\
\text { also pushed into surface at 199.34-199.29 (not in-situ); occasional } \\
\text { charcoal from 199.34-199.12; gravel-sized briquetage between 199.22- } \\
199.12 ; \text { sharp to }\end{array}$ \\
\hline $\begin{array}{l}199.04- \\
199.02\end{array}$ & Light grey sand; sharp to \\
\hline $199.02-$ & $\begin{array}{l}\text { Continuation of } 199.34-199.04 ; \text { blocky briquetage at 198.99 and } \\
198.66\end{array}$ \\
\hline $\begin{array}{l}198.92-198.88 \\
198.05\end{array}$ & $\begin{array}{l}\text { Dark grey sandy silt rich in plant remains; sparse charcoal between } \\
198.66-198.23 ; \text { sharp to }\end{array}$ \\
\hline $\begin{array}{l}198.05- \\
198.02\end{array}$ & Dark grey silty sandy gravel; sharp to \\
\hline $\begin{array}{l}198.02- \\
197.91\end{array}$ & Continuation of 198.66-198.05; sharp to \\
\hline $\begin{array}{l}197.91- \\
197.66\end{array}$ & Grey sandy silty gravel \\
\hline
\end{tabular}

Table 14: BH104 (32N 324245, 5406425)

\begin{tabular}{|c|c|}
\hline $\begin{array}{l}\text { Elevation } \\
\text { (m a.s.I.) }\end{array}$ & Description \\
\hline $\begin{array}{l}202.10- \\
201.96\end{array}$ & $\begin{array}{l}\text { Brown dry stiff clay; modern roots; occasional sand-sized briquetage; } \\
\text { sharp to }\end{array}$ \\
\hline $\begin{array}{l}201.96- \\
201.66\end{array}$ & Blocky briquetage; contact obscured (probably sharp) \\
\hline $\begin{array}{l}201.66- \\
201.45\end{array}$ & $\begin{array}{l}\text { Greenish grey mottled stiff clay; occasional sand-sized briquetage and } \\
\text { fine plant matter; sharp to }\end{array}$ \\
\hline $\begin{array}{l}201.45- \\
201.38\end{array}$ & $\begin{array}{l}\text { Grey clay; rich in crumbling sand and gravel-sized and blocky } \\
\text { briquetage; common limestone nodules; limestone clast at } 201.40- \\
201.38 \text {; sharp to }\end{array}$ \\
\hline $\begin{array}{l}201.38- \\
201.26\end{array}$ & $\begin{array}{l}\text { Greenish grey silty clay; common sand and gravel-sized briquetage and } \\
\text { blocky briquetage; occasional charcoal; modern roots; gradual to }\end{array}$ \\
\hline $\begin{array}{l}201.26- \\
201.10\end{array}$ & Dark grey silt; rich in plant (Phragmites) remains \\
\hline $\begin{array}{l}201.10- \\
200.80\end{array}$ & $\begin{array}{l}\text { Brownish grey silt rich in laminated plant (Phragmites) remains; gradual } \\
\text { to }\end{array}$ \\
\hline $\begin{array}{l}200.80- \\
200.50\end{array}$ & Dark grey silty clay; common fine plant remains; gradual to \\
\hline $\begin{array}{l}200.50- \\
200.35\end{array}$ & $\begin{array}{l}\text { Dark grey dry crumbly silty clay; occasional sand and gravel-sized } \\
\text { briquetage; common fine plant remains and roots; shell beds and peaty } \\
\text { inclusions; sharp to }\end{array}$ \\
\hline $\begin{array}{l}200.35- \\
200.10\end{array}$ & Blocky briquetage; occasional charcoal and ash \\
\hline $\begin{array}{l}200.10- \\
199.87\end{array}$ & $\begin{array}{l}\text { Very wet slurry of brown sandy silt rich in sand and coarse gravel-sized } \\
\text { briquetage (up to } 3 \mathrm{~cm} \text { ); loose/unconsolidated; gradual to }\end{array}$ \\
\hline $\begin{array}{l}199.87- \\
199.10\end{array}$ & $\begin{array}{l}\text { Wet slurry of compact blocky briquetage in brown sandy silt; occasional } \\
\text { charcoal; large wood fragments at } 199.65-199.43 \text {; common fine plant }\end{array}$ \\
\hline
\end{tabular}




\begin{tabular}{|c|c|}
\hline & matter \\
\hline $\begin{array}{l}199.10- \\
198.89\end{array}$ & Blocky briquetage in wet brown sandy silty matrix; sharp to \\
\hline $\begin{array}{l}198.89- \\
198.54\end{array}$ & $\begin{array}{l}\text { Dark greyish brown sandy silt; rich in sand and coarse gravel-sized } \\
\text { briquetage; large horizontal charcoal fragment at } 198.85(5 \mathrm{~cm} \times 1 \mathrm{~cm}) \text {; } \\
\text { sharp to }\end{array}$ \\
\hline $\begin{array}{l}198.54- \\
198.53\end{array}$ & Blocky briquetage in wet brown sandy silty matrix \\
\hline $\begin{array}{l}198.53- \\
198.38\end{array}$ & $\begin{array}{l}\text { Dark greyish brown silty fine sandy gravel; rich in sand-sized } \\
\text { briquetage; horizontal bone shard at } 198.47(4 \mathrm{~cm} \times 3 \mathrm{~cm}) \text {; blocky } \\
\text { briquetage at 198.38; sharp to }\end{array}$ \\
\hline $\begin{array}{l}198.38- \\
198.29\end{array}$ & $\begin{array}{l}\text { Wet brown silty sandy gravel; horizontal wood fragment at } 198.38(6 \mathrm{~cm} \\
\text { x } 1 \mathrm{~cm}) \text {; common fine and coarse gravel-sized briquetage; common } \\
\text { small charcoal; sharp to }\end{array}$ \\
\hline $\begin{array}{l}198.29- \\
198.10\end{array}$ & $\begin{array}{l}\text { Grey sandy silty clay; occasional wood at 198.28; occasional sand and } \\
\text { gravel-sized briquetage throughout; blocky briquetage fragment in base }\end{array}$ \\
\hline $\begin{array}{l}198.10- \\
197.98\end{array}$ & $\begin{array}{l}\text { Dark grey fine sandy gravely silty clay; common whole and broken } \\
\text { Mollusca; occasional sand-sized briquetage; common fine plant } \\
\text { remains; gradual to }\end{array}$ \\
\hline $\begin{array}{l}197.98- \\
197.91\end{array}$ & $\begin{array}{l}\text { Dark grey silty clay; common Phragmites remains; occasional broken } \\
\text { shell; sharp to }\end{array}$ \\
\hline $\begin{array}{l}197.91- \\
197.86\end{array}$ & $\begin{array}{l}\text { Alternating horizons of yellow sand and dark grey-olive grey sandy silty } \\
\text { clay; gradual to }\end{array}$ \\
\hline $\begin{array}{l}197.86- \\
197.60\end{array}$ & $\begin{array}{l}\text { Olive greyish brown sandy silty clay; yellow sand inclusions; occasional } \\
\text { decomposed plant remains (peaty) and broken shell; gradual to }\end{array}$ \\
\hline $\begin{array}{l}197.60- \\
197.48\end{array}$ & $\begin{array}{l}\text { Banded dark grey and olive brown sandy silty clay; yellow sand } \\
\text { horizons; common laminated plant (Phragmites) remains; occasional } \\
\text { whole and broken Mollusca; sharp to }\end{array}$ \\
\hline $\begin{array}{l}197.48- \\
197.478\end{array}$ & Yellow sand; sharp to \\
\hline $\begin{array}{l}197.478- \\
197.47\end{array}$ & Yellowish brown sandy silty clay; sharp to \\
\hline $\begin{array}{l}197.47- \\
197.46\end{array}$ & Yellow sand; sharp to \\
\hline $\begin{array}{l}197.46- \\
197.33\end{array}$ & Olive grey sandy silt; common Mollusca and Phragmites; sharp to \\
\hline $\begin{array}{l}197.33- \\
197.30\end{array}$ & Dark olive grey silty clay; sharp to \\
\hline $\begin{array}{l}197.30- \\
197.24\end{array}$ & Dark greyish brown sandy silt; common Mollusca; sharp to \\
\hline $\begin{array}{l}197.24- \\
197.241\end{array}$ & Orange sand; sharp to \\
\hline $\begin{array}{l}197.241- \\
197.22\end{array}$ & Dark grey silty sand; sharp to \\
\hline $\begin{array}{l}197.22- \\
197.218 \\
\end{array}$ & Yellow sand containing Mollusca; sharp to \\
\hline $\begin{array}{l}197.218- \\
197.20\end{array}$ & Brownish grey silty clay; sharp to \\
\hline $\begin{array}{l}197.20- \\
197.10\end{array}$ & Wet grey sandy gravel \\
\hline
\end{tabular}

Table 15: BH105 (32N 324246, 5406446) 


\begin{tabular}{|c|c|}
\hline $\begin{array}{l}\text { Elevation } \\
\text { (m a.s.I) }\end{array}$ & Description \\
\hline $\begin{array}{l}201.97- \\
201.76\end{array}$ & $\begin{array}{l}\text { Dark brown stiff dry clay; modern roots; common sand and gravel-sized } \\
\text { briquetage; occasional small limestone clasts at 201.89-201.81; sharp } \\
\text { to }\end{array}$ \\
\hline $\begin{array}{l}201.76- \\
201.28\end{array}$ & $\begin{array}{l}\text { Blocky briquetage in dark brown dry stiff clay matrix; modern roots; } \\
\text { sharp to }\end{array}$ \\
\hline $\begin{array}{l}201.28- \\
201.19\end{array}$ & $\begin{array}{l}\text { Brownish grey silty clay; small charcoal and sand-sized briquetage; } \\
\text { faintly mottled; sharp to }\end{array}$ \\
\hline $\begin{array}{l}201.19- \\
201.16\end{array}$ & Continuation of 201.76-201.28; sharp to \\
\hline $\begin{array}{l}201.16- \\
201.01\end{array}$ & Reddish brown silty clay; fine plant remains; sharp to \\
\hline $\begin{array}{l}201.01- \\
200.89\end{array}$ & Blue-grey silt rich in Phragmites; common Mollusca; sharp to \\
\hline $\begin{array}{l}200.89- \\
200.24\end{array}$ & $\begin{array}{l}\text { Dark grey silt; mottled between } 200.89-200.83 \text { and } 200.70-200.65 ; \\
\text { sharp to }\end{array}$ \\
\hline $\begin{array}{l}200.24- \\
200.14\end{array}$ & $\begin{array}{l}\text { Blocky briquetage in dark brownish black silty sandy gravely matrix; } \\
\text { gradual to }\end{array}$ \\
\hline $\begin{array}{l}200.14- \\
199.97\end{array}$ & $\begin{array}{l}\text { Wet dark reddish brownish black silty sandy gravel; rich in charcoal and } \\
\text { sand and gravel-sized briquetage; blocky briquetage at base }\end{array}$ \\
\hline $\begin{array}{l}199.97- \\
199.48\end{array}$ & $\begin{array}{l}\text { Coarse gravel-sized briquetage and charcoal; loose/unconsolidated; } \\
\text { briquetage increasing in size towards base; sharp to }\end{array}$ \\
\hline $\begin{array}{l}199.48- \\
198.97\end{array}$ & $\begin{array}{l}\text { Wet slurry of blocky and gravel-sized briquetage and charcoal in } \\
\text { greyish brown sandy silty matrix }\end{array}$ \\
\hline $\begin{array}{l}198.97- \\
198.81\end{array}$ & $\begin{array}{l}\text { Compacted reddish brown blocky briquetage; occasional charcoal; } \\
\text { gradual to }\end{array}$ \\
\hline $\begin{array}{l}198.81- \\
198.68\end{array}$ & $\begin{array}{l}\text { Compacted dark reddish brown sandy silt; blocky briquetage; } \\
\text { occasional plant remains and charcoal; sharp to }\end{array}$ \\
\hline $\begin{array}{l}198.68- \\
198.61\end{array}$ & Compacted single piece of briquetage; sharp to \\
\hline $\begin{array}{l}198.61- \\
198.33\end{array}$ & $\begin{array}{l}\text { Compacted dark greyish brown sandy silt; common broken shell; } \\
\text { common gravel-sized and blocky briquetage; sharp to }\end{array}$ \\
\hline $\begin{array}{l}198.33- \\
198.20\end{array}$ & Compacted blocky briquetage (2 large pieces); charcoal; sharp to \\
\hline $\begin{array}{l}198.20- \\
197.97\end{array}$ & $\begin{array}{l}\text { Compacted dark grey silty sand; common broken shell; occasional sand } \\
\text { and gravel-sized briquetage; occasional charcoal (up to } 1 \mathrm{~cm} \times 0.2 \mathrm{~cm} \text { ); } \\
\text { occasional gravel towards base }\end{array}$ \\
\hline $\begin{array}{l}197.97- \\
197.74\end{array}$ & Light grey silty sand; contact obscured \\
\hline $\begin{array}{l}197.74- \\
197.45\end{array}$ & Dark grey silty sand; gradual to \\
\hline $\begin{array}{l}197.45- \\
197.13\end{array}$ & Very dark greyish black silty sand; sharp to \\
\hline $\begin{array}{l}197.13- \\
196.97\end{array}$ & Reddish brown sandy and gravel; gravel increasing in size to base \\
\hline
\end{tabular}

